\title{
Metallogenetic systems associated with granitoid magmatism in the Amazonian Craton: An overview of the present level of understanding and exploration significance
}

\author{
Jorge Silva Bettencourt ${ }^{a}{ }^{*}$, Caetano Juliani ${ }^{a}$, Roberto P. Xavier ${ }^{b}$, Lena V.S. Monteiro a \\ Artur C. Bastos Neto ${ }^{c}$, Evandro L. Klein ${ }^{\text {d, f }}$, Rafael R. Assis ${ }^{b}$, Washington Barbosa Leite Jr. ${ }^{\text {, }}$ \\ Carolina P.N. Moreto ${ }^{b}$, Carlos Marcello Dias Fernandes ${ }^{f}$, Vitor Paulo Pereira ${ }^{\mathrm{c}}$ \\ a Institute of Geoscience, University of São Paulo, Brazil \\ ${ }^{\mathrm{b}}$ Institute of Geoscience, University of Campinas, Brazil \\ ${ }^{\mathrm{c}}$ Institute of Geoscience, Federal University of Rio Grande do Sul, Brazil \\ d CPRM/Geological Survey of Brazil, Economic Geology Division, Brazil \\ e Institute of Geociences and Exact Sciences, São Paulo State University, Brazil \\ ${ }^{\mathrm{f}}$ Institute of Geoscience, Federal University of Pará, Brazil
}

\section{A R T I C L E I N F O}

\section{Article history:}

Received 1 July 2015

Received in revised form

18 November 2015

Accepted 22 November 2015

Available online 27 November 2015

\section{Keywords:}

Amazonian Craton

Granitoids

Precious

Rare and base-metals

\section{A B S T R A C T}

The Amazonian Craton hosts world-class metallogenic provinces with a wide range of styles of primary precious, rare, base metal, and placer deposits. This paper provides a synthesis of the geological database with regard to granitoid magmatic suites, spatio temporal distribution, tectonic settings, and the nature of selected mineral deposits. The Archean Carajás Mineral Province comprises greenstone belts (3.04 $-2.97 \mathrm{Ga})$, metavolcanic-sedimentary units $(2.76-2.74 \mathrm{Ga})$, granitoids $(3.07-2.84 \mathrm{Ga})$ formed in a magmatic arc and syn-collisional setting, post-orogenic $A_{2}$-type granites as well as gabbros (ca. $2.74 \mathrm{Ga}$ ), and anorogenic granites $(1.88 \mathrm{Ga}$ ). Archean iron oxide-Cu-Au (IOCG) deposits were synchronous or later than bimodal magmatism $(2.74-2.70 \mathrm{Ga})$. Paleoproterozoic IOCG deposits, emplaced at shallow-crustal levels, are enriched with $\mathrm{Nb}-\mathrm{Y}-\mathrm{Sn}-\mathrm{Be}-\mathrm{U}$. The latter, as well as $\mathrm{Sn}-\mathrm{W}$ and Au-EGP deposits are coeval with ca. 1.88 Ga $\mathrm{A}_{2}$-type granites. The Tapajós Mineral Province includes a low-grade meta-volcano-sedimentary sequence $(2.01 \mathrm{Ga})$, tonalites to granites $(2.0-1.87 \mathrm{Ga})$, two calc-alkaline volcanic sequences $(2.0-1.95 \mathrm{Ga}$ to $1.89-1.87 \mathrm{Ga}$ ) and A-type rhyolites and granites (1.88 Ga). The calc-alkaline volcanic rocks host epithermal $\mathrm{Au}$ and base metal mineralization, whereas $\mathrm{Cu}-\mathrm{Au}$ and $\mathrm{Cu}-\mathrm{Mo} \pm \mathrm{Au}$ porphyry-type mineralization is associated with sub-volcanic felsic rocks, formed in two continental magmatic arcs related to an accretionary event, resulting from an Andean-type northwards subduction. The Alta Floresta Gold Province consists of Paleoproterozoic plutono-volcanic sequences $(1.98-1.75 \mathrm{Ga})$, generated in ocean-ocean orogenies. Disseminated and vein-type $\mathrm{Au} \pm \mathrm{Cu}$ and $\mathrm{Au}+$ base metal deposits are hosted by calc-alkaline I-type granitic intrusions ( $1.98 \mathrm{Ga}, 1.90 \mathrm{Ga}$, and $1.87 \mathrm{Ga}$ ) and quartz-feldspar porphyries (ca. $1.77 \mathrm{Ga}$ ). Timing of the gold deposits has been constrained between $1.78 \mathrm{Ga}$ and $1.77 \mathrm{Ga}$ and linked to post-collisional Juruena arc felsic magmatism (e.g., Colíder and Teles Pires suites). The Transamazonas Province corresponds to a N-S-trending orogenic belt, consolidated during the Transamazonian cycle (2.26-1.95 Ga), comprising the Lourenço, Amapá, Carecuru, Bacajá, and Santana do Araguaia tectonic domains. They show a protracted tectonic evolution, and are host to the pre-, syn-, and post-orogenic to anorogenic granitic magmatism. Gold mineralization associated with magmatic events is still unclear. Greisen and pegmatite $\mathrm{Sn}-\mathrm{Nb}-\mathrm{Ta}$ deposits are related to 1.84 to $1.75 \mathrm{Ga}$ late-orogenic to anorogenic A-type granites. The Pitinga Tin Province includes the Madeira Sn-Nb-Ta-F deposit, Sngreisens and Sn-episyenites. These are associated with A-type granites of the Madeira Suite (1.84 $-1.82 \mathrm{Ga}$ ), which occur within a cauldron complex (Iricoumé Group). The A-type magmatism evolved from a post-collisional extension, towards a within-plate setting. The hydrothermal processes $\left(400{ }^{\circ} \mathrm{C}\right.$ $-100^{\circ} \mathrm{C}$ ) resulted in albitization and formation of disseminated cryolite, pyrochlore columbitization, and formation of a massive cryolite deposit in the core of the Madeira deposit. The Rondonnia Tin Province hosts rare-metal ( $\mathrm{Ta}, \mathrm{Nb}, \mathrm{Be})$ and $\mathrm{Sn}-\mathrm{W}$ mineralization, which is associated with the São Lourenço-

\footnotetext{
* Corresponding author.
} 
Caripunas (1.31-1.30 Ga), related to the post-collisional stage of the Rondônia San Ignácio Province (1.56 $-1.30 \mathrm{Ga})$, and to the Santa Clara $(1.08-1.07 \mathrm{Ga})$ and Younger Granites of Rondônia $(0.99-0.97 \mathrm{Ga}) \mathrm{A}$ type granites. The latter are linked to the evolution of the Sunsás-Aguapeí Province (1.20-0.95 Ga). Raremetal polymetallic deposits are associated with late stage peraluminous granites, mainly as greisen, quartz vein, and pegmatite types.

๑) 2015 Elsevier Ltd. All rights reserved.

\section{Introduction}

A great diversity of world-class precious, rare and base metal deposits associated with granitoids has been identified in the Amazonian Craton (AC) during the last twenty five years.

Prior to the 1960's, very few gold occurrences were known in the $\mathrm{AC}$ and there was little understanding of the potential for precious, base and rare-metal mineralization. This perception has changed since the 1990's, in response to gold demand. Extensive research has led to a range of convincing genetic models and technical developments in the exploration of primary iron oxide-copper-gold (IOCG), intrusion-related (IR-non skarn), orogenic gold mineralization types and epithermal and porphyry gold systems.

The largest gold, copper-gold and base-metal deposits are found within the Archean Carajás Province, Proterozoic Tapajós and Alta Floresta provinces. The most important rare-metal deposits are present in the Rondônia and Pitinga tin provinces.

The magmatic history of the granitoids and their associated mineralization systems in the AC is far from being fully understood. Many fundamental questions still require answers before a serious attempt to elucidate them can be satisfactorily undertaken. As such, there is a clear demand for better constraints the timing of the mineralization with regard to tectonic, magmatism, source components, and fluid environments, since the majority of the deposits are not well documented and the tectonic setting for the terranes remains controversial.

This paper provides a general overview of selected rare, precious, and base metal deposits in the AC (Brazilian territory), temporally and spatially associated with granitoid rocks, aiming to better constrain their genetic and corresponding exploration models. We have attempted to synthesize and interpret the more recent updates of the existing database in relation to their tectonic setting, associated granitoid rocks, distribution, major geological characteristics, mineralization style, fluid evolution, and genetic types.

\section{Components of the Amazonian Craton}

The AC was formerly considered by Amaral (1974) and Almeida et al. (1981) as a large Archean platform, partially reworked and reactivated during the Proterozoic, resulting in intense anorogenic felsic magmatism. However, the zonation of $\mathrm{K}-\mathrm{Ar}$ ages allowed Cordani et al. (1979) to envisage an evolution of AC by sequential accretion and collision of juvenile terranes around an Archean nucleus. The continuous acquisition of geochronological data $(\mathrm{Rb}-\mathrm{Sr}$ and $\mathrm{U}-\mathrm{Pb})$ indicates that the AC grew through continued Proterozoic soft-collision/accretionary processes driven by northeasterly B-type subductions, surrounding an Archean core (Fig. 1; Teixeira et al., 1989; Tassinari and Macambira, 2004; Cordani and Teixeira, 2007). These works resulted in the subdivision of $A C$ into two Archean nuclei and five Proterozoic geotectonic provinces. The same tectonic structure was reinforced, with modifications of some provinces by Santos et al. (2000) and Santos (2003), based on $\mathrm{U}-\mathrm{Pb}$ SHRIMP zircon and TIMS data from a few hundred samples, as well as $\mathrm{Pb}-\mathrm{Pb}$ evaporation (Fig. 2).
More recently, Fernandes et al. (2011) and Juliani et al. (2013, 2014) have demonstrated the absence of island arc terranes, metamorphism and deformation correlated to collisional processes in the Central Amazon and Ventuari-Tapajós (or Tapajós-Parima) provinces. The new data, largely based on field work, geochemistry, geophysical studies and isotope geology indicate that the southern part of AC is essentially composed of two continental magmatic arcs that evolved between ca. 2.0 and $1.86 \mathrm{Ga}$, named Tapajonic Arcs, with a possible flat subduction stage, under an ArcheanPaleoproterozoic continent. In this model, E-W structures approximately parallel to the trench of a northward subduction zone would control the emplacement of different calc-alkaline magma and volcanism. The magmatic arcs were, at least in part, overlapped (Juliani and Fernandes, 2010; Juliani et al., 2013). In these arcs, the magmatic zonation towards the back-arc appears to result in metallogenetic zoning of precious and base metal magmatic-hydrothermal occurrences.

\section{Carajás Province}

The Carajás Province (Santos et al., 2000) represents an Archean crustal nucleus located in the eastern part of the Amazon Craton. It was divided into two tectonic domains: Rio Maria in the south and Carajás in the north (Vasquez et al., 2008b).

The Rio Maria Domain represents a typical granite-greenstone terrane and encompasses ca. 3.04 to 2.97 Ga greenstone belts grouped in the Andorinhas Supergroup (Souza et al., 2001) and granitoids. The latter comprises TTG emplaced at 2.98 to $2.92 \mathrm{Ga}$ and $2.96 \mathrm{Ga}$, sanukitoid $(2.87 \mathrm{Ga}$ ) and granite suites, including potassic leucogranite, leucogranodiorite-granite, and amphibolebiotite monzogranite (ca. 2.87-2.86 Ga; Oliveira et al., 2009, 2011, Almeida et al., 2011, 2013). According to Souza et al. (2001), ca. $2.86 \mathrm{Ga}$ shear zones resulted from the last deformational event identified in this domain. After that, the Rio Maria Domain remained stable until the emplacement of the $1.88 \mathrm{Ga} \mathrm{A}_{2}$-type granites and associated dikes (Dall'Agnol et al., 1999, 2005).

The Carajás Domain (Fig. 3) encompasses rocks of the Mesoarchean age, which are mostly part of its basement, Neoarchean volcano-sedimentary sequences, named the Carajás Basin, and coeval, widespread, granite magmatism.

The Mesoarchean units include greenstone belts (ca. $2.97 \mathrm{Ga}$; Moreto et al., 2015), TTG-like orthogneisses and migmatites (e.g. ca. 3.06 Ga Xingu Complex; Delinardo da Silva, 2014), and mafic and felsic granulites (e.g. 3.0 Ga Pium Complex; Pidgeon et al., 2000; renamed as Chicrim-Cateté Orthogranulite; Vasquez et al., 2008b), and granitoids. Orthogneisses and granulites underwent medium to high-grade metamorphism at ca. 2.96 Ga (Delinardo da Silva, 2014) and ca. 2.86 Ga (Machado et al., 1991; Pidgeon et al., 2000), coeval with major granitogenesis events during the Mesoarchean in the Carajás Province. Mesoarchean granitoids are represented by calc-alkaline tonalite-granodiorites (ca. 3.00 Ga; Moreto et al., 2011, 2015a,b) and granites (ca. $2.96 \mathrm{Ga}$ and ca. 2.87-2.83 Ga; Moreto et al., 2011; Feio et al., 2013), formed in magmatic arc and syncollisional setting.

The Neoarchean Carajás Basin was infilled by volcano- 


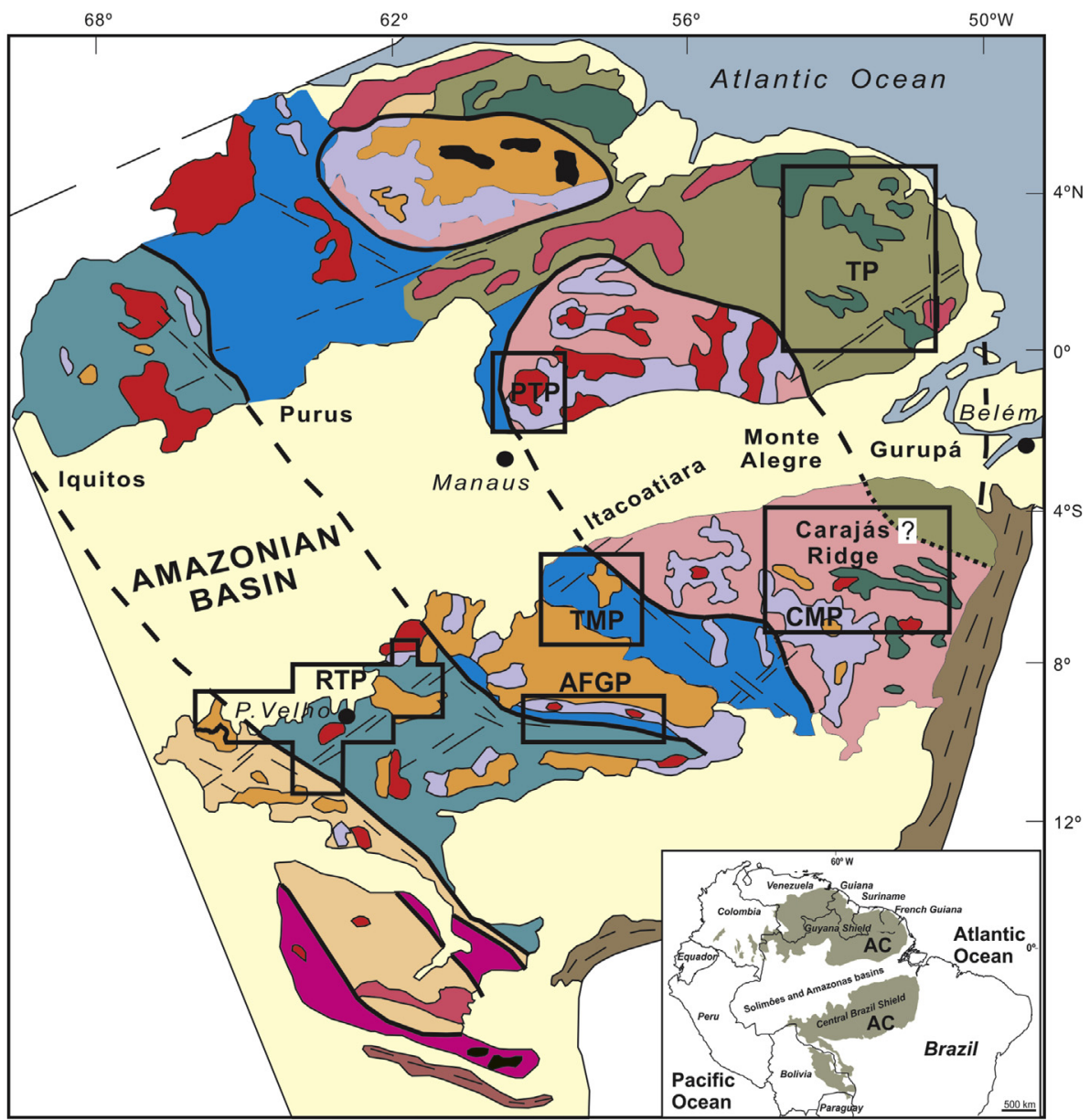

\section{TECTONIC PROVINCES}

Central Amazonian $(>2.3 \mathrm{Ga})$

\begin{tabular}{|l}
\hline $\begin{array}{l}\text { Maroni- Itacaiúnas } \\
(2.2-1.9 \mathrm{Ga})\end{array}$ \\
$\begin{array}{l}\text { Ventuari-Tapajós } \\
(1.9-1.8 \mathrm{Ga})\end{array}$ \\
Rio Negro - Juruena \\
$(1.8-1.55 \mathrm{Ga})$ \\
$\begin{array}{l}\text { Rondonian - San Ignácio } \\
(1.5-1.3 \mathrm{Ga})\end{array}$ \\
Sunsás $(1.25-1.0 \mathrm{Ga})$
\end{tabular}

GEOLOGICAL UNITS

Phanerozoic Covers

Granitoids

Precambrian Sedimentary Covers

Acid - Intermediate Volcanic Covers

Basic Volcanic Rocks

Greenstone Belts

Granulitic Complex

Neoproterozoic Mobile Belt

- Basement Structural High

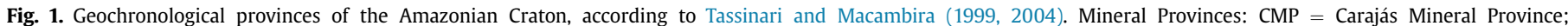
TMP = Tapajós Mineral Province; AFGP = Alta Floresta Gold Province; TP = Transamazonas Province; PTP = Pitinga Tin Province; RTP = Rondônia Tin Province.

sedimentary units (e.g. ca. 2.76 to 2.73 Ga Itacaiúnas Supergroup and Rio Novo Group; Hirata et al., 1982; Wirth et al., 1986; DOCEGEO, 1988; Machado et al., 1991). These units include basalts, basaltic andesite, rhyolite, tuffs, banded iron formations, and sedimentary units, metamorphosed in greenschist to amphibolite facies (DOCEGEO, 1988). The Águas Claras Formation (Nogueira et al., 1995) overlaid the volcano-sedimentary sequences and comprises an alternating sequence of low-grade metamorphosed sandstone, siltstone and pelite, deposited in a fluvial to shallow marine environment (Nogueira et al., 1995).

Mafic-ultramafic layered complexes (e.g., Luanga, $2763 \pm 6 \mathrm{Ma}$,
U-Pb zircon; Machado et al., 1991) and ca. 2.75 to 2.73 Ga norites, gabbronorites, quartz gabbros, and enderbites (e.g. Pium Diopside Norite; Vasquez et al., 2008b) have been temporally associated with extensional events responsible for the development of the riftrelated Carajás Basin (Santos et al., 2013).

Neoarchean syntectonic foliated alkaline and metaluminous $\mathrm{A}_{2}$ type granites (ca. 2.75 Ga to $2.70 \mathrm{Ga}$; Barros et al., 2009; Sardinha et al., 2006; Feio et al., 2012, 2013) were previously emplaced or synchronous to the basin inversion. The latter was attributed to shortening from NNE to SSW, resulting in regional E-W and ESE-WNW shear zones and NE-SW strike-slip faults developed in 


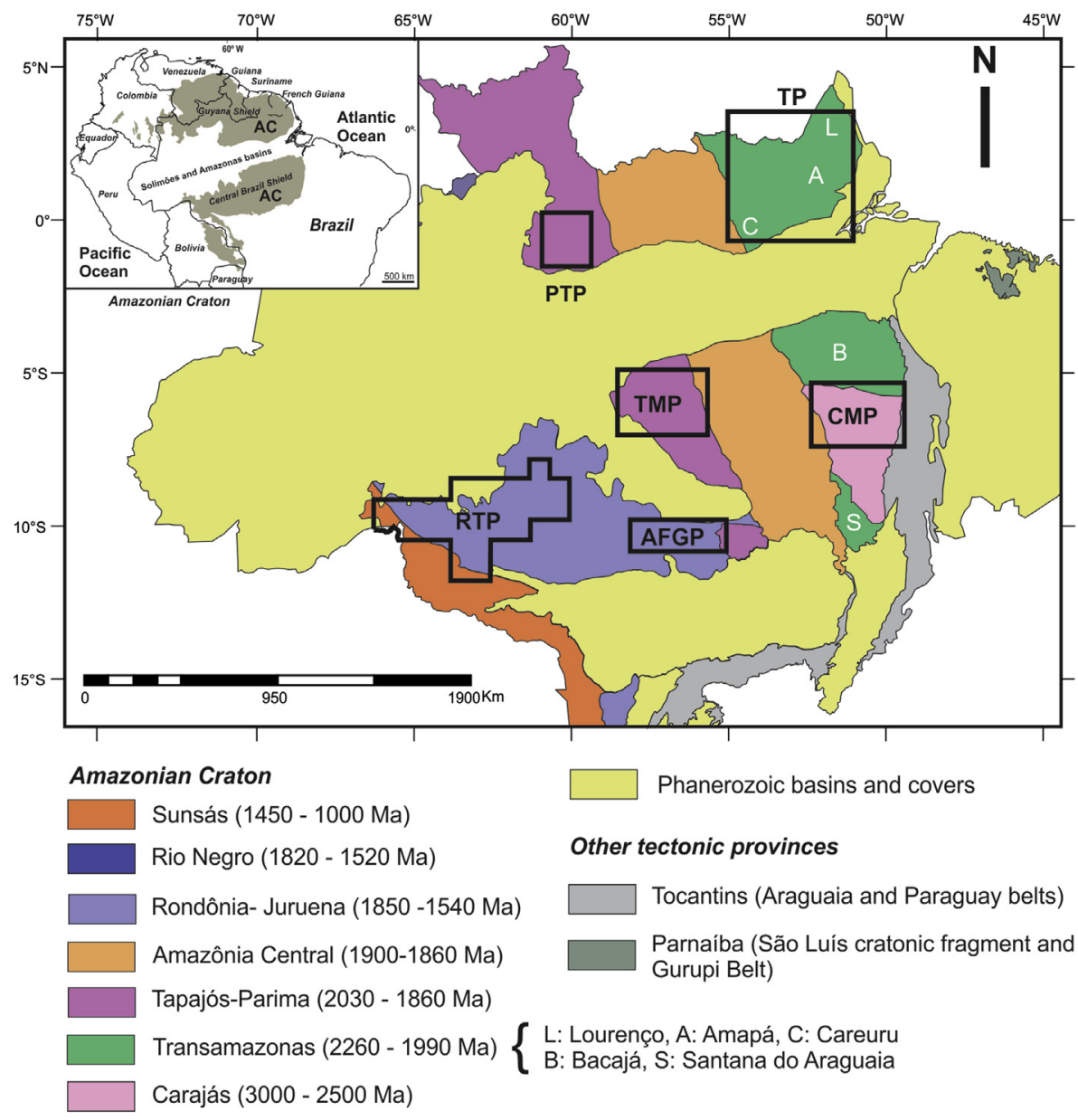

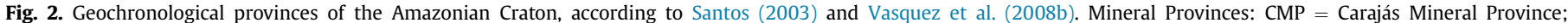
$\mathrm{TMP}=$ Tapajós Mineral Province; AFGP = Alta Floresta Gold Province; TP = Transamazonas Province; PTP $=$ Pitinga Tin Province; RTP = Rondônia Tin Province.

ductile-brittle conditions (Pinheiro et al., 2013).

Minor occurrences of ca. $2.57 \mathrm{Ga}$ alkaline, peralkaline to metaluminous granites have also been recognized within the regional shear zones in the northern boundary of the Carajás Domain (e.g. Old Salobo granite; Machado et al., 1991). Similar to the Rio Maria Domain, the ca. $1.88 \mathrm{Ga} \mathrm{A}_{2}$-type granites also extend throughout the Carajás Domain (Machado et al., 1991; Tallarico et al., 2004). Other magmatic events represented by late undeformed diabase dikes of uncertain ages were recognized in this domain.

\subsection{Mineral systems and deposits associated with granitoids in the Carajás Province}

The Carajás province is notable for its metallogenic diversity and comprises several mineral deposit types spatially and/or temporally related to granitoids, in particular iron oxide-copper-gold, polymetallic copper-gold, tungsten, tin, and gold-EGP deposits.

In the Rio Maria Domain, orogenic gold (Oliveira and Leonardos, 1990; Huhn, 1992; Santos et al., 1998; Villas and Santos, 2001) and tungsten deposits (e.g. Pedra Preta; Rios et al., 1988, 2003) have been identified. The orogenic gold deposits (e.g. Diadema, Lagoa Seca, Babaçu, Mamão, Tucumã, Inajá, Cuca, Cumaru) are characterized by structurally-controlled quartz veins within regional shear zones, which crosscut the ca. 3.04 to 2.97 greenstone belt sequences and granitoids (Oliveira and Leonardos, 1990; Huhn, 1992; Santos et al., 1998; Villas and Santos, 2001; Oliveira and Santos, 2003). Hydrothermal alteration comprises chlorite-carbonate-albite-muscovite; chlorite-sericite; quartz-pyrite; and tourmaline-quartz assemblages (Oliveira, 1993). Gold is associated with magnetite, ilmenite, pyrite, chalcopyrite, pyrrhotite, and bismuthinite. In addition to aqueous-carbonic $\left(\mathrm{H}_{2} \mathrm{O}-\mathrm{CO}_{2}-\mathrm{NaCl}\right)$ and carbonic fluids of metamorphic origin, a contribution of magmatic aqueous fluids $\left(\mathrm{H}_{2} \mathrm{O}-\mathrm{NaCl}-\mathrm{KCl}-\mathrm{CaCl}_{2}\right)$ was identified in the ca. 2.82 Ga Cumaru granitoid-hosted gold deposit (Santos et al., 1998).

The Pedra Preta tungsten deposit $(508,300$ tones at $1.01 \%$ of $\mathrm{WO}_{3}$; Cordeiro et al., 1988) is hosted by the ca. 1.88 Ga $\mathrm{A}_{2}$-type oxidized Musa granite (Dall'Agnol and Oliveira, 2007) and greenstone belt units. Tungsten lode ore occurs as hydrothermal veins (quartz-

-wolframite-topaz-fluorite-mica-pyrite-pyrrhotite-chalcopyrite-molybdenite-bismuthinite) that intercept greisen zones within the Musa granite cupola and the country rocks (Rios, 1995; Rios et al., 2003). Fluid inclusion and stable isotope data provide evidence of mixing between strongly reduced externally-derived fluids $\left(\mathrm{H}_{2} \mathrm{O}+\mathrm{CH}_{4}+\right.$ salt $\left.\pm \mathrm{CO}_{2}\right)$ and oxidized hypersaline fluids (>330 ${ }^{\circ} \mathrm{C} ; 42 \mathrm{wt} \% \mathrm{CaCl}_{2}$ eq.) of magmatic origin (Rios et al., 2003).

In the Carajás Domain (Fig. 3), world-class iron oxide-coppergold (IOCG) deposits (e.g. Salobo, Sequeirinho, Sossego, Cristalino, Alvo 118, Igarapé Bahia/Alemão) have resources of more than 2 billion tons at $0.77-1.4 \mathrm{wt}$. \% $\mathrm{Cu}$ and $0.28-0.86 \mathrm{~g} / \mathrm{t} \mathrm{Au}$ (Xavier et al., 2012). These IOCG deposits are located within regional $E-W$ and ESE-WNW shear zones and NE-SW strike-slip faults and represent multiple hydrothermal events (ca. 2.70-2.68 Ga; ca. 2.57-2.42 


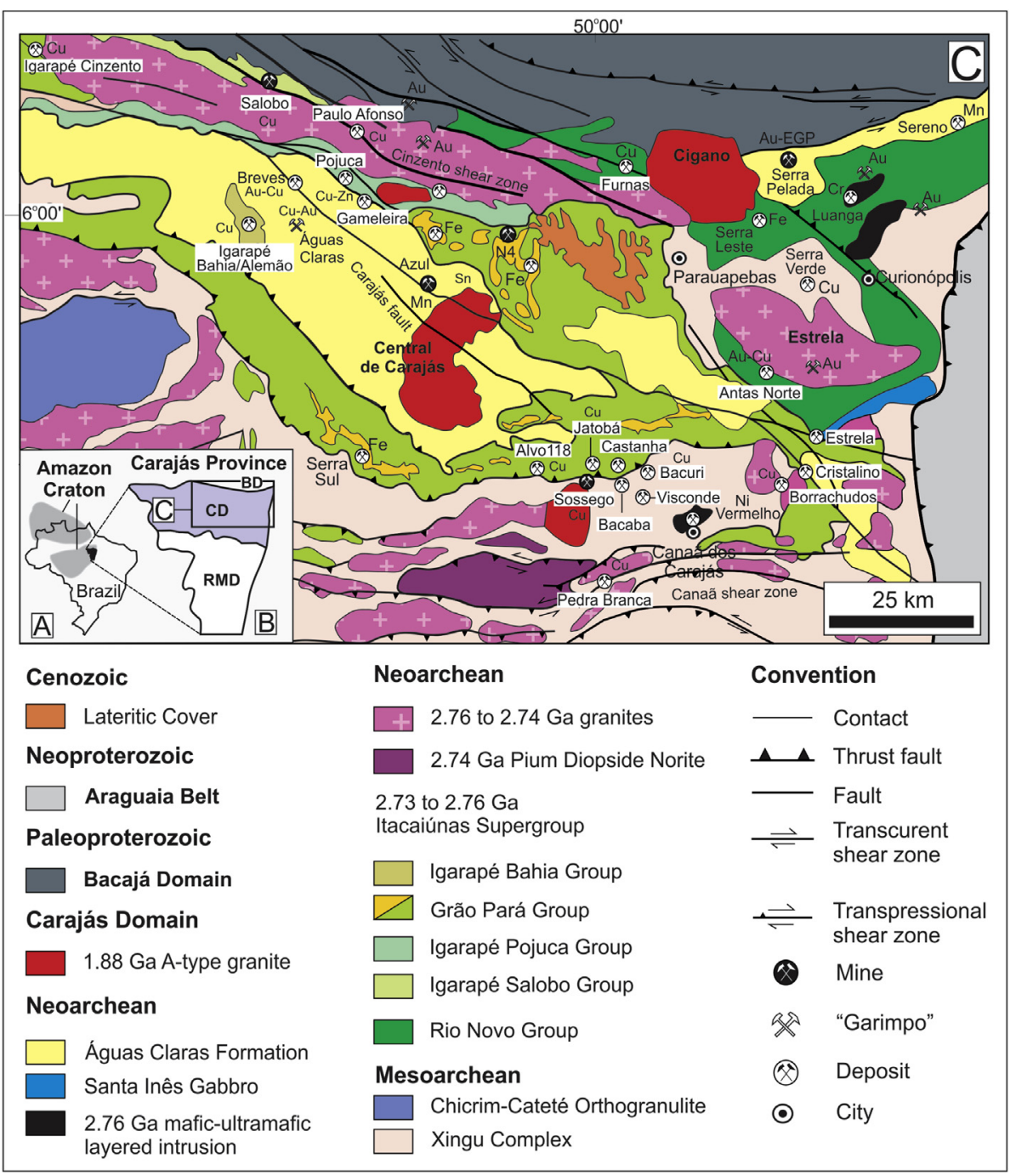

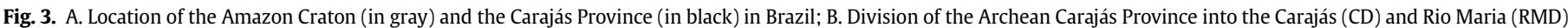

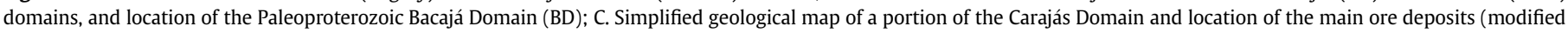
from DOCEGEO, 1988; Vasquez et al., 2008b).

Ga, and ca. 1.88 Ga; Réquia et al., 2003; Tallarico et al., 2005; Melo, 2014; Moreto et al., 2015a, 2015b).

Ca. 2.7 Ga IOCG deposits have been recognized in the southern limit of the Carajás basin. The Sequeirinho ore body at the Sossego $\mathrm{Cu}-\mathrm{Au}$ mine is their main representative (Monteiro et al., 2008a, 2008b; Moreto et al., 2015a, 2015b). These deposits are hosted both by Mesoarchean greenstone belt rocks and granitoids, which are crosscut by ca. 2.74 Ga ferroan, calc-alkalic to alkali-calcic, metaluminous granites and related gabbronorites. Coeval postorogenic $\mathrm{A}_{2}$-type (e.g. Sossego Granophyric Granite; Y/Nb > 1; Sc/ $\mathrm{Nb}<2 ; \mathrm{Rb} / \mathrm{Nb}<15$ ) and anorogenic (e.g. Curral) granites likely reflect a transition from an extension of thickened arc crust to a rift setting during the Neoarchean.

Extensive albite-(actinolite) alteration zones and associated magnetite-(apatite) bodies crosscut by chalcopyrite-rich breccias are ubiquitous features of these deposits (Fig. 4). Their ore geochemical signature is marked by anomalous concentrations of Fe-LREE-Mo-Ni-Co-Pd. Contents of [( $\left.\left.\mathrm{Nb}^{*} 10\right)-\left(\mathrm{TiO}_{2}{ }^{*} 100\right)-\mathrm{Zr}\right]$ ore samples indicate strong inheritance of host rocks in the Archean deposits (e.g. $2.74 \mathrm{Ga}$ gabbros in the $2.7 \mathrm{Ga}$ Sequeirinho ore body). These IOCG deposits have likely been formed by mixing between magmatic-derived $\left(\delta^{18} \mathrm{O}_{\text {fluid }}=6.0-7.8 \%\right.$ at $550{ }^{\circ} \mathrm{C}$; Monteiro et al., 2008a) and external fluids. However, extensive fluid-rock interaction involving Mesoarchean and Neoarchean units (e.g. metaultramafic, mafic and granitic rocks) may have played an important role in the genesis of these deposits.

Ca. 2.57-2.42 Ga IOCG deposits (e.g. Salobo, Réquia et al., 2003; Igarapé Bahia, Tallarico et al., 2005) have been defined particularly in the northern limit of the Carajás Basin within the domains of the regional-scale Cinzento shear zone. These deposits are commonly hosted by hydrothermally-altered gneisses (2.96 Ga), Neoarchean metavolcanic-sedimentary units, and ca. $2.74 \mathrm{Ga}$ and $2.57 \mathrm{Ga}$ deformed metaluminous granites (Tallarico et al., 2005; Melo, 2014). High-temperature magnetite-almandine-grunerite-biotite alteration zones envelop lens-shaped and massive chalcocite-bornite-chalcopyrite-rich ore bodies in the Salobo deposit. Magnetite-chalcopyrite-rich breccia ore bodies, on the other hand, are associated with strong chlorite-carbonate-actinolite-biotite alteration in the Igarapé Bahia IOCG deposit (Tallarico et al., 2005).

Additionally, a diversified group of mineral deposits is also related to ca. $1.88 \mathrm{Ga} \mathrm{A}_{2}$-type granites and quartz porphyries (Tallarico, 2003; Moreto et al., 2015a). Paleoproterozoic IOCG deposits (e.g. Alvo 118; Sossego ore body in the Sossego Cu-Au mine) have well-developed potassic and chloritic alteration zones (Fig. 4), 


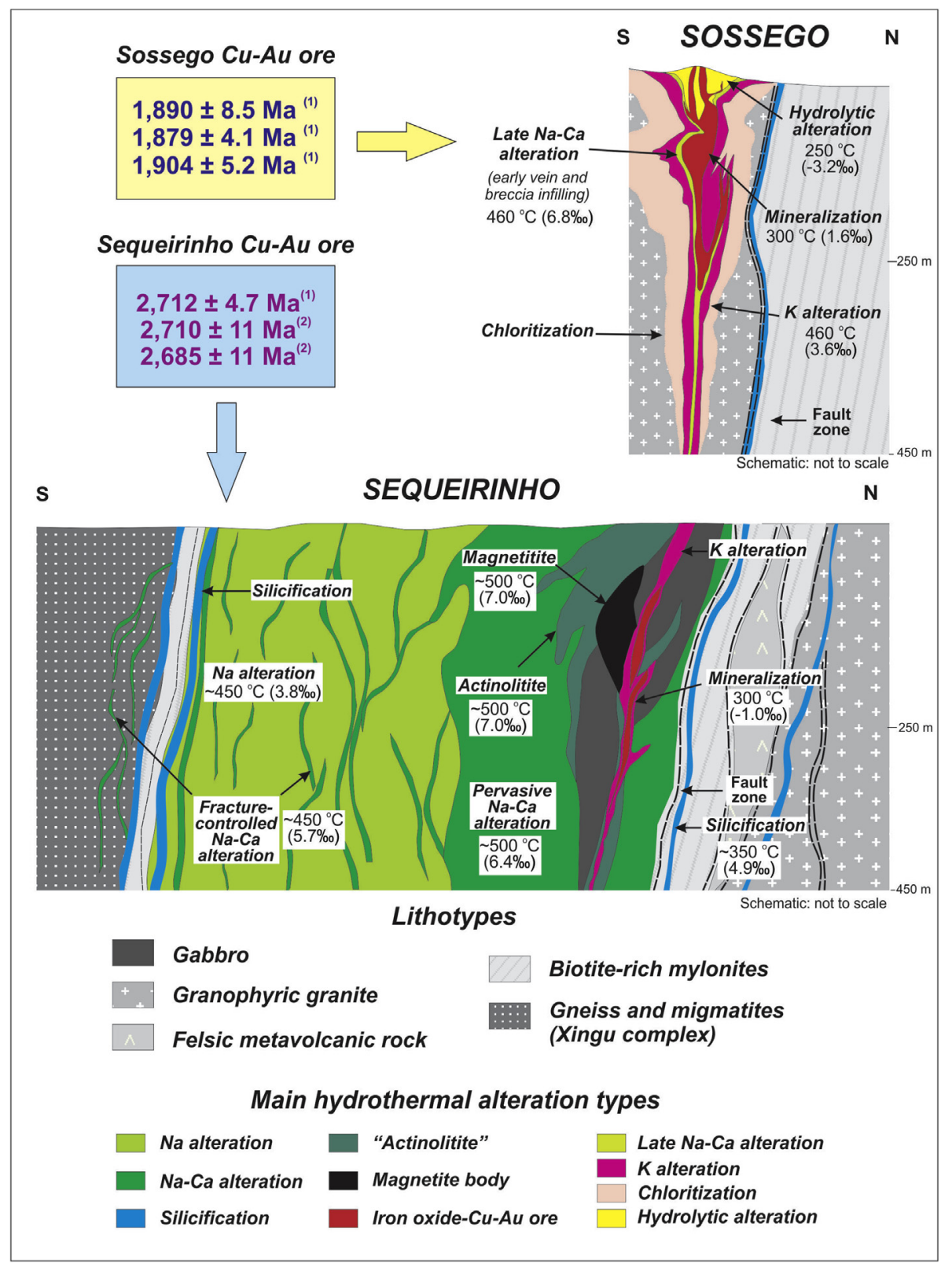

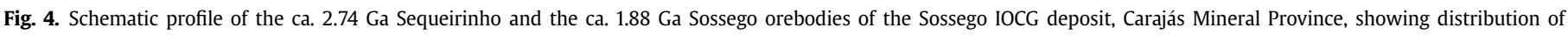

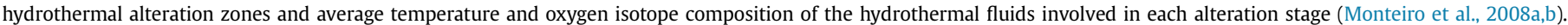
Geochronological data: Moreto et al. (2015a,b): (1) U-Pb LA-MC-ICPMS in monazite; (2) Re-Os in molybdenite.

elevated $\mathrm{U}-\mathrm{Au}$ and $\mathrm{Nb}-\mathrm{Sn}-\mathrm{Y}-\mathrm{Bi}-\mathrm{Be}-\mathrm{HREE}$ contents, as well as evidence for $\mathrm{F}$ metasomatism. These deposits reveal a major contribution of surface-derived fluids $\left(\delta^{18} \mathrm{O}_{\text {fluid }}=-0.4\right.$ to $-5.2 \%$ at $\left.300{ }^{\circ} \mathrm{C}\right)$ and oxidized sulfur (sulfate) source $\left(\delta^{34} \mathrm{~S}_{\mathrm{cpy}}>7.5 \%\right.$; Torresi et al., 2012; Monteiro et al., 2008a).

A polymetallic signature (e.g. $\mathrm{Cu}-\mathrm{Au}-\mathrm{W}-\mathrm{Bi}-\mathrm{Mo}-\mathrm{Sn}$; Breves deposit; Tallarico et al., 2004; Xavier et al., 2005, Botelho et al., 2005; $\mathrm{Cu}-\mathrm{Au}-\mathrm{Li}-\mathrm{Be}-\mathrm{Sn}-\mathrm{W}$; Estrela deposit; Lindenmayer et al., 2005) is also characteristic of iron-oxide-poor $\mathrm{Cu}-\mathrm{Au}$ deposits (e.g. Estrela, Breves, Águas Claras). The Estrela deposit is hosted by metavolcanic rocks of the Itacaiúnas Supergroup and is spatially related to an alkaline and peraluminous albite-ortoclase granite $(1.881 \pm 5 \mathrm{Ma}$; $\mathrm{U}-\mathrm{Pb}$ zircon; Lindenmayer et al., 2005). Intense pervasive potassic alteration (biotite-syderophyllite-tourmaline-titanite-fluoritequartz-magnetite-uraninite) was followed by copper-gold mineralization and late greisenization (Li-muscovite, zinnwaldite, tourmaline, quartz, fluorite, topaz, and chlorite). Veins and breccias infilled by chalcopyrite, gold, Co-pyrite, Ni-pyrite, Ni-pyrrhotite, molybdenite and bornite comprise the bulk of the copper-gold ore (Lindenmayer et al., 2005).

Highly variable salinities (1-50 wt.\% $\mathrm{NaCl}$ eq.) and homogenization temperatures $\left(80-480{ }^{\circ} \mathrm{C}\right.$; potassic alteration; $130-430{ }^{\circ} \mathrm{C}$; greisenization) have been estimated from fluid inclusions (Lindenmayer et al., 2005). A contribution of magmatic components in the system is suggested by stable isotope data $\left(\delta^{18} \mathrm{O}_{\mathrm{H}_{2} \mathrm{O}}=5.3 \%\right.$; potassic alteration; $\left.\delta^{34} \mathrm{~S}_{\text {sulfides }}=0.6-4.1 \%\right)$. However, Re-Os molybdenite (ca. $2.7 \mathrm{Ga}$ ) and $\mathrm{Sm}-\mathrm{Nd}$ isochron $\left(1857 \pm 98 \mathrm{Ma} ; \varepsilon \mathrm{Nd}_{(\mathrm{T})}=-10.7\right)$ ages have been obtained from the same mineralized vein (Lindenmayer et al., 2005), pointing to a complex evolution with multiple events.

In addition, Sn mineralization is also spatially associated with greisen zones within 1.88 Ga granite cupola (e.g. Central de Carajás 
Granite; Velho Guilherme Intrusive Suite). The latter, located in the western portion of the Carajás Province, comprises subalkaline, metaluminous to peraluminous, syenogranite to monzogranite with a geochemical affinity of within-plate $\mathrm{A}_{2}$-type granites (1867 Ma, $1862 \mathrm{Ma}$, and $1866 \mathrm{Ma}$; Pb-Pb zircon ages; Teixeira et al., 2002a).

The tin mineralized granites are silica-rich $\left(\mathrm{SiO}_{2}>75 \%\right)$, strongly enriched with LREE and evolved. These granites have Nd model ages (Velho Guilherme $=3.0$ to $3.2 \mathrm{Ga}$; Central de Carajás $=3.4$ to $2.6 \mathrm{Ga})$ and negative initial $\varepsilon \mathrm{Nd}_{(1880 \mathrm{Ma})}$ values $(-7.9$ to -12.2 ; Velho Guilherme; -7.9 to -10.5 ; Central de Carajás), indicating magma sources derived mainly from Mesoarchean rocks with a long crustal residence time (Teixeira et al., 2002a; Dall'Agnol et al., 2005).

Interaction with F-enriched fluids during late- and postmagmatic alteration resulted in secondary assemblages with albite, sericite, muscovite, chlorite, fluorite, epidote, topaz, carbonate, K-feldspar, allanite, monazite, fluocerite, and yttrocerite. Greisens (siderophyllite-chlorite-muscovite-quartz) and argillic alteration have been also identified. Cassiterite, associated with muscovite and chlorite, was formed from oxidation of the Snbearing iron-micas (Teixeira et al., 2002b). Fluid inclusion studies point to participation of diluted and highly saline fluids at decreasing temperatures from greisen formation (up to $396.6^{\circ} \mathrm{C}$ ) to the argillic stage $\left(123.8^{\circ} \mathrm{C}-95.6{ }^{\circ} \mathrm{C}\right)$.

$\mathrm{U}-\mathrm{Pb}$ monazite $(1.861 \pm 45 \mathrm{Ma})$ and $\mathrm{Ar}-\mathrm{Ar}$ biotite ages $(1.882 \pm 3 \mathrm{Ma})$ have also been reported for the Serra Pelada Au-EGP deposit (Grainger et al., 2008), which is hosted by the Águas Claras Formation metasedimentary sequence, close to the Cigano A-type granite (1883 $\pm 2 \mathrm{Ma}, \mathrm{U}-\mathrm{Pb}$ zircon, Machado et al., 1991).

\section{Tapajós Mineral Province}

The Tapajós Mineral Province is a large gold panning production area ( $>650$ t to the present) located between the Ventuari-Tapajós (or Tapajós-Parima; 2.03-1.88 Ga; Fig. 2) and Central Amazonian provinces (Fig. 1). It was formed through the evolution of oceancontinent orogenies, between 2.10 and $1.87 \mathrm{Ga}$.

The Tapajós-Parima Province is essentially composed of a ca. 2.1 Ga volcano-sedimentary sequence (Jacareacanga Group) and the magmatic arcs of the Cuiú-Cuiú Complex (ca. 2.01 Ga), Creporizão Intrusive Suite (1.97-1.95 Ga), Rio das Tropas Tonalite (ca. $1.90 \mathrm{Ga}$ ), and Parauari Intrusive Suite (ca. $1.89 \mathrm{Ga}$ ). The Uatumã magmatic event comprises calc-alkaline basaltic andesite, andesite and rhyolite and volcaniclastic rocks of the Vila Riozinho Formation (ca. $2.0 \mathrm{Ga}$ ), unnamed rhyolites outcropping close to the Chapéu do Sol (ca. 2.0 and $1.88 \mathrm{Ga}$ ) and Novo Progresso (ca. 1.97-1.95 Ga) areas, and the Iriri Group (1.88 Ga). These volcanic units overlie most of the previous units.

A-type ignimbrites and rhyolites of the Moraes Almeida Formation (1.88 Ga; Lamarão et al., 2002), as well other less studied occurrences associated with large dikes and bodies of anorogenic granites of the Maloquinha Intrusive Suite (ca. $1.87 \mathrm{Ga}$ ) are common. Paleoproterozoic fluvial and marine units and several mafic intrusions also occur in the Tapajós Gold Province. The basement of the supracrustal sequences is not exposed in the Tapajós, but less evolved granitoids xenoliths (diorites, tonalites and granodiorites) and mafic rocks are common in all plutonic units, as well some ultramafic xenoliths. Geophysical and structural data, inherited zircon and $\mathrm{Sm}-\mathrm{Nd} \mathrm{T}_{\mathrm{DM}}$ ages indicate that this basement is composed of Archean and early Paleoproterozoic terranes (Lamarão et al., 2005). All these units are essentially unmetamorphosed, but zeolite to prehnite-pumpellyite facies have been identified in volcanic rocks in some regions and greenschist grade metamorphism is recognized in the Jacareacanga Group.

In the Tapajós Mineral Province, the Iriri Group was originated in several large nested ash-flow caldera complexes (Juliani et al., 2005). The pre-caldera units are composed of flows and dikes of basaltic andesite and andesite (Bom Jardim Formation) covered by rhyodacite, dacite, rhyolite and ignimbrites of the Salustiano Formation. Latite, trachyandesite, ash- and crystal tuffs, and acid to intermediate hyaloclastites are also present. The syn-caldera units consist of several large ignimbrite and ash-flow deposits with subordinated rhyolite flows of the Aruri Formation. The postcaldera units are represented mainly by rhyolites and ignimbrites, which encompass ring composite volcanoes and domes. The latter occur as vents along rings and within the calderas. Tuffs, epiclastic sandstone and lacustrine sediments compose the intra-caldera deposits. Intrusions of granophyric stocks, and rhyolitic and rhyodacitic porphyry dikes crosscut the volcanic sequence. These volcanic units are interfingered and are partially covered by Paleoproterozoic lacustrine, fluvial and marine sedimentary sequences.

A-type rhyolites of the Santa Rosa Formation form large NE-SW and NW-SE-striking dikes with domes and associated ignimbrite deposits (Juliani and Fernandes, 2010; Fernandes et al., 2011). Atype granites of the Maloquinha Intrusive suite are also common in this province (Santos et al., 2000). Large mafic intrusions and thin dikes with ages ranging from Paleoproterozoic to Neoproterozoic are also present.

The basement of the Central Amazonian Province is not well exposed but, at least in part, it is Archean in age (Santos et al., 2000).

\subsection{Epithermal gold mineralization}

More than twenty high-, intermediate- and low-sulfidation occurrences have been recognized in felsic and intermediatecomposition volcanic and volcaniclastic rocks. These occurrences are genetically associated with stocks and dikes of rhyodacitic to rhyolitic porphyries, which resulted in strong and extensive hydrothermal alteration in volcanic and volcaniclastic rocks of the Iriri Group. Among these, only one high-sulfidation mineralization was partially explored by drill holes and resources of 30 tons of gold with grade up to $4.5 \mathrm{ppm}$ Au were estimated.

The high-sulfidation gold mineralization (Figs. 5 and 6) occurs in hydrothermal breccia pipes affected by advanced argillic alteration with alunite-natroalunite veins and disseminated pyrophyllite, andalusite, diaspore, rutile, kaolinite-dickite, woodhouseite-svanbergite, hindaslite, pyrite, chalcopyrite, bornite, covellite, sphalerite, enargite-luzonite, tetrahedrite-tennantite, famatinite, tiemannite, kaolinite, pyrite, and very fine grains of native Au, Ag, and Cu (Juliani et al., 2005).

In the core of this zone, a massive to brecciated silica body, which flares upwards, is present. This silica body has alunite and subordinated pyrophyllite at shallow levels and sulfide-rich zones at deeper levels. The zone of advanced argillic alteration with alunite is enveloped by an advanced argillic alteration zone with rare alunite and without andalusite, indicating lower temperature in these external haloes (Fig. 6). Zones of argillic alteration represented by clay-rich rocks with veins of coarse-grained kaolinite occur in the outer parts of the previous zone. The advanced argillic alteration zone grades outward to a large propylitic halo in shallow parts, and to sericitic alteration at deeper levels, especially close to hydrothermally altered porphyry dikes. A hematite-rich silica cap with abundant vugs filled by diagenetic quartz occurs on the top of the hydrothermal breccia bodies. At least two pulses of hydrothermal fluids have been recognized, generating several alunite textural types (Juliani et al., 2005). The first pulse was more pervasive and cooler than the second one. The latter resulted in brecciation of the silica cap and generation of high-temperature 


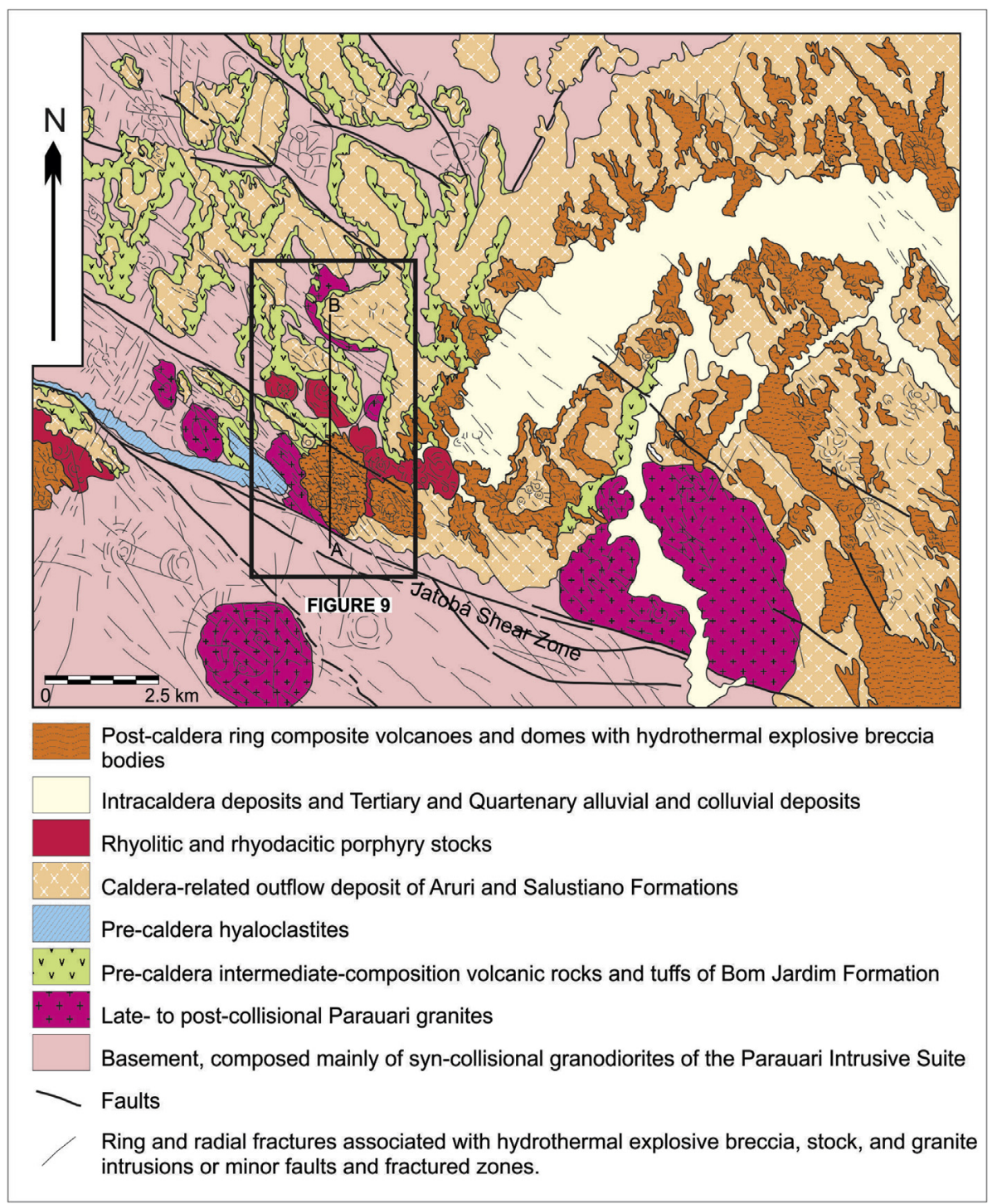

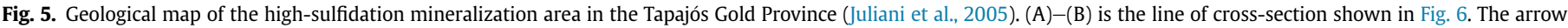
indicates the volcanic structure with high-sulfidation mineralization shown in Fig. 6, and the black star shows the location of the high-sulfidation gold deposit.

fine-grained alunite veins that crosscut alunitites, and coarsegrained alunite branching veins.

Undeformed alunite shows maximum age of $1869 \pm 2$ Ma and recrystallization in shear zones at $1805 \pm 2 \mathrm{Ma}$. Supergenic alunite has an ${ }^{39} \mathrm{Ar}-{ }^{40} \mathrm{Ar}$ age of $51.3 \mathrm{Ma}$, which indicates the period of epithermal mineralization erosion.

The $\delta^{34} S$ values of the alunite range from 14.0 to $36.9 \%$, and coexisting pyrite from -6.3 to $1.7 \%$. Temperatures estimated from the sulfur isotope composition of the alunite-pyrite pair and from oxygen isotope signature of $\mathrm{SO}_{4}-\mathrm{OH}$ alunite range from 130 to $420{ }^{\circ} \mathrm{C}$. The $\delta \mathrm{D}_{\mathrm{H}_{2} \mathrm{O}}$ and $\delta{ }^{18} \mathrm{O}_{\mathrm{H}_{2} \mathrm{O}}$ values $(-43$ to $-55 \%$ and $11.8-16.7 \%$, respectively) for alunite-forming hydrothermal fluids suggest a predominance of magmatic water, with a small meteoric contribution (Juliani et al., 2005). Calculated isotopic compositions for the fluids associated with the lower temperature alunite, pyrophyllite and kaolinite could be associated with two evolutionary trends. These trends could indicate a contribution of seawater, followed by an influx of low-latitude, highly evaporated waters, to the hydrothermal system. This suggests that during the late Paleoproterozoic, the Amazonian Craton was located in an arid, near equatorial environment (Juliani et al., 2011).
The low-sulfidation gold mineralization is located at the border of a caldera complex. The geological setting and the hydrothermal system evolution is similar to that of the high-sulfidation gold mineralization, but the silica cap is not present and the erosion and deformation related to shear zones are more intense. This epithermal mineralization shows an overprint of a porphyry style $\mathrm{Cu}-\mathrm{Mo}-(\mathrm{Au})$ mineralization associated with several porphyry dikes.

Tokashiki et al. (2015) also identified multiphase gold and base metal (chalcopyrite, galena, and sphalerite) veins hosted by 1.97 to 1.95 Ga rhyolites and volcaniclastic rocks. Two phases of rhyolites are responsible for domes cut by hydrothermal breccias, with talus breccias, volcanic agglomerates and tuffs surrounding the domes, and dikes. This mineralization is controlled by faults and is concentrated in and close to the rhyolitic domes, notably where dikes of rhyolites are present. The hydrothermal alteration, proximal in relation to the ore, is represented by mainly fissure controlled to pervasive sericitic alteration with sericite, sulfides, and, in many places, adularia, characterizing an epithermal lowsulfidation mineralization, associated with silicification and sulfidization. The external halo is represented by propylitic alteration, 

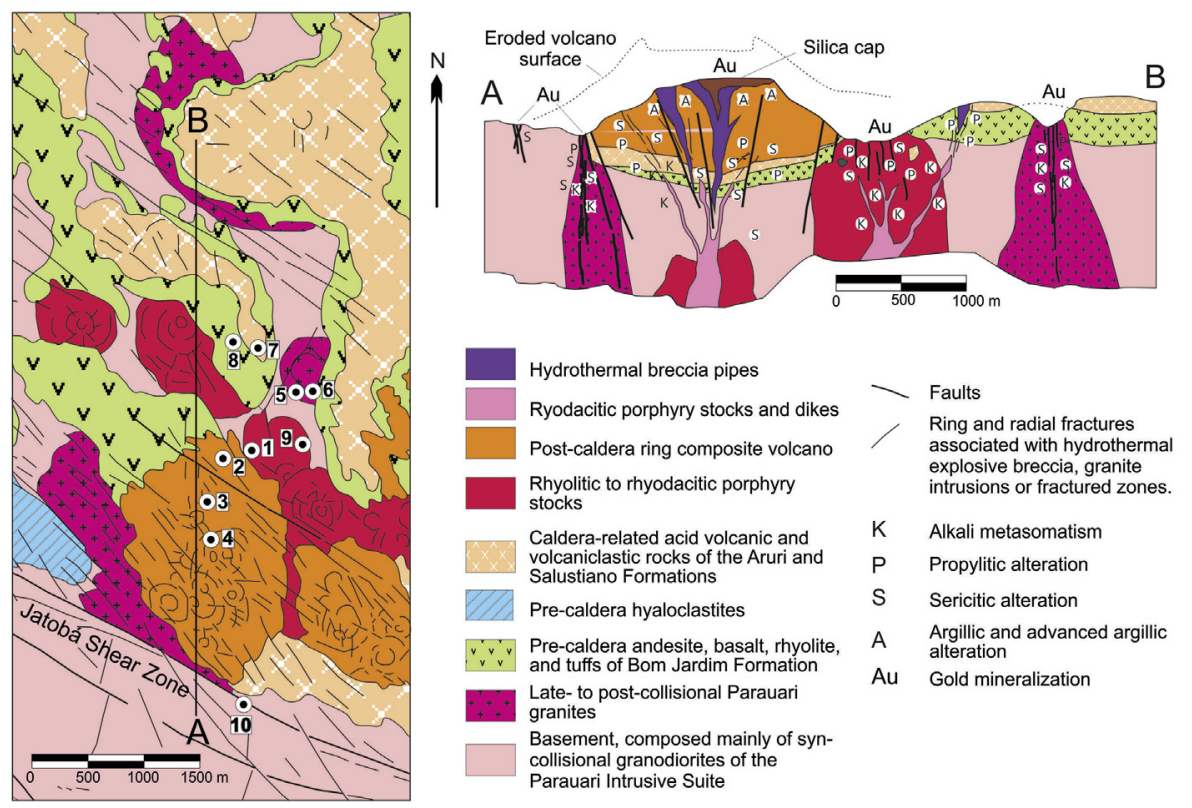

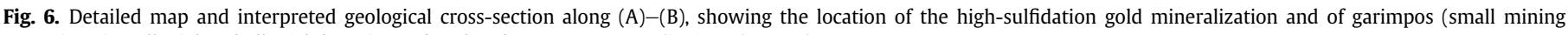
operations in colluvial and alluvial deposits undertaken by prospectors; Juliani et al., 2005).

and zones with intense argillic alteration are very common. Another characteristic of this mineralization is the presence of manganesiferous calcite and the base-metal sulfide-rich ores, typical of the intermediate-sulfidation epithermal mineralization (Sillitoe and Hedenquist, 2003; Corbett, 2008). Especially close to the dikes of rhyolites, $\mathrm{K}$-metasomatism is present and produces $\mathrm{K}$ feldspar + biotite \pm quartz \pm sulfides. This mineralization indicates that the epithermal systems, as well as the spanning of time of the Paleoproterozoic volcanism in the Amazonian Craton, are more spread out than previously considered.

Adularia-sericite $\mathrm{Cu}-\mathrm{Mo}-(\mathrm{Au})$, pyrophyllite-kaolinite-diaspore $\mathrm{Au}$, and several large sericitic alteration zones (sometimes with traces of $\mathrm{Au}, \mathrm{Bi}, \mathrm{Cd}, \mathrm{Sb}, \mathrm{Mo}, \mathrm{Pb}$ and $\mathrm{Zn}$ ) have also been identified along a west-east belt from the Tapajós to Xingu rivers along $\sim 650 \mathrm{~km}$.

\subsection{Porphyry-type gold mineralization}

Porphyry-related mineralization is represented mainly by the Palito $\mathrm{Au}-(\mathrm{Cu})$ deposit, and by the $\mathrm{Cu}-$ Mo porphyry style mineralization that overprinted the Chapéu do Sol low-sulfidation gold mineralization. Gold mineralization associated with the Batalha Granite is similar to those of Au-rich porphyry systems, but this granite was emplaced at a mesozonal crustal level (Juliani et al., 2002), precluding its classification as a porphyry-type mineralization, despite the similarity of the typology of the hydrothermal alteration.

The Palito granite composes a semi-eroded dome-like granophyric body (U-Pb TIMS zircon age of $1.883 \pm 11 \mathrm{Ga}$; Aquino et al., 2012) intruded the northern boundary of the shallow-emplaced intrusion of the Rio Novo porphyritic granite (U-Pb TIMS zircon age of $1.881 \pm 4 \mathrm{Ga}$; Lima et al., 2010). These granites are high-K calc-alkaline and are possibly correlated to the later Parauari granites of the Tapajós Mineral Province. They intruded the Fofoquinha granodiorite/quartz diorite (U-Pb zircon TIMS $1.946 \pm 57$ Ga; Lima, 2010). Porphyry stocks, sometimes brecciated, and several porphyry dikes, some of them affected by hydrothermal alteration crosscut the previous units. This association shows typical geochemical characteristics of porphyry generation in an active continental margin evolving to a late collisional stage (Echeverri-Misas, 2015).

The main wall-rock hydrothermal alteration recognized in the Palito and host rocks are potassic, propylitic, and sericitic (QSP), with restricted argillic alteration. The potassic alteration is very intense in the mineralized Palito Granite and decreases in intensity towards the host Fofoquinha and Rio Novo units. The alteration resulted in almost complete replacement of igneous feldspar by microcline and dark-colored igneous biotite and amphibole by green biotite. This potassic alteration was followed by propylitic alteration mainly in a fissure-controlled style, which evolved to Au and $\mathrm{Cu}$ mineralized sericitic alteration. An outer halo of propylitic alteration occurs around the Palito Granite.

The $\mathrm{Au}-(\mathrm{Cu})$ mineralization is represented by hundreds of NW-SE and E-W oriented sulfide-rich and quartz veins, metric massive chalcopyrite \pm covellite veins, and pyrite $\pm \mathrm{Cu}$-sulfide mineral lenses and veins. Massive sulfide veins are locally crosscut by hydrothermal brecciated sulfide veins and veinlets. All vein generations are commonly sheared. The ore grade and the size of mineralized veins decrease towards the host Rio Novo Granite. "Barren" samples of the Palito Granite without sericitic alteration have $0.25 \mathrm{ppm} \mathrm{Au} \mathrm{(up} \mathrm{to} 2.7 \mathrm{ppm}$ ).

Scanning electronic microscope studies indicate that the ore has chalcopyrite, pyrite, digenite, chalcocite, pyrrhotite, galena, sphalerite, covellite, gold, electrum, barite, argentumcuproauride, bismuth, bismuthinite, makovickyite, wittichenite, hedleyite, cuprobismuthinite, kupcikite, $\mathrm{Te}-\mathrm{Se}$-bismuth, $\mathrm{Ag}-\mathrm{Te}-\mathrm{Bi}$-tellurite, matildite, tetradimite, scheelite, ytrialite, monazite, thorite and pilsenite. Native gold is predominantly included in chalcopyrite. Later shear-related non-mineralized quartz veins have mainly pyrite, carbonates and fluorite.

Microthermometric studies indicate salinities up to $23.8 \mathrm{wt} . \%$ $\mathrm{NaCl}$ eq. and boiling evidences (Usero et al., 2011). $\delta \mathrm{D}_{\mathrm{H}_{2} \mathrm{O}}$ and $\delta^{18} \mathrm{O}_{\mathrm{H}_{2} \mathrm{O}}$ values of sericite vary between -38 and $-74 \%$, and $1.7-6.9 \%$, respectively. Stable isotope evidence indicates mixing involving magmatic-derived and meteoric hydrothermal fluids during the sericitic alteration and the ore deposition. This evolution is very similar to those observed in the high-sulfidation gold 
mineralization. $\delta^{34} \mathrm{~S}$ values $(1.2-3.6 \%$ ) of sulfides suggest a magmatic source for the sulfur (Echeverri-Misas, 2010).

The hydrothermal alteration associated with rhyolitic to rhyodacitic porphyry dikes that overprinted the low-sulfidation mineralization of Chapéu do Sol shares the same style and mineralogy with the Palito mineralization, as well the ores, but the content of molybdenum is higher, and is represented by molybdenite.

Many other occurrences of porphyry-style hydrothermal mineralization have been identified in the Tapajós in the last years (Juliani et al., 2013), indicating geological potential for occurrence of gold, and $\mathrm{Cu}-\mathrm{Mo} \pm \mathrm{Au}$ porphyry deposits in this region, associated with less evolved to high-K calc-alkaline granites.

\section{Alta Floresta Gold Province}

The Alta Floresta Gold Province (AFGP, also referred as Juruena-Teles Pires Gold Province) extends over $500 \mathrm{~km} \mathrm{NW-SE} \mathrm{in} \mathrm{the}$ southernmost portion of the AC (J.P. Souza et al., 2005). The province lies between the Ventuari-Tapajós (1.95-1.80 Ga) and Rio Negro-Juruena (1.80-1.55 Ga) geochronological provinces (Tassinari and Macambira, 1999), or between the Tapajós-Parima (2.03-1.88 Ga) and Rondônia-Juruena (1.82-1.54 Ga) tectonic provinces (Santos, 2003; Vasquez et al., 2008b). Regardless the adopted model, these provinces are interpreted as products of successive ocean-ocean orogenies with accretion of juvenile crust that evolved by differentiation generating intermediate to felsic magmas.

The AFGP is composed mainly of plutono-volcanic sequences generated in Paleo- to Mesoproterozoic volcanic arcs and basement units restricted to its central and northwest segments.

The basement is represented by two metamorphic complexes: (1) Bacareí-Mogno (2.24 Ga; Pimentel, 2001), composed of pyroxene-rich orthoamphibolite, ortho- and paragneiss, banded iron formations, quartzite, metagabro, and metanorites; and (2) Cuiú-Cuiú (1992 \pm 7 Ma; J.P. Souza et al., 2005; V.S. Souza et al., 2005), represented by tonalitic to granitic gneisses, migmatites, schists, banded iron formations, metaultramafic and metamafic rocks (Dardenne and Schobbenhaus, 2001; Paes de Barros, 2007).

In the eastern sector of the province, the basement is crosscut by several oxidized, calc-alkaline, medium to high-K, meta- to peraluminous granites, such as Pé Quente, Novo Mundo, and Aragão granites, and the Flor da Mata suite, besides volcanic sequences (Assis et al., 2014). The plutonic-volcanic units have U-Pb crystallization ages varying from $1.97 \mathrm{Ga}$ to $1.93 \mathrm{Ga}$. These suites are also cut by the $1.90 \mathrm{Ga}$ to $1.87 \mathrm{Ga}$ Guarantã, Nhandu, and Matupá I-type granites, and by ca. $1.78-1.75$ Ga post-collisional and A-type granites (e.g. Paranaíta and Peixoto granites, Colíder and Teles Pires suites). Except for the Flor da Mata suite, all other granites host vein-type to disseminated gold mineralization. All these units are overlain by ca. $1.37 \mathrm{Ga}$ (Assis et al., 2014) clastic sedimentary rocks attributed to the Dardanelos Formation (Beneficente Group).

Crystallization ages (1.97 $\mathrm{Ga}$ to $1.75 \mathrm{Ga}$ ), Sm-Nd $\mathrm{T}_{\mathrm{DM}}$ ages (2.76 Ga to $2.15 \mathrm{Ga}$ ), and $\varepsilon_{\mathrm{Nd}(\mathrm{t})}$ values from -7.62 to 3.09 for the plutono-volcanic units, suggest Archean to Paleoproterozoic magma sources within a juvenile arc with a small contribution of continental crust (Santos et al., 1997, 2000; Moura, 1998; Pimentel, 2001; J.P. Souza et al., 2005; Paes de Barros, 2007; Silva and Abram, 2008; Assis et al., 2014; Assis, 2015).

\subsection{Gold metallogeny of the Alta Floresta Province}

The majority of the gold deposits and occurrences recognized in the AFGP are concentrated along a NW-SE-striking belt that extends over $150 \mathrm{~km}$. Based on mode of occurrence, ore mineral association, and geochemical signature, these deposits are classified as: (1) disseminated; (2) structurally-controlled vein-type Au deposits; and (3) structurally-controlled vein-type $\mathrm{Au}+$ base metals. Main host rocks include tonalite to syeno/monzogranite intrusions (1.97 Ga, $1.90 \mathrm{Ga}$ and $1.87 \mathrm{Ga}$ ), quartz-feldspar porphyries (1.78-1.75 Ga) and, subordinate basement rocks (2.0 Ga to $1.98 \mathrm{Ga}$ ). In some deposits, aplite and mafic intrusions of unknown ages often contain gold mineralization.

\subsubsection{Disseminated Au deposits}

The Luizão (Paes de Barros, 2007), Serrinha (Moura, 1998), Juruena (Serrato, 2014), X1 (Rodrigues, 2012), and Pé Quente (Assis, 2011) deposits are the main examples of disseminated gold deposits. The Novo Mundo and Matupá granites host the Luizão and Serrinha deposits, whereas the Guarantã granite hosts the X1 and Pé Quente deposits. The Juruena deposit is hosted by biotite monzogranite, porphyritic biotite monzogranite and microgranite, possibly belonging to the Paranaíta suite. These granites are I-type, oxidized (magnetite-bearing), sub-alkaline to calc-alkaline, metaluminous to slightly peraluminous, medium to high potassium with compositions varying from syenogranite/monzogranite (e.g. Novo Mundo and Juruena granites) to granodiorite/tonalite (Guarantã granite)

Single zircon $\mathrm{Pb}$-evaporation yielded crystallization ages from $1970 \pm 3$ to $1964 \pm 1 \mathrm{Ma}$ for the Novo Mundo granite (Sm-Nd $\mathrm{T}_{\mathrm{DM}}=2.76 \mathrm{Ga}$ and $\left.\varepsilon_{\mathrm{Nd}(\mathrm{t})}=-7.32\right)$, and $1872 \pm 12$ Ma for the Matupá granite $\left(\mathrm{Sm}-\mathrm{Nd} \mathrm{T}_{\mathrm{DM}}=2.47\right.$ to $2.43 \mathrm{Ga}$ and $\varepsilon_{\mathrm{Nd}(\mathrm{t})}=-4.3$ to -2.7 ; Moura, 1998; Paes de Barros, 2007). Moreover, SHRIMP U-Pb zircon crystallization ages varying from $1904 \pm 4.6$ to $1901 \pm 6.8 \mathrm{Ma}$ were obtained for the Guarantã granite $\left(\mathrm{Sm}-\mathrm{Nd} \mathrm{T}_{\mathrm{DM}}=2.5\right.$ to $2.4 \mathrm{Ga}$ and $\varepsilon_{\mathrm{Nd}(\mathrm{t})}=-5.13$ to -3.21$)$ and ages of $1790 \pm 6.4 \mathrm{Ma}$ for the Juruena granite (Serrato, 2014; Assis, 2015).

The ore bodies of these deposits occur within muscovite (phengite)/sericite + quartz + chlorite alteration zones that are enveloped by pervasive potassic (orthoclase + microcline \pm hematite), and then by later and more regional propylitic alteration. These alteration types are also recognized in the Pé Quente deposit, but gold mineralized zones are related to earlier pervasive sodic alteration and to later quartz + albite-rich veinlets.

The ore zones of these disseminated gold deposits contain abundant pyrite with variable concentrations of chalcopyrite and hematite, with minor barite, galena, sphalerite, monazite, thorite, molybdenite, pyrrhotite, cubanite, $\mathrm{Bi}-\mathrm{Te}$-bearing phases and $\mathrm{Au}-\mathrm{Ag}$ tellurides. Gold $(\mathrm{Ag}=4-46 \%)$ usually occurs as small inclusions within pyrite, at its edges or as fracture infilling.

Fluid inclusion assemblages reveal the common presence of: (1) two-phase aqueous inclusions with variable salinity (2.1-26.1 wt.\% eq. $\mathrm{NaCl}$ ) and homogenization temperatures $\left(126.5{ }^{\circ} \mathrm{C}-268.4^{\circ} \mathrm{C}\right)$; (2) $\mathrm{H}_{2} \mathrm{O}-\mathrm{CO}_{2}$ inclusions of low salinity $(6.1-8.9 \mathrm{wt} . \%$ eq. $\mathrm{NaCl})$ and higher temperatures $\left(251.6^{\circ}-334.6^{\circ} \mathrm{C}\right)$; and more subordinately (3) high salinity (33.6-37 wt\% $\mathrm{NaCl}$ eq.) aqueous fluids represented by halite-bearing fluid inclusions (Fig. 7A). These data suggest a combination of heterogeneous entrapment by immiscibility and fluid mixing during the evolution of the hydrothermal systems. Additionally, these results indicate P-T conditions of $0.9-3.4 \mathrm{kbar}$ (3.3-12.6 km) and $110^{\circ}$ to $365^{\circ} \mathrm{C}$.

The $\delta^{18} \mathrm{O}_{\text {silicate }}$ and $\delta \mathrm{D}_{\text {silicate }}$ data vary from $4.3 \%$ to $13.4 \%$ and from $-65 \%$ to $-34 \%$, respectively, whereas $\delta^{34} S_{\text {sulfide }}$ are between $-5.6 \%$ and $1.8 \%$. Moreover, the calculated $\delta^{18} \mathrm{O}_{\mathrm{H}_{2} \mathrm{O}}$ and $\delta \mathrm{D}_{\mathrm{H}_{2} \mathrm{O}}$ values $\left(\delta^{18} \mathrm{O}_{\mathrm{H}_{2} \mathrm{O}}=2.7 \% 0-8.4 \%\right.$; $\delta \mathrm{D}_{\mathrm{H}_{2} \mathrm{O}}=-35 \%$ to $-69 \%$; Fig. 7B; Assis, 2015) for the fluids in equilibrium with quartz and muscovite in the ore assemblage point to a predominant contribution of magmatic fluids for the formation of the disseminated $\mathrm{Au}$ deposits.

The pyrite and molybdenite $\mathrm{Re}-\mathrm{Os}$ weighted average model 


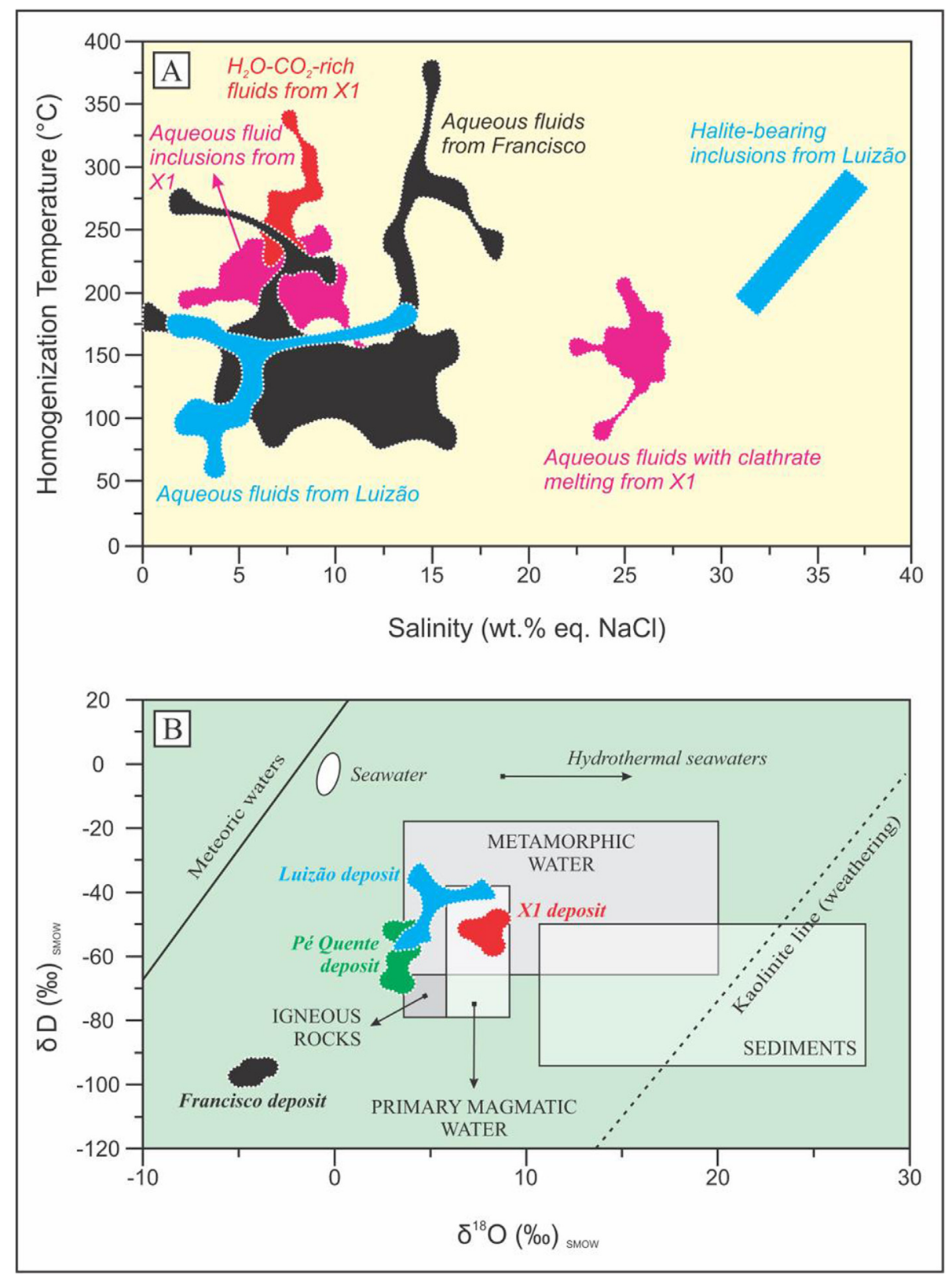

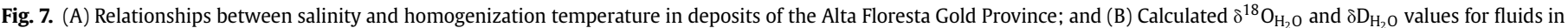
equilibrium with hydrothermal minerals of the gold deposits from AFGP (Assis, 2015).

ages obtained for the disseminated $\mathrm{Au} \pm \mathrm{Cu}$ deposits are $1787 \pm 6.2 \mathrm{Ma}$ (Luizão), $1787 \pm 5.5 \mathrm{Ma}$ (Pé Quente), and $1786 \pm 5 \mathrm{Ma}$ (X1; Fig. 8; Assis, 2015). Considering the isotopic uniformity among these three deposits, which might reflect a single and similar rhenium source, a very well defined ${ }^{187} \mathrm{Re}-{ }^{187}$ Os isochron age $(1786 \pm 1 \mathrm{Ma})$ and a weighted average model age of $1787 \pm 3.2 \mathrm{Ma}$ were obtained for them.

\subsubsection{Vein-type Au deposits}

The Paraíba (Paes de Barros, 1994; Trevisan, 2015), Edú (Paes de Barros, 2007) and Peteca (Teixeira, 2015) deposits are the main vein-type Au deposits.

The Paraíba deposit is hosted by biotite tonalite and biotite gneiss crosscut by mafic dikes, whereas biotite granodiorite and biotite syenogranite are the main host rocks of the Peteca deposit. The Edú deposit is hosted by the Santa Helena granite, individualized into two facies that comprise monzogranite to granodiorite (Old Santa Helena granite; U-Pb LA-ICP-MS zircon; $1986 \pm 6 \mathrm{Ma}$ ), and fine- to medium-grained monzogranite (Young Santa Helena Granite; $1967 \pm 3 \mathrm{Ma}$; single-zircon Pb evaporation).

The gold mineralization is generally associated with quartz veins emplaced in sericite-quartz-biotite-carbonate mylonitic zones within $\mathrm{N}-\mathrm{S}-$, NE- and $\mathrm{E}-\mathrm{W}$-striking shear zones of subvertical dip. These mylonitic zones are enveloped by early potassic (with K-feldspar) alteration, and by later, and distal, propylitic alteration.

The ore association in the veins consists predominantly of pyrite with significant amounts of chalcopyrite, and minor galena, scheelite, sphalerite, hematite, magnetite, $\mathrm{Bi}-\mathrm{Te}-\mathrm{Ag}$-bearing phases, and gold (16-30\% Ag; Assis et al., 2014).

Fluid inclusion assemblages reveal the common presence of: (1) two-phase $\mathrm{H}_{2} \mathrm{O}-\mathrm{NaCl}-\mathrm{CaCl}_{2}$-rich fluids with low to moderate 


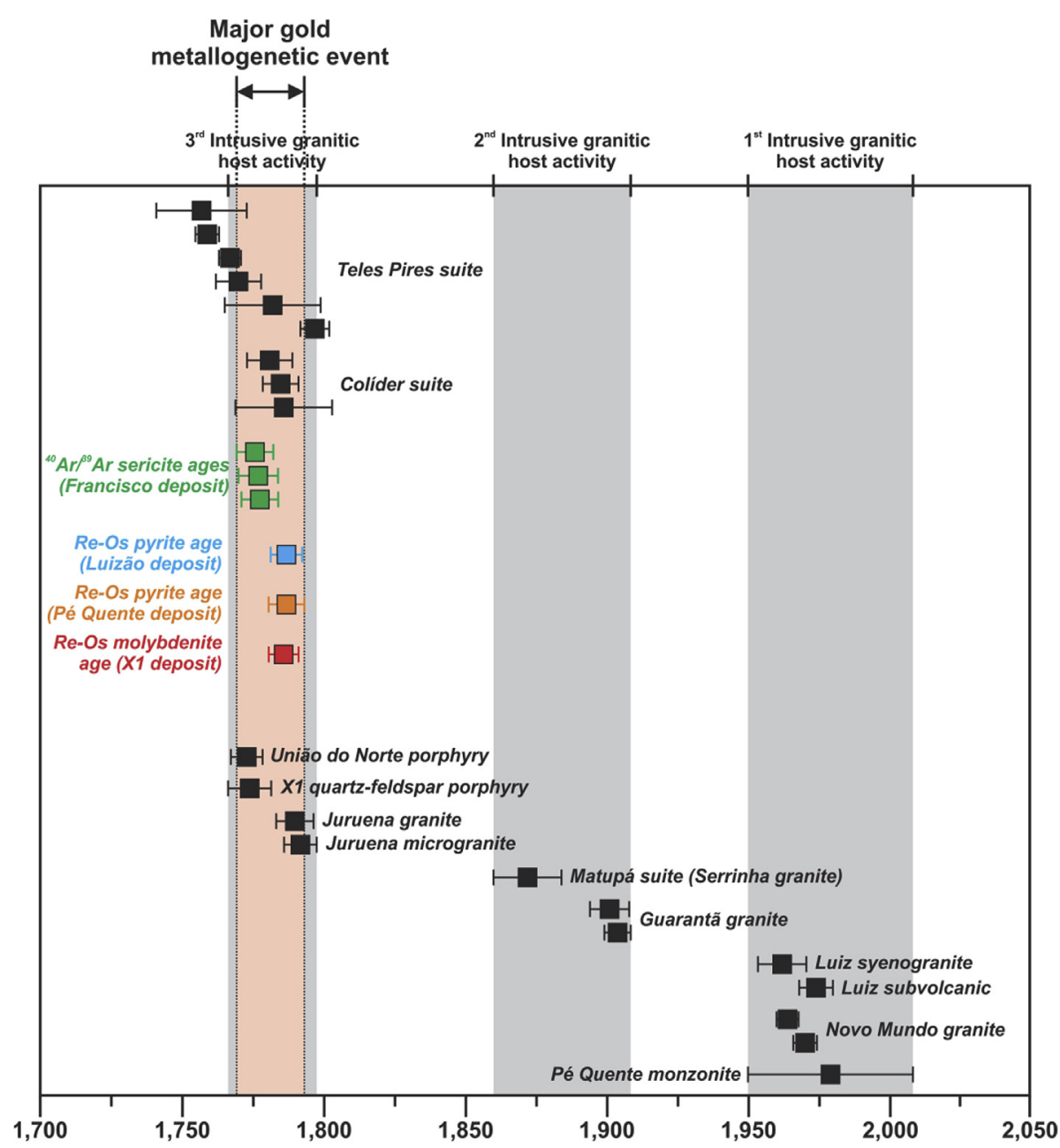

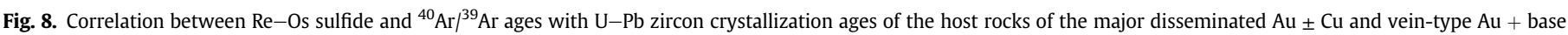
metals deposits in the Alta Floresta Gold Province (Assis, 2015).

salinity ( $2-13$ wt.\% eq. $\mathrm{NaCl})$ and temperature $\left(79^{\circ}<\mathrm{T}<234^{\circ} \mathrm{C}\right)$; (2) $\mathrm{H}_{2} \mathrm{O}-\mathrm{CO}_{2}$ inclusions with heterogeneity of degree of fill, low to moderate salinity (1.6-14.5 wt.\% eq. $\mathrm{NaCl}$ ) and higher homogenization temperatures $\left(159-360{ }^{\circ} \mathrm{C}\right.$ ); and (3) $\mathrm{H}_{2} \mathrm{O}-\mathrm{NaCl}-\mathrm{CaCl}_{2}$ halite-bearing fluid inclusions of higher temperature $\left(286.5^{\circ}-316^{\circ} \mathrm{C}\right)$ and salinity $(37-43.5$ wt.\% eq. $\mathrm{NaCl})$. The calculated pressure and temperature conditions vary, respectively, from 1.0 to $3.6 \mathrm{kbar}$ and from $263^{\circ}$ to $368^{\circ} \mathrm{C}$ (Assis et al., 2014).

\subsubsection{Vein-type $A u+$ base metal deposits}

The Francisco, Bigode, and Luiz deposits (Assis, 2008, 2011; Trevisan, 2015) are the main examples of vein-type $\mathrm{Au}+$ base metal deposits located in the eastern sector of the AFGP, in the vicinities of the União do Norte district.

The Francisco deposit is hosted by a volcaniclastic unit of uncertain age, close to the contact with the União do Norte porphyry, dated at $1774 \pm 7.5 \mathrm{Ma}$ (LA-ICP-MS U-Pb zircon). The latter corresponds to a post-collisional $A_{2}$-type sub-volcanic intrusion that ranges in composition from monzogranite to alkali-feldspar granite (Assis, 2011; Miguel-Jr, 2011). The União do Norte porphyry crosscut an I-type magnetite-bearing hornblende-biotite granodiorite $(1853 \pm 23 \mathrm{Ma}$; U-Pb LA-ICP-MS zircon) that hosts the Bigode deposit (Assis, 2011; Miguel-Jr, 2011). The Luiz deposit is hosted by a biotite granodiorite that is intruded by a feldspar porphyry of granodioritic composition (1.974 $\pm 5.9 \mathrm{Ma}$; U-Pb SHRIMP zircon;
Trevisan, 2015).

Potassic (orthoclase \pm hematite) and propylitic (chlorite + epidote + magnetite \pm actinolite \pm calcite) hydrothermal alteration zones are distal, whereas sericite + quartz \pm chlorite alteration envelops the ore zones. These are confined to breccias and quartz veins that commonly show small geodes and open space-filling textures, such as crustiform, zonal, colloform, cockade, vuggy, and comb, suggesting emplacement at relatively shallow levels (Assis, 2011; Trevisan, 2015). The major ore association in these deposits comprises pyrite, sphalerite, and galena, with subordinate chalcopyrite, digenite, bornite, pyrrhotite, hematite, magnetite, greenockite, rutile, apatite, monazite, and $\mathrm{Bi}-\mathrm{Te}$-rich phases. Gold $(\mathrm{Ag}=2-41 \%)$ occurs as inclusions in pyrite and shows strong spatial association with galena, often as exsolutions.

Fluid inclusion assemblages in quartz from the quartz infill stage of the Francisco deposit are dominated by $\mathrm{CO}_{2}$-free primary aqueous fluids with heterogeneity in the degree of fill $(5 \%-70 \%)$, low to high salinity (6.9-24.2 wt\% $\mathrm{NaCl}$ eq.), and low to moderate homogenization temperatures $\left(85.3^{\circ}<\mathrm{T}<373.2{ }^{\circ} \mathrm{C}\right.$; Fig. $\left.7 \mathrm{~A}\right)$. Although in minor amounts, colorless $\left(\mathrm{H}_{2} \mathrm{O}\right.$-rich liquid phase) to dark-color $\left(\mathrm{H}_{2} \mathrm{O}\right.$-rich vapor phase) monophase inclusions are also related to ore zones of these deposits (Assis, 2015; Trevisan, 2015). These data suggest P-T conditions of approximately 0.74 kbar $(\sim 2.7 \mathrm{~km})$ and $85{ }^{\circ} \mathrm{C}-373^{\circ} \mathrm{C}$.

Although microthermometric data are not available for Luiz 
deposit, chlorite and muscovite mineral chemistry yields temperatures from $233{ }^{\circ} \mathrm{C}$ to $300{ }^{\circ} \mathrm{C}$ (Trevisan, 2015). The isotopic signature, only available for the Francisco deposit, shows $\delta^{18} \mathrm{O}_{\text {silicate }}$ and

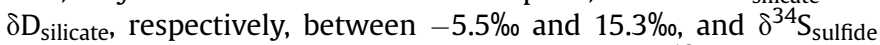
ranging from $-2.6 \%$ to $1.3 \%$. The calculated $\delta^{18} \mathrm{O}_{\mathrm{H}_{2} \mathrm{O}}(-4.8 \%$ o to $-3.5 \%$ ) and $\delta \mathrm{D}_{\mathrm{H}_{2} \mathrm{O}}(97.3 \%$ to $-94.4 \%$; Fig. $7 \mathrm{~B})$ values suggest external fluids of meteoric origin that may have interacted with magmatic fluids.

Additionally, sericite ${ }^{40} \mathrm{Ar} /{ }^{39} \mathrm{Ar}$ plateau ages from the sericitic alteration halo of the Francisco deposit (Assis, 2015) yielded ages between $1779 \pm 6.6 \mathrm{Ma}$ and $1777 \pm 6.4 \mathrm{Ma}$ (Fig. 8 ), which are very similar to those constrained for the disseminated $\mathrm{Au} \pm \mathrm{Cu}$ deposits.

\section{Eastern Amazonian Craton (Transamazonas Province)}

The eastern portion of the AC corresponds to the Transamazonas Province (Santos, 2003), which broadly represents a north-southtrending orogenic belt, with internal structures oriented predominantly to NW-SE and E-W. The belt consolidated during the Transamazonian cycle of orogenies $(2.26-1.95 \mathrm{Ga})$ and its framework and evolution is heterogeneous and characterized by several tectonic domains (Fig. 2): (1) Lourenço, (2) Amapá, (3) Carecuru, (4) Bacajá, and (5) Santana do Araguaia (Santos, 2003; Rosa-Costa et al., 2006, 2014; Macambira et al., 2007; Fig. 9).

The Lourenço Domain is a Rhyacian terrane composed of several orogenic granitoid suites of variable composition, from quartz diorite to granite, with ages between 2.19 and $2.06 \mathrm{Ga}$. The oldest suites are interpreted as having formed in a continental arc setting (Nogueira et al., 2000; Sousa and Costa Neto, 2014). Gneisses, amphibolite and discontinuous strips of metavolcano-sedimentary rocks are subordinate. Younger rocks include late- to post-orogenic granitoids and charnockite of 2.05 to 1.99 Ga (Faraco et al., 2009; Sousa and Costa Neto, 2014).

The Amapá Block comprises an Archean crust that has been reworked during the Rhyacian period. Its basement is composed of 2.87 to $2.60 \mathrm{Ga}$ metagranite-gneiss-migmatite-granulite associations with remnants of older, Paleoarchean gneissic crust (3.49-3.32 Ga), high-grade metasedimentary sequences younger than $3.10 \mathrm{Ga}$, and charnockites $(2.66-2.63 \mathrm{Ga})$. This basement records granulite facies metamorphism at 2.10 to $2.08 \mathrm{Ga}$ and has been intruded by pre-orogenic 2.22 Ga layered mafic-ultramafic and by several generations of orogenic granitoids (2.19 and $1.99 \mathrm{Ga}$ ). Anorogenic granitic magmatism took place between 1.84 and $1.75 \mathrm{Ga}$. Greenschist to granulite facies supracrustal rocks occur as disrupted and elongated NW-SE trending sequences, composed of mafic-ultramafic volcanic rocks and chemical and clastic sedimentary rocks (Rosa-Costa et al., 2006, 2014; Barbosa et al., 2013).

The Carecuru Domain encompasses gneisses, 2.19 to $2.14 \mathrm{Ga}$ calc-alkaline granitoids, narrow and discontinuous belts of metavolcano-sedimentary rocks, and remnants of Archean granulite gneiss formed in a magmatic arc setting. Younger units comprise syn- to post-collisional granitoids (2.10-2.03 Ga; RosaCosta et al., 2006 and references therein).

The basement rocks of the Bacajá Domain are composed of Archean (3.0-2.5 Ga) granulite, charnockite, gneiss, granitoid and 2.44 to 2.31 Ga greenstone belts, reworked during the Rhyacian period. Orogenic magmatic arc-related granitoids and charnockites, related to the collision of magmatic arcs against an Archean block (Vasquez et al., 2008a), were produced during syn- and postcollision stages, at 2.11 to $2.09 \mathrm{Ga}$ and 2.08 to $2.06 \mathrm{Ga}$, respectively.

The Santana do Araguaia Domain (Macambira et al., 2007) represents a granitoid-greenstone association composed of gneisses and metagranitoids of 3.06 to $2.42 \mathrm{Ga}$, and greenstones older than $2.83 \mathrm{Ga}$ (Vasquez et al., 2008a; Corrêa and Macambira, 2014). These associations were largely reworked during the Paleoproterozoic Era, by the intrusion of orogenic, pre-collision (?) granitoids of $2.19 \mathrm{Ga}$, but there is no clear evidence of Paleoproterozoic metamorphism (Corrêa and Macambira, 2014). Postorogenic granodiorite and enderbite intruded at 1.99 Ga (Corrêa and Macambira, 2014), and anorogenic magmatism is represented by 1.88 Ga A-type granites (Barros et al., 2011) and undated syenites.

\subsection{Characteristics of some major ore deposits and occurrences}

The Lourenço Domain contains gold deposits (1.1 Moz) hosted within shear zones that cut across 2.15 Ga biotite tonalite (Lourenço Tonalite; Nogueira et al., 2000; Klein et al., 2014; Sousa and Costa Neto, 2014). Mineralization took place at ca. $2.00 \mathrm{Ga}$, and the associated hydrothermal alteration produced silicification, saussuritization, chloritization, and sulfidation of the host tonalite (Nogueira et al., 2000). Bettencourt and Nogueira (2008) ascribed the deposit to the class of orogenic gold deposits, although Klein et al. (2014) argue that the classification is uncertain.

Small artisanal mining of $\mathrm{Nb}-\mathrm{Ta}$ (columbite-tantalite) is a common feature in areas where the Lourenço Tonalite crop out. These are associated with pegmatite and the causative pluton is unknown to date, but in other domains of the province, they are

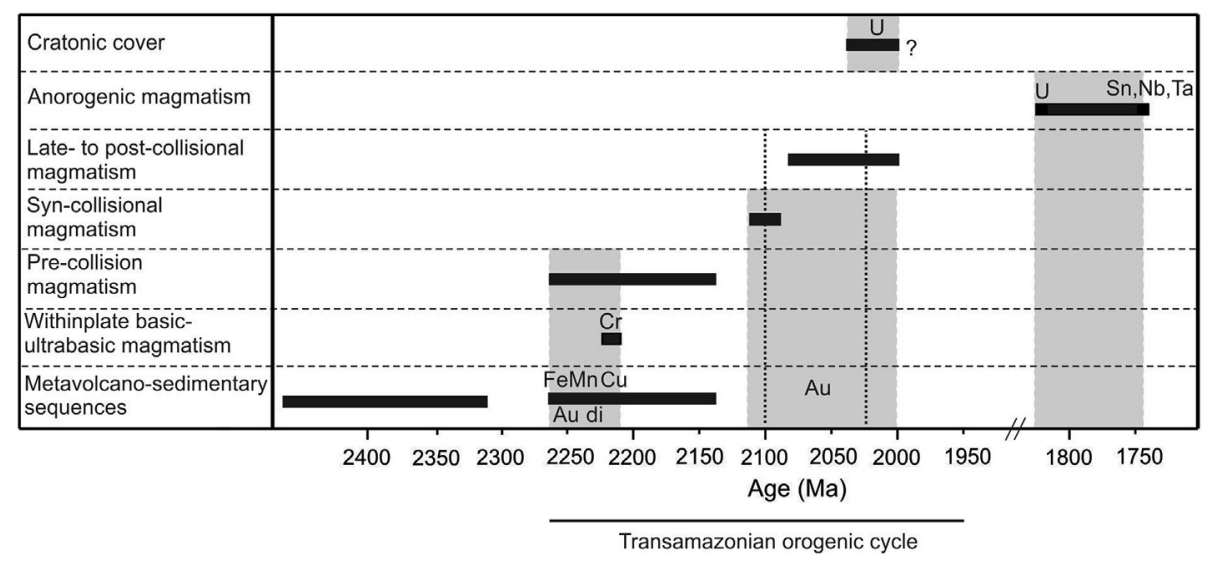

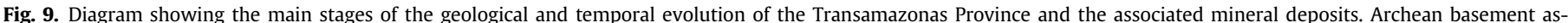

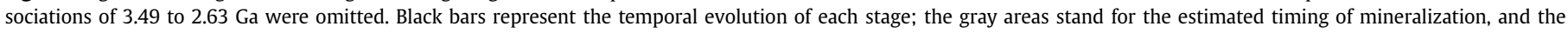
vertical dotted lines limit the timing of Rhyacian metamorphism associated with the Transamazonian orogenic cycle (bottom line; modified from Klein et al., 2014). 
associated with younger anorogenic granites.

The gold deposits of the Amapá Block are hosted in the metavolcano-sedimentary Vila Nova Group ( $>2.26 \mathrm{Ga}$ ). The goldsulfide ore in the main gold deposit (e.g. Amapari/Tucano) is hosted in a $\mathrm{N}-\mathrm{S}$ trending shear zone that affected amphibolite facies pelitic schists, BIF and carbonate rocks. Mineralization was produced by low-salinity aqueous-carbonic fluids at $270^{\circ} \mathrm{C}$ to $>420^{\circ} \mathrm{C}$, which has been interpreted as metamorphic in origin. This and other deposits of the same domain have been ascribed to the class of orogenic gold deposits (Melo et al., 2003; Nunes et al., 2007; Klein et al., 2014). Ore deposition is estimated to have occurred at ca. $2.11 \mathrm{Ga}$ (Pb isotopes in sulfides; Galarza et al., 2006). In addition, part of the mineralization occurs in skarns produced by the intrusion of the $1.99 \mathrm{Ga}$ Amapari Granite. It is likely that this intrusion caused at least local remobilization. In fact, Melo et al. (2003) identified high-salinity aqueous fluid inclusions that have been related to the Amapari Granite, although the authors have interpreted this fluid as unrelated to the main gold mineralization.

Greisen and pegmatite $\mathrm{Sn}-\mathrm{Nb}-\mathrm{Ta}$ deposits have been exploited by artisanal miners since 1940 . Most deposits are hosted in schists, quartzite and phyllite of the Vila Nova Group. These deposits are inferred to be related to late-orogenic to anorogenic (partly A-type) granites of 1.84 to 1.75 Ga (Barbosa et al., 2013; Klein et al., 2014).

Gold deposits of the Carecuru Domain are associated with Rhyacian supracrustal-granitoid associations formed in a continental arc setting. The host rocks are quartzite, metapelite, BIF, and subordinate calc-alkaline monzogranite and tonalite of 2.18-2.14 Ga (Klein and Rosa-Costa, 2003; Rosa-Costa et al., 2006). The gold-quartz veins are post metamorphic peak, hosted in shear zones, reverse-oblique faults and in the metamorphic foliation and were ascribed to the class of orogenic gold deposits. The timing of mineralization was estimated at ca. $2.03 \mathrm{Ga}$, based on the intrusion of syn-tectonic muscovite- and/or garnet-bearing granites (Klein and Rosa-Costa, 2003; Klein et al., 2009).

Fluid inclusion and isotopic studies indicate low-salinity metamorphic and magmatic fluid sources that deposited gold at 290-355 ${ }^{\circ} \mathrm{C}$ in the majority of deposits (Klein et al., 2009). In addition, deep-seated $\mathrm{CO}_{2}$ sources for a peculiar type of $\mathrm{CO}_{2}$-only fluid that formed deposits at $350-475^{\circ} \mathrm{C}$ have been reported (Klein and Fuzikawa, 2010). For the lower temperature group, potential magmatic fluid sources are the syn-tectonic granitoids of $2.03 \mathrm{Ga}$ (Klein et al., 2009), whereas for the higher temperature type, Klein and Fuzikawa (2010) suggested the widespread charnockite magmatism of $2.07 \mathrm{Ga}$, and the coeval granulite metamorphism to be the sources for $\mathrm{CO}_{2}$.

Secondary tin deposits occur in small rivers that transect an anorogenic, A-type granite of 1.75 Ga (Waiãpi Granite) and are probably related to this magmatism.

Ore deposits of the Bacajá domain still wait for characterization studies. Manelão is possibly an intrusion-related gold deposit. There, gold mineralization occurs in veins hosted in a NW-SEtrending shear zone that cut across amphibolite and mafic schists of the São Manoel sequence, close to the contact with the Felicio Turvo Granite of $2069 \pm 6$ Ma (Souza et al., 2003; Souza and Kotschoubey, 2005). Gold-quartz veining is associated with phyllic (quartz-sericite-albite with tourmaline-pyrite), and propylitic (chlorite-zoisite-clinozoisite-quartz-albite with pyrite, chalcopyrite, pyrrhotite and ilmenite) alteration haloes.

Two gold showings have been recognized in the Santana do Araguaia Domain, in addition to geochemical evidence of $\mathrm{Sn}, \mathrm{Pb}, \mathrm{Ag}$, and $\mathrm{Cu}$ mineralization (Stropper et al., 2011; Klein et al., 2014). Mandi is possibly an intrusion-related type and consists of a NE-SW-trending quartz lode system, hosted in two-mica leucogranites (Macambira et al., 2006) attributed to the Neoarchean Santana do Araguaia Complex (Vasquez et al., 2008b). The veins are enveloped by proximal silicification, sericitization and sulfidation haloes. Sericite also occurs as distal alteration (Macambira et al., 2006).

Stropper et al. (2011) described propylitic and potassic alteration zones associated with sulfides in I-type granites of the Vila Rica Intrusive Suite $(1990 \pm 12 \mathrm{Ma})$, and suggested potential for porphyry-type base metal mineralization.

\section{Pitinga Tin Province}

The Pitinga Province (Fig. 10) is the largest Sn producer in Brazil. It contains two main tin-bearing granites, the Madeira and Água Boa A-type granites, which are part of the ca.1820 Ma Madeira Suite (Fig. 11). The Madeira Sn-Nb-Ta-F world-class deposit, associated with the albite-enriched granite (AEG) facies of the Madeira granite (Fig. 11) has been exploited since 1989. A number of small greisens associated with the Água Boa granite have been intermittently exploited. The alluvial ore deposits, discovered in 1979 (Veiga et al., 1979), are almost exhausted.

The Pitinga Province is located in the southern portion of the Guyana Shield (Almeida et al., 1981; Rosa et al., 2014), in the Tapajós-Parima Tectonic Province (Santos et al., 2000), in the Uatumã-Anauá Domain (CPRM, 2006; Fig. 2). Its older units (Fig. 10) are grouped in the Guianense Complex (Issler et al., 1974). The Água Branca Suite (Araújo Neto and Moreira, 1976; Almeida et al., 1997) is composed of subduction-related calc-alkaline metaluminous granitoids (ca. $1950 \mathrm{Ma}$ ). Mandetta et al. (1974) recognized the "brachisyncline" of the Pitinga River, which is outlined by the Quarenta Ilhas Formation. According to Ferron et al. (2002), there is an even larger structure (dotted line in Fig. 10) approximately parallel to the brachisyncline.

The volcanic rocks of the Iricoumé Group (Veiga et al., 1979) have ${ }^{207} \mathrm{~Pb} /{ }^{206} \mathrm{~Pb}$ zircon ages between $1881 \pm 2$ and $1890 \pm 2 \mathrm{Ma}$ (Ferron et al., 2006). They comprise mostly effusive and hypabyssal rhyolites, highly welded ignimbrites, ignimbritic tuffs, and surge deposits, formed in a subaerial environment with cyclic effusive and explosive activities (Pierosan et al., 2011a, 2011b; Simões et al., 2014).

The granitic bodies $\left(1875 \pm 3 \mathrm{Ma}\right.$ and $1888 \pm 3 \mathrm{Ma} ;{ }^{207} \mathrm{~Pb} /{ }^{206} \mathrm{~Pb}$ zircon ages; Ferron et al., 2006, 2010) of the Mapuera Intrusive Suite (Araujo Neto and Moreira, 1976) intrude the Iricoumé Group. The volcanic and granitic rocks exhibit similar geochemical characteristics pointing to their comagmatic character. These rocks range from metaluminous to slightly peraluminous and exhibit affinities with silica-saturated alkaline series and A-type magmas. They contain between 6.6 and $10.4 \% \mathrm{Na}_{2} \mathrm{O}+\mathrm{K}_{2} \mathrm{O}$ and show $\mathrm{FeO}^{\mathrm{t}}$ / $\left(\mathrm{FeO}^{\mathrm{t}}+\mathrm{MgO}\right)$ values varying from 0.76 to 0.99 and $\mathrm{Ga} / \mathrm{Al}$ ratios of 1.5-4.9. The units plot in the intraplate or post-collisional fields in the $\mathrm{Y}+\mathrm{Nb} v s$. $\mathrm{Rb}$ diagram. The $\mathrm{Nb} / \mathrm{Y}$ ratios indicate that these rocks are comparable to $A_{2}$-type granites. The substantial volume of pyroclastic rocks (especially rheoignimbrites) and effusive rocks (subordinate) with associated epizonal granitic bodies is similar to that of caldera complexes. These granites are the plutonic equivalents of the Iricoumé volcanic rocks. Their emplacements were associated to an extensional regime that led to the collapse of the caldera (Ferron et al., 2010).

The Urupi Formation consists of fluvial-eolian sandstones with pyroclastic interbeds (Veiga et al., 1979) that have a minimum age of $1780 \mathrm{Ma}$ (Santos et al., 2002). Dated zircons from two cineritic tuff interbeds yielded $\mathrm{Pb}-\mathrm{Pb}$ ages of $1882 \pm 7.1 \mathrm{Ma}$ and $1825 \pm 3.9 \mathrm{Ma}$, respectively (Bastos Neto et al., unpublished results). The Madeira, Água Boa, and Europa granites belong to the Madeira Suite (Fig. 10) described below. The Quarenta Ilhas Formation (zircon $\mathrm{U}-\mathrm{Pb}$ age of $1780 \pm 3 \mathrm{Ma}$, Santos et al., 2002) includes tholeiitic basic rocks. The Seringa Formation (Veiga et al., 1979) is 
composed of alkaline flows and dikes from the Mesoproterozoic (K/ Ar from $1079 \pm 18$ Ma to $1090 \pm 13$ Ma, Araujo Neto and Moreira, 1976).

\subsection{Madeira Suite and associated primary ore deposits}

The Madeira granite contains four facies (Fig. 11). The older facies is an amphibole-biotite syenogranite (rapakivi granite). The biotite-alkali-feldspar granite facies is peraluminous, equigranular, and locally porphyritic. The alkali feldspar hypersolvus porphyritic granite facies has phenocrysts in a fine- to medium-grained matrix composed dominantly of K-feldspar and quartz. According to Costi (2000), the hypersolvus granite and the albite-enriched granite (AEG) were emplaced simultaneously, then interacted and intruded into the older facies. The AEG has a core and a border facies. The AEG core is a subsolvus granite, porphyritic to seriate in texture, fine- to medium-grained, and composed of quartz, albite, and Kfeldspar in nearly equal proportions (25-30\%). The accessory minerals are cryolite (5\%), polylithionite (4\%), green-brown mica (3\%), zircon (2\%), and riebeckite (2\%). Pyrochlore, cassiterite, xenotime, columbite, thorite, magnetite, and galena occur in minor proportions. The AEG border is a peraluminous granite with the same texture types and essential mineralogy as the AEG core except for iron-rich minerals, which have almost completely disappeared because of an autometasomatic process, together with the presence of fluorite instead of cryolite (Costi et al., 2000, 2009). The Madeira deposit corresponds to the AEG. This is a world-class deposit of 164 million tons of disseminated ore with a grade of $0.17 \%$ Sn (cassiterite). Niobium and Ta (both in pyrochlore and columbite) are exploited as by-products. The potential byproducts of the disseminated ore are $\mathrm{F}$ (cryolite), $\mathrm{Y}$ and HREE [xenotime and gagarinite(Y)], $\mathrm{Zr}$ and $\mathrm{U}$ (zircon), Li (polylithionite), and Th (thorite). In addition, in the central portion of the Madeira deposit, there is a massive cryolite deposit (MCD) of ten million tons with a grade of $31.9 \%$ cryolite $\left(\mathrm{Na}_{3} \mathrm{AlF}_{6}\right)$ (Minuzzi et al., 2006; Bastos Neto et al., 2005, 2009).

The Água Boa granite (Fig. 11) contains four facies. The older facies is a coarse-grained hornblende-biotite syenogranite (rapakivi granite, Daoud and Antonietto, 1985). The next two facies are a finegrained porphyritic biotite syenogranite and a coarse- to mediumgrained biotite-alkali-feldspar granite. The younger facies is a topaz-bearing porphyritic biotite granite (Lenharo, 1998). In the Água Boa granite, there are two types of mineralization. The greisens are associated with virtually all facies of the pluton, forming continuous and homogeneous levels with thickness up to $5 \mathrm{~m}$. The high temperature greisens are composed of quartz, topaz, syderophyllite and sphalerite ( \pm cassiterite, pyrite, chalcopyrite, zircon, fluorite, siderite, and $\mathrm{Nb}$-anatase). The low temperature greisens consist essentially of quartz, phengite, and chlorite, with subordinate cassiterite, pyrite, galena, sphalerite, zircon, rutile, onyx, and fluorite. The tin-bearing sodic episyenites are composed essentially of albite and low modal content of quartz, and formed through the following stages: (a) albitization of K-feldspar; (b) cavities formation by dissolution of magmatic quartz; (c) filling of cavities by albite, chlorite, phengite, and cassiterite; (d) late quartz and cassiterite deposition (Borges et al., 2003, 2009, 2014).

According to Lenharo (1998), all the facies of the Madeira and Água Boa granites were formed from different mixtures of crustal and mantle sources, with prominent crustal contribution in all cases. The AEG origin relates to a specialized syenite or to the Europa peralkaline granite. According to Costi (2000), the AEG has either a mafic source with a short crustal residence time or a mantle source and was likely formed from a magma different from the magma that generates the earlier facies of the Madeira granite. Alternatively, Costi (2000) proposed that all of the facies of the
Madeira granite came from the same magma and that the Fenrichment depolymerized the magma and reversed the crystallization trend from peraluminous with increasing silica to peralkaline with decreasing silica, thus forming the AEG. According to Costi et al. (2009), the F-rich peralkaline melt that produced the AEG was most likely the result of a phase-separation process, or immiscibility, similar to that described by Thomas et al. (2006).

The Europa granite, dated at $1831 \pm 11$ and $1839 \pm 6.2$ Ma (Bastos Neto et al., 2014), was the first pluton of the Madeira Suite to be emplaced. The Madeira granite, elongated in a NE-SW direction (Fig. 11), aligns with the Água Boa granite and the Pedreira granite (ca. 1880 Ma, Mapuera Suite). Within the Água Boa granite (Fig. 11), even the latest facies occurs elongated in a NE-SW direction. However, in the Madeira granite, the AEG, which is the most recent facies, has $\mathrm{N}-\mathrm{S}$ orientation. The first ages obtained for the Água Boa granite that are consistent with contact relationship between the facies within the body $(1824 \pm 24 \mathrm{Ma}$ in the biotite granite facies and $1816 \pm 20 \mathrm{Ma}$ in the topaz granite facies, Bastos Neto et al., 2014) indicate that this pluton is approximately synchronous with the early facies of the Madeira granite. The AEG was crystallized between $1822 \pm 22$ Ma (Bastos Neto et al., 2014) and $1794 \pm 19$ Ma (Lenharo, 1998), with a strong hydrothermal process occurring at $1782 \pm 4 \mathrm{Ma}$ (Lenharo, 1998). Bastos Neto et al. (2014) suggest a model of AEG emplacement dominated by a N-NEtrending shortening related to a left-lateral motion along a NE-SW corridor, in the position of Riedel shear. This corridor previously controlled the Pedreira granite (Mapuera Suite, approximately $1880 \mathrm{Ma}$ ), the Água Boa granite and the early facies of Madeira granite (ca. $1830 \mathrm{Ma}$ ); the existence of a substantial time lag between the emplacement of the early facies of the Madeira granite and the AEG may provide evidence that the AEG localization within the Madeira granite is fortuitouos.

\section{Rondônia Tin Province}

The Rondônia Tin Province (RTP; Fig. 12; Isotta et al., 1978) is located in the Rio Negro-Juruena Province (1.80-1.55 Ga), in the Southwestern Amazonian Craton (SWAC). Tin mineralization has been responsible for 270,000 tons of $\mathrm{Sn}$ in concentrate, up to 2012, mostly mined from alluvial sources, since the discovery of the first cassiterite occurrences in 1952. Recoverable resources of W, Ta, Nb, and topaz are significant in some districts. Proterozoic anorogenic granites (Fig. 12), were recognized in the late 1960's and characterized as rapakivi granites. Bettencourt et al. (1999) identified seven rapakivi suites, which were temporarily correlated to the development of three tectonic provinces in the SWAC: Rio NegroJuruena (1.80-1.55 Ga), Rondonian-San Ignácio (1.56-1.30 Ga), and Sunsás-Aguapeí (1.20-0.95 Ga) (Tassinari and Macambira, 1999; Bettencourt et al., 2010; J.B.G. Teixeira et al., 2010; W. Teixeira et al., 2010).

The primary rare and base-metal mineralization ( $\mathrm{Sn}, \mathrm{W}, \mathrm{Nb} \pm \mathrm{Ta}$, $\mathrm{Be}, \mathrm{Zn}, \mathrm{Cu}, \mathrm{Pb}$ ) is closely associated with the three youngest suites, more specifically to peraluminous tin-granites, as follow: São Lourenço-Caripunas (1.31-1.30 Ga), Santa Clara (1.08-1.07 Ga) and Younger Granites of Rondônia $(0.99-0.97 \mathrm{Ga})$ intrusive suites. Since the 1990's, a number of detailed studies and reviews on rare-metal metallogeny have been published by Bettencourt et al. (1999, 2005), Leite (2002), Sparrenberger (2003), Souza (2003), V.S. Souza et al. (2005) and others.

We will present selected polymetallic deposit types: 1 - Santa Bárbara ( $\mathrm{Sn}-\mathrm{W})$, a mineralized cupola and bed-like greisen bodies, 2 - Oriente Novo (Sn, W, Nb, Ta, Be), as lode/stringer, stockwork and disseminated deposit type, and 3 - Bom Futuro ( $\mathrm{Sn} \pm \mathrm{W}, \mathrm{Zn}, \mathrm{Cu}$, $\mathrm{Pb}$ ) as example for pegmatite, quartz vein, and greisen deposits. 


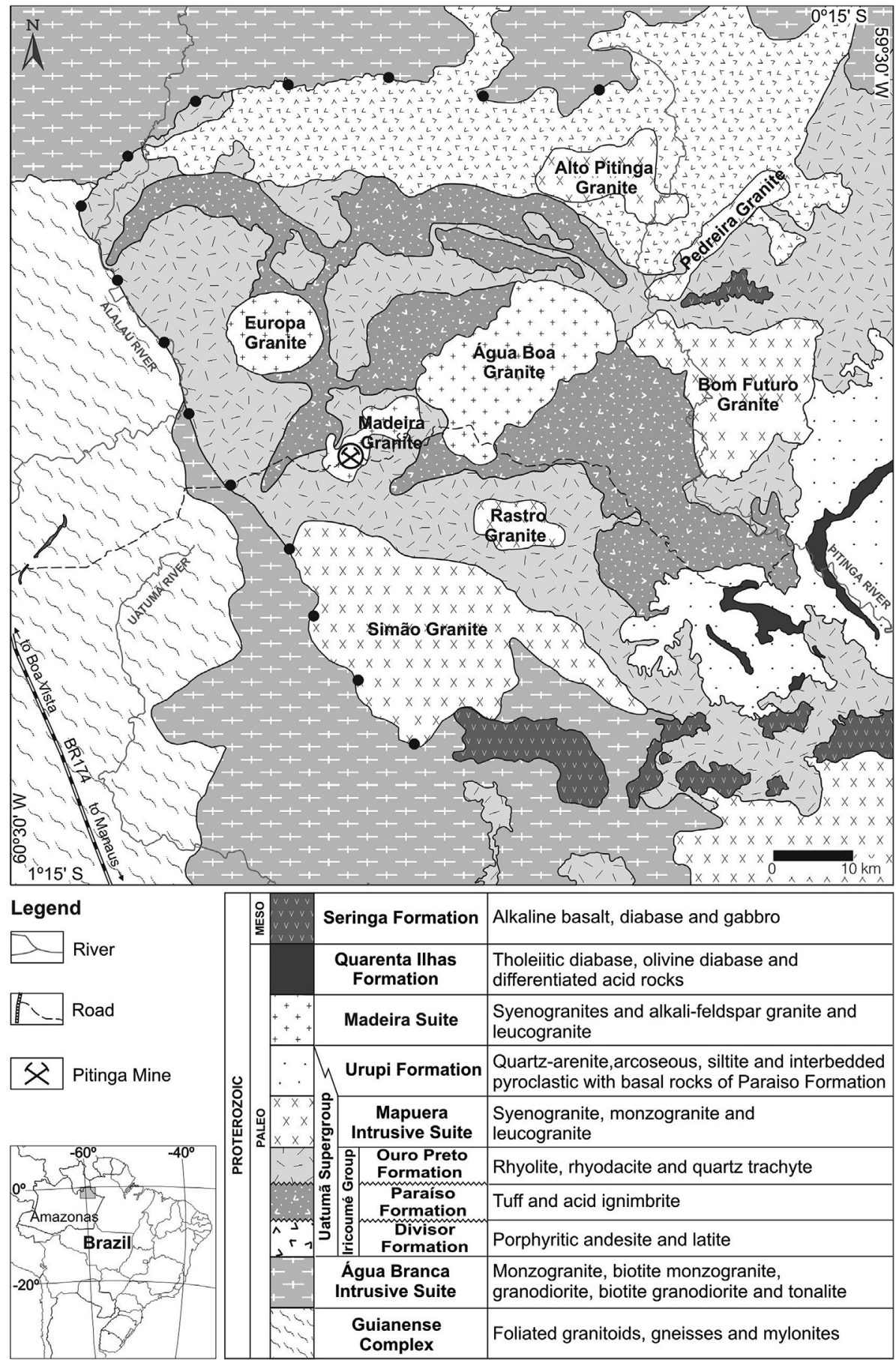

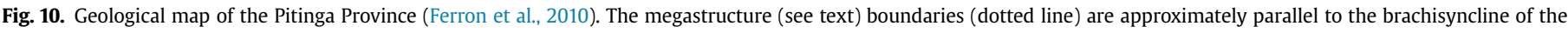
Pitinga River, which is outlined by the Quarenta Ilhas formation.

\subsection{The São Lourenço-Caripunas Intrusive Suite (SLCIS)}

The São Lourenço-Caripunas Intrusive Suite (1.31-1.30 Ga) crops out in a northeastern direction along the Madeira River (Fig. 12). It represents A-type magmatism caused by late to post-collisional processes following upon major collision at ca. 1.34-1.32 Ga, related to the Rondonia-San Ignacio $(1.56-1.30 \mathrm{Ga})$ province and includes juvenile material, as well as melting derived from evolved continental crust. The São Lourenço-Caripunas massif is composed of plutonic and subvolcanic rocks mainly of granitic composition
(Bettencourt et al., 1999; Leite et al., 2014). They contain biotite and hornblende as the main mafic minerals, but clinopyroxene and fayalite also occur in some granitic facies. In the São Lourenço region, porphyritic hornblende-biotite syenogranites, biotite-hornblende quartz-syenites and even-grained biotite granites are common, besides rhyolite porphyry, and gabbro. The granites show geochemical characteristics of ferroan, alkali-calcic, A-type and within-plate granites. The majority of the granites are metaluminous, but peraluminous granites, host of the primary tin deposits, occur in the São Lourenço region. Primary tin deposits are 


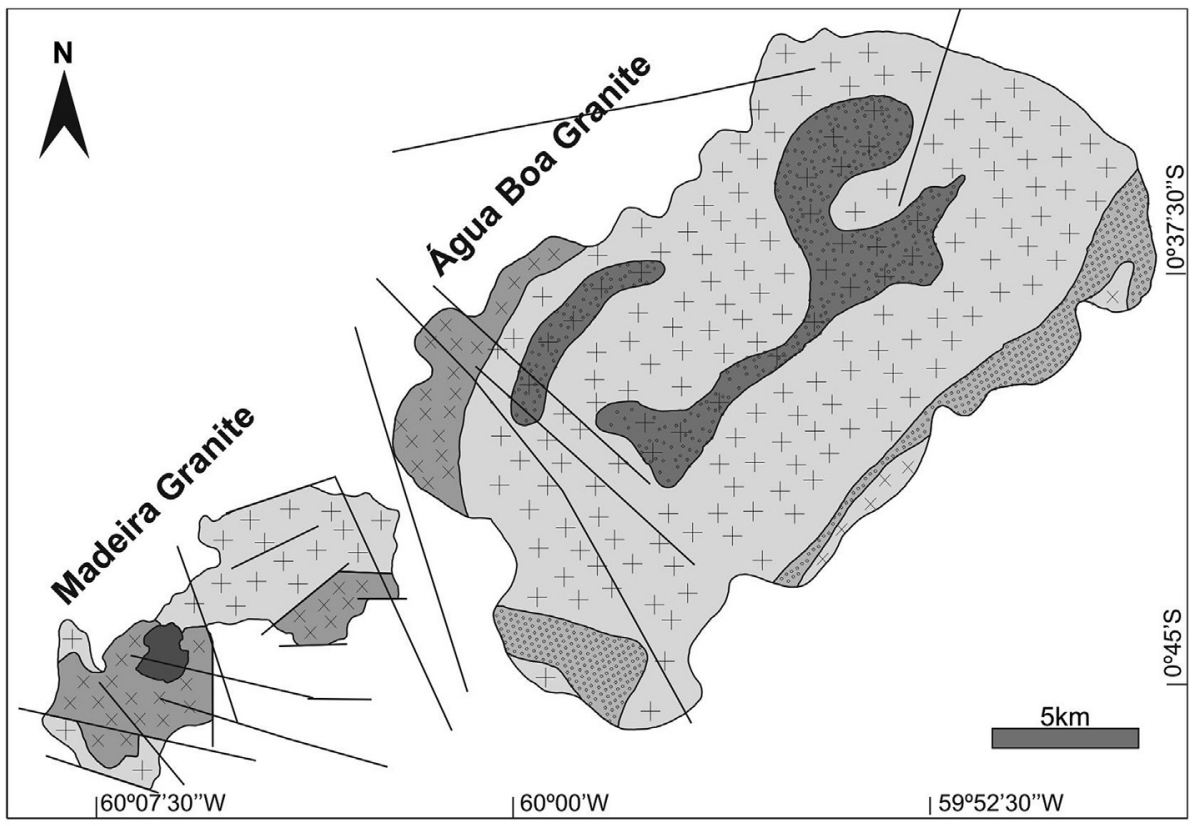

Água Boa Granite

Porphyritic topaz granite

Porphyritic syenogranite

Biotite granite

Amphibole-biotite syenogranite
Madeira Granite

Albite-enriched granite and porphyritic hypersolvus granite (not differentiated)

Biotite granite

Amphibole-biotite syenogranite

Iricoumé Group

Fig. 11. Geological map of the Madeira and Água Boa granites (Costi, 2000).

spatially related to even-grained biotite granites mostly as greisen bodies with cassiterite and quartz veins with cassiterite, minor wolframite, and $\mathrm{Cu}-\mathrm{Zn}-\mathrm{Pb}-\mathrm{Fe}$ sulfides. The SLCIS ore-host rocks have positive $\varepsilon_{\mathrm{Nd}(\mathrm{t})}$ of +0.04 to +2.01 are juvenile in character, and Sm-Nd $\mathrm{T}_{\mathrm{DM}}$ model ages range from 1.59 to $1.67 \mathrm{Ga}$, which means that some old crustal material was involved and the sources were isotopically homogeneous.

\subsection{The Santa Clara (SCIS) and Younger Granites of Rondônia (YGRIS) intrusive suites}

Both suites (Fig. 12) are linked to the evolution of the SunsásAguapeí tectonic province $(1.20-0.95 \mathrm{Ga})$, characterize the intracratonic stage of magmatism, which mostly occurred in major EW-NW trending transpressional to extensional structures resulted from mantle and crust-derived melt, and comprise three compositional rock associations sharing ferroan, A-type and within-plate granite geochemical characteristics. An older subsuite is alkali-calcic and marginally peraluminous. The two other younger sub-suites are volumetrically minor. The first exhibits alkalic and peralkaline features, and the second shows alkali-calcic and peraluminous compositions. The peraluminous sub-suites contain biotite syeno- and alkali-feldspar granites, Limica \pm topaz alkali-feldspar granite and rhyolite, and topaz-quartz rocks.

The rare and base- metal primary deposits are spatially and temporally associated with these late-stage peraluminous subsuites mainly as: cassiterite (columbite-tantalite) disseminated in the Li-mica \pm topaz alkali-feldspar granite, greisen bodies with cassiterite, quartz \pm topaz veins with cassiterite and wolframite, and veinlets with quartz and $\mathrm{Cu}-\mathrm{Zn}-\mathrm{Pb}-\mathrm{Fe}$ sulfides (Bettencourt et al., 2005). Important pegmatite bodies with Li-mica, topaz and cassiterite occur in Bom Futuro mine in the domain of the YGRIS (Dias et al., 2013).

Bettencourt et al. (2005) report ${ }^{40} \mathrm{Ar} /{ }^{39} \mathrm{Ar}$ plateau ages for zinnwaldite and muscovite from the Santa Barbara and Bom Futuro deposits ( $959 \pm 4$ to $994 \pm 3 \mathrm{Ma}$ ) and for muscovite of mica greisen from the Potosi deposit $(1053 \pm 3 \mathrm{Ma}$; Fig. 12). Leite (2002) also report $\mathrm{K}-\mathrm{Ar}$ ages obtained after $\mathrm{Li}-\mathrm{Fe}$ micas of $1006 \pm 17$ to $976 \pm 30 \mathrm{Ma}$ from greisen and quartz vein from Oriente Novo, and Rio Branco deposits, and of $961 \pm 19$ and $969 \pm 27$ Ma for greisen and quartz-vein from the Santa Bárbara and Bom Futuro deposits. The data suggest an Ar loss for the Oriente Novo and Rio Branco deposits due to thermal effect caused by the emplacement of the neighboring YGRIS.

\subsection{Tin ore deposits}

\subsubsection{Santa Bárbara deposit}

The Santa Bárbara massif is a stock with a diameter of $7 \mathrm{~km}$ and includes three subsolvus granite units (Figs. 12 and 13): (1) an early metaluminous porphyritic syenogranite; (2) a peraluminous porphyritic syenogranite, and (3) a central porphyritic albitemicrocline granite (tin granite).

Ages of 1 and 2 granite units by $\mathrm{U}-\mathrm{Pb}$ monazite are $993 \pm 5 \mathrm{Ma}$ and $989 \pm 13 \mathrm{Ma}$, respectively. SHRIMP $\mathrm{U}-\mathrm{Pb}$ zircon ages of the 


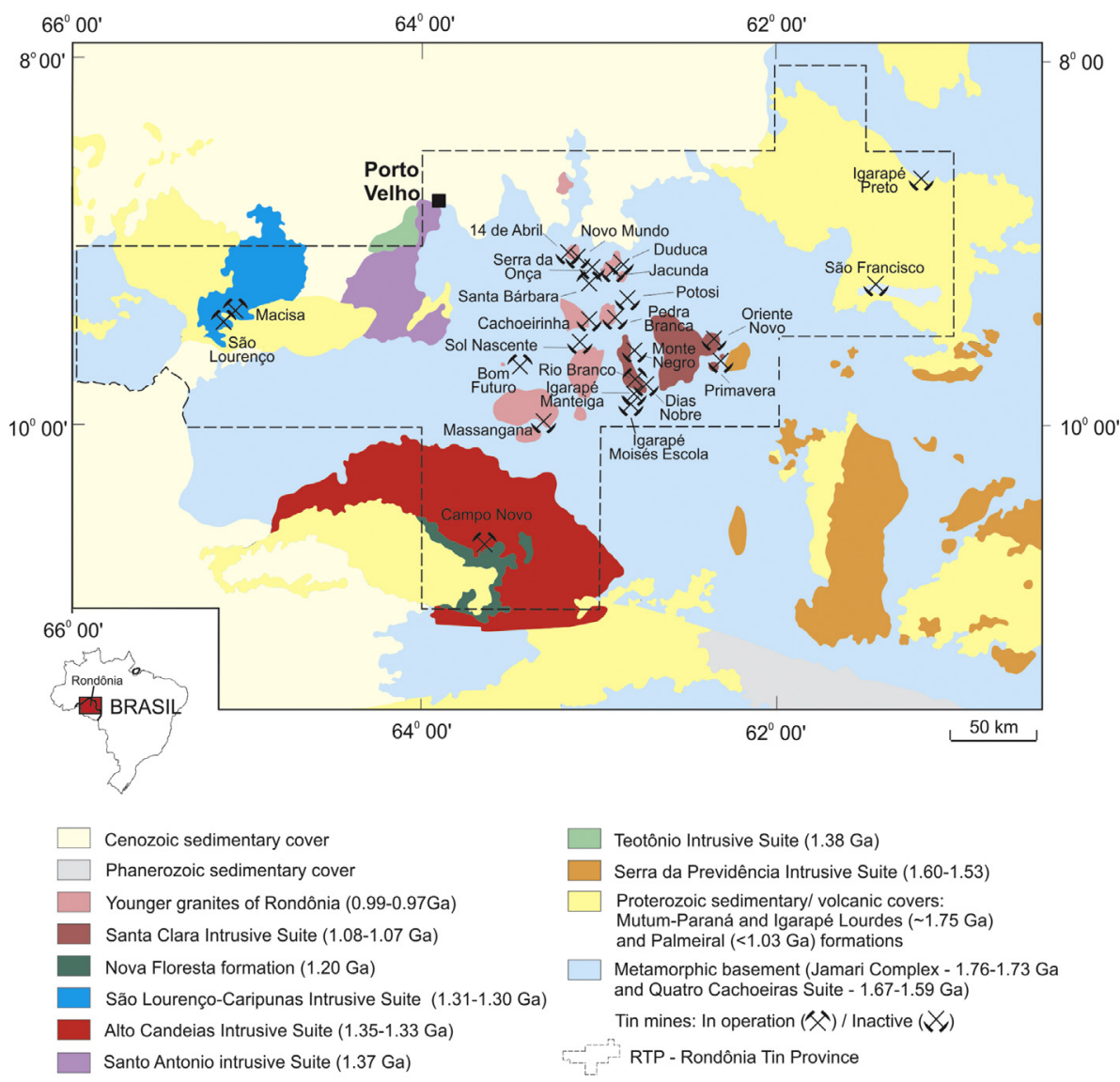

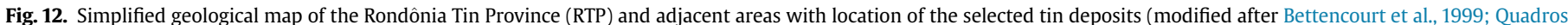
and Rizzoto, 2007).

Santa Barbara facies (tin granite) yielded a weighted-mean age of $978 \pm 13 \mathrm{Ma}$

The tin granite encompasses two peraluminous granitic facies: a medium-grained porphyritic albite-microcline granite and a finegrained equigranular to porphyritic albite-microcline granite; the later occupies the apical part of the cupola. The main minerals are quartz, albite, microcline and zinnwaldite; accessory minerals comprise magmatic fluorite and topaz, monazite, zircon, xenotime, thorite, columbite, cerianite, and cassiterite. They are of magmatic origin and were affected by subsolidus reactions and hydrothermal alteration, represented by greisenization, albitization, silicification, muscovitization, and argillization during late-magmatic hydrothermal and post-magmatic stages. These granites are characterized by high $\mathrm{SiO}_{2}, \mathrm{~K}_{2} \mathrm{O}, \mathrm{Na}_{2} \mathrm{O}, \mathrm{Fe}_{2} \mathrm{O}_{3} /\left(\mathrm{Fe}_{2} \mathrm{O}_{3}+\mathrm{MgO}\right)$, $\mathrm{Sn}, \mathrm{Rb}, \mathrm{Ce}, \mathrm{Nb}$, Ga, Y, F, Li, U and Th contents (Sparrenberger, 2003) and low concentrations of $\mathrm{CaO}, \mathrm{MgO}, \mathrm{TiO}_{2}, \mathrm{Al}_{2} \mathrm{O}_{3}, \mathrm{Ba}, \mathrm{Sr}$ and $\mathrm{Zr}$. They also show high total REE contents, are slightly enriched in LREE, and exhibit a strong negative Eu anomaly. The albite-microcline granite shows more evolved patterns characterized by higher Ga (46 ppm), Li (366 ppm), Ta (34 ppm), Y (914 ppm), total REE (1927x chondrite), than the other tin-specialized granites (Sparrenberger, 2003).

The Santa Bárbara deposit (Figs. 12 and 13) covers an area of ca. $500 \mathrm{~m}$ by $150 \mathrm{~m}$. The tin deposit encompasses two styles of mineralization: (1) bed-like cassiterite-bearing topaz-zinwaldite-quartz greisen bodies, up to $40 \mathrm{~m}$ thick, and albitized granites; and (2) a vein-veinlet/stockwork, encompassing brittle fracture zones containing topaz-zinnwaldite-quartz-greisen veins with cassiterite-wolframite, quartz-cassiterite veins, muscovite veins, and late kaolinite stockwork/veinlets.
The early inclusions are represented by: (1) low salinity (5-12 wt.\% $\mathrm{NaCl}$ eq. aqueous fluids homogenizing at $340-390{ }^{\circ} \mathrm{C}$; and (2) low salinity ( $0-3 \% \mathrm{wt} . \% \mathrm{NaCl}$ eq) aqueous fluid inclusions, which homogenize at $320-380{ }^{\circ} \mathrm{C}$. Cassiterite, wolframite, columbite-tantalite, scheelite assemblages accompany these fluids. The late fluid has lower salinity $(0-3 \mathrm{wt} . \% \mathrm{NaCl}$ eq.) and characterizes the late-barren quartz, muscovite and kaolinite veins.

Fluid evolution model for the quartz-pods, bedded-greisen, greisen stockwork, and quartz-cassiterite veins, comprises three trends of evolution: trend I - immiscibility trend of an originally aqueous-carbonic fluid associated with $\mathrm{CO}_{2}$ degassing, at $\mathrm{T}=500{ }^{\circ} \mathrm{C}$ and $\mathrm{P} \sim 500$ bar; trend $\mathrm{II}-$ dilution of the original $\mathrm{CO}_{2}$ poor aqueous-carbonic fluid accompanied by gass loss at $\mathrm{T}=350-370^{\circ} \mathrm{C}$ and $\mathrm{P} \sim 200 \mathrm{bar}$; and trend III characterized by the effect of dilution of the original fluid by less saline and cooler water from 350 to $370{ }^{\circ} \mathrm{C}-130{ }^{\circ} \mathrm{C}$ at $\sim 10$ bar (Sparrenberger, 2003; Bettencourt et al., 2005).

Oxygen isotopes indicate temperatures of the order of $570{ }^{\circ} \mathrm{C}$ and $500{ }^{\circ} \mathrm{C}$ for pegmatoid phase and bedded greisen bodies. The crystallization temperature for the quartz-cassiterite veins is $415{ }^{\circ} \mathrm{C}$. The isotope composition for the water $\left(\delta^{18} \mathrm{O}_{\mathrm{H}_{2} \mathrm{O}}=3.8-10.4 \%\right.$ ), in equilibrium with metasomatites, plot in the magmatic water field (Taylor, 1997), except the muscovitization $\left(\delta^{18} \mathrm{O}_{\mathrm{H}_{2} \mathrm{O}}=-6.8 \%\right.$ ) and silicification II products $\left(\delta^{18} \mathrm{O}_{\text {quartz }}=3.8 \%\right.$ ), which suggest mixture with aqueous low-salinity $(0-3 \mathrm{wt} \% \mathrm{NaCl}$ eq.) meteoric fluids.

\subsubsection{Oriente Novo deposit}

The Oriente Novo massif (Fig. 12) occupies $80 \mathrm{~km}^{2}$ and consists 
A
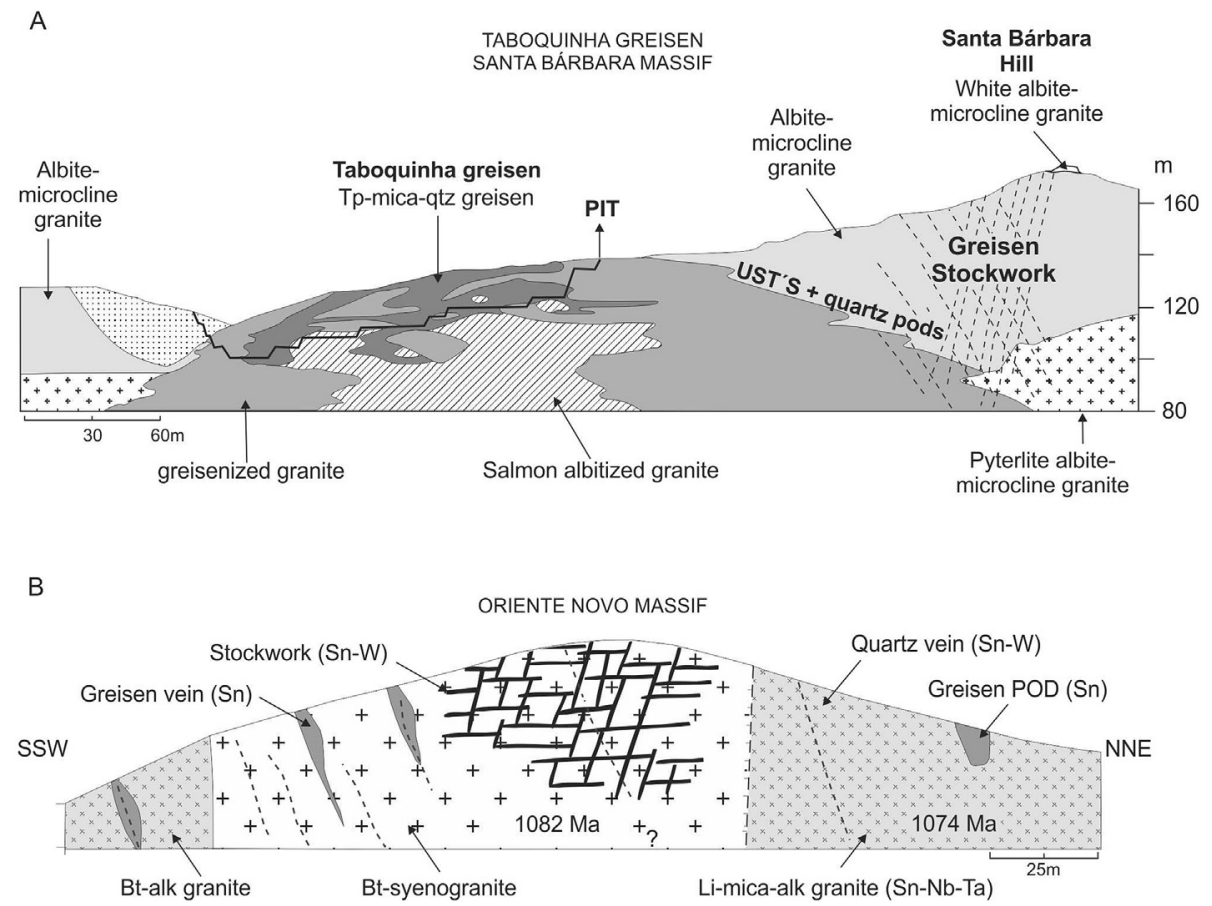

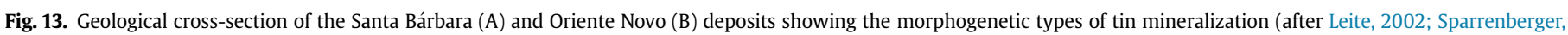
2003; Bettencourt et al., 2005).

of a central porphyritic biotite ( \pm hornblende) monzogranite. It is surrounded by a medium-grained and fine-grained porphyritic biotite syenogranites and muscovite microgranite.

The primary rare-metal $\mathrm{Sn}(\mathrm{W}, \mathrm{Ta}, \mathrm{Nb}, \mathrm{Be})$ deposits are associated with syderophyllite-alkali feldspar granite and rhyolite porphyry (Leite, 2002). The zinnwaldite-alkali feldspar and rhyolite porphyry show porphyritic texture and exhibit poikilitic microcline and quartz megacrystals $(<0.5 \mathrm{~cm})$ dispersed in an albitedominated fine- to very fine-grained matrix. Zinnwaldite is present and includes zircon, fluorite, rutile, cassiterite, and columbitetantalite crystals. The syderophyllite-alkali-feldspar granite and alaskite are high in $\mathrm{SiO}_{2}, \mathrm{~F}, \mathrm{Rb}, \mathrm{U}, \mathrm{Y}$, and low in $\mathrm{TiO}_{2}, \mathrm{Al}_{2} \mathrm{O}_{3}, \mathrm{Fe}_{2} \mathrm{O}_{3}$ total, $\mathrm{MgO}, \mathrm{CaO}, \mathrm{P}_{2} \mathrm{O}_{5}, \mathrm{Ba}, \mathrm{Sr}$, and $\mathrm{Eu}$, whereas the zinnwalditealkali-feldspar granite and rhyolite porphyry are low in $\mathrm{SiO}_{2}, \mathrm{TiO}_{2}$, $\mathrm{Fe}_{2} \mathrm{O}_{3}$ total, $\mathrm{CaO}, \mathrm{K}_{2} \mathrm{O}$, and high in $\mathrm{Al}_{2} \mathrm{O}_{3}, \mathrm{Na}_{2} \mathrm{O}, \mathrm{Li}, \mathrm{Rb}, \mathrm{Ga}, \mathrm{Nb}, \mathrm{Sn}$, and Ta (Leite, 2002). These geochemical characteristics match those of rare-metal peraluminous granites (e.g. Pollard, 1989a).

The primary deposit occupies an area of $\sim 1.5 \mathrm{~km}^{2}$. Major styles of mineralization consist of three distinct groups (Figs. 12 and 13): (1) stockwork of vein/veinlets of greisen with cassiterite and of quartz with cassiterite and wolframite hosted by older medium-grained porphyritic biotite syenogranite greisen; (2) disseminated cassiterite and columbite-tantalite in the zinnwaldite alkali-feldspar granite with cassiterite-bearing greisen-pods; and (3) sub-parallel veins/veinlets of greisen with cassiterite, and of quartz with cassiterite and wolframite, having a general strike of $\mathrm{N} 30-50 \mathrm{E}$, and a dip of 50-80 SE. The stockwork mineralization is interpreted to be genetically related to the syderophyllite-alkali feldspar granite and alaskite, whereas the disseminated, endogreisen and subparallel vein/veinlet mineralization styles are related to the zinnwaldite-alkali feldspar granite and rhyolite porphyry (Leite, 2002).

Two types of primary fluid inclusions are found in topaz and quartz. Type I aqueous carbonic fluid inclusions $\left(\mathrm{H}_{2} \mathrm{O} \pm \mathrm{CO}_{2}-\mathrm{CH}_{4}-\mathrm{NaCl}\right)$ subdivided into two sub-types, both showing low to moderate salinity $(0.4-13.8 \mathrm{wt} . \% \mathrm{NaCl}$ eq.) and the total homogenization takes place at $190-440{ }^{\circ} \mathrm{C}$. Type - II aqueous
$\mathrm{CO}_{2} \pm \mathrm{H}_{2} \mathrm{O}$ rich fluid inclusions contain small amounts of $\mathrm{CO}_{2}$ in addition to water-rich fluid $\left(\mathrm{H}_{2} \mathrm{O}-\mathrm{NaCl}\right) \mathrm{CO}_{2}$, have low to moderate salinities (2.4-14.1 wt.\% $\mathrm{NaCl}$ eq.), but show lower homogenization temperatures $\left(100-340^{\circ} \mathrm{C}\right)$. Type I and II $\left(\mathrm{Th}>240^{\circ} \mathrm{C}\right)$ inclusions have resulted from effervescence of an aqueous-carbonic fluid derived from a late-magmatic parental fluid phase. Type II $\left(\mathrm{Th}<240^{\circ} \mathrm{C}\right)$ inclusions are products of a mixture of a magmatic $\mathrm{CO}_{2}$-bearing water-rich fluid and some meteoric water in all styles of mineralization.

Trapping conditions of Type Ia and Ib immiscible fluids, took place between 240 and $370{ }^{\circ} \mathrm{C}$ and $1.0-2.4 \mathrm{kbar}$, which indicate a depth of emplacement of the post-magmatic hydrothermal deposits between $4 \mathrm{~km}$ and $10 \mathrm{~km}$, compatible with a transitional hypabissal to plutonic environment.

Oxygen and hydrogen isotope data (Leite, 2002; Bettencourt et al., 2005) indicate that: 1 - the water in equilibrium with zinnwaldite from alkali-feldspar granite $\left(\delta^{18} \mathrm{O}_{\mathrm{H}_{2} \mathrm{O}}=8.9 \%\right.$; $\delta \mathrm{D}_{\mathrm{H}_{2} \mathrm{O}}=-6.9 \%$ ) overlaps the field of the typical magmatic water, 2 - the calculated $\delta^{18} \mathrm{O}_{\mathrm{H}_{2} \mathrm{O}}$ values of fluids in equilibrium with zinnwaldite from greisen (7.4\%o and $7.7 \%$ ) and quartz vein $(7.5 \% 0)$ plot in field of magmatic water, and, 3 - the calculated $\delta \mathrm{D}$ values from zinnwaldite from greisen $(-66 \%$ and $-76 \% 0)$ and quartz vein $(-87 \%)$ are low and suggest a meteoric component in the hydrothermal fluids responsible for the formation of greisen and quartz vein.

\subsubsection{The Bom Futuro deposit}

The Bom Futuro tin mine comprises the Bom Futuro and Palanqueta hills. The first includes anorogenic Grenvillian topaz granite porphyry and topaz rhyolite porphyry dikes associated with two breccia pipes, besides of trachyte and syenite porphyry dikes. The granitic and syenitic rocks belong to the YGRIS (998-974 Ma; Bettencourt et al., 1999), and were intruded in gneisses and amphibolites ( $>1330 \mathrm{Ma}$ ). Two phases of tin related to pegmatite and quartz veins mineralization (Dias et al., 2013), have ${ }^{40} \mathrm{Ar} /{ }^{39} \mathrm{Ar}$ plateau ages of $994 \pm 3 \mathrm{Ma}$ and $993 \pm 3 \mathrm{Ma}$ (Bettencourt et al., 2005). 
The older pegmatite bodies occur as lens and veins, have a few meters in width, and a few ten to hundred meters in length and define a ring pattern surrounding the hill, dipping outward at $30^{\circ}$ to $50^{\circ}$. Three main internal zones are recognized: quartz and topaz zone, K-feldspar and zinnwaldite zone, and granitic zone. Cassiterite, stannite and base metal sulfides are mainly associated with the quartz and topaz zone (Dias et al., 2013).

Fluid inclusion and oxygen isotopic studies in cassiterite and quartz indicate a minimum temperature of $400{ }^{\circ} \mathrm{C}$ for the mineralization (Souza, 2003). The younger pegmatite and quartz veins ( $<1.5 \mathrm{~m}$ thick) crosscut all the lithologic units, forming a subparallel system with the same attitude as the older ones and, locally, as stockworks. These veins are zoned, with zinnwaldite occurring in the border and K-feldspar, quartz and topaz, or quartz and topaz or quartz in the core. The cassiterite occurs in quartz and topaz enriched portions.

The Palanqueta hill $\left(<1 \mathrm{~km}^{2}\right)$ represents the apical part of a zoned and multiphase granitic stock. A biotite sienogranite and six distinct topaz granitic facies are recognized (Leite et al., 2005). Major and trace elements behavior suggest the following magmatic evolutionary trend for the topaz granitic facies: equigranular topaz granite $\rightarrow$ porphyritic topaz granite $\rightarrow$ topaz microgranite $\rightarrow$ topaz granite porphyry. The most distinct feature is the decrease in REE (170.54-31.79 ppm) and $\mathrm{Al}_{2} \mathrm{O}_{3}(13.71-12.74 \%)$ contents, and $\mathrm{La}_{\mathrm{N}} /$ $\mathrm{Yb}_{\mathrm{N}}(2.45-0.27)$ and $\mathrm{Zr} / \mathrm{Hf}(12-7)$ ratios, as well as the increase in $\mathrm{Na}_{2} \mathrm{O} / \mathrm{K}_{2} \mathrm{O}(1.54-2.08)$ ratios and increase in $\mathrm{SiO}_{2}(75.77-77.37 \%)$ contents. Tin-mineralized greisen occurs as pipelike bodies in and around the topaz granite porphyry facies. The greisen pipes (few meters in diameter and ten meters in length) are zoned and include quartz, Li-mica, and topaz, with fluorite, cassiterite, wolframite, pyrite, and base metal sulfides as accessory minerals. $\mathrm{U}-\mathrm{Th}-\mathrm{Pb}$ dating of hydrothermal monazite yielded an age of $997 \pm 48 \mathrm{Ma}$ (V.S. Souza et al., 2005), and fluid inclusion and oxygen isotopic studies in cassiterite and quartz indicate a minimum temperature of $400{ }^{\circ} \mathrm{C}$ for the mineralization (Souza, 2003).

\section{Discussions}

\subsection{Archean and Paleoproterozoic iron oxide-copper-gold and related deposits of the Carajás Mineral Province}

The distinctive geological evolution of the Rio Maria and Carajás domains has remarkable implications for metallogenesis of the Carajás Mineral Province. In the Rio Maria Domain, the expected variability for orogenic gold deposits is found. The granitoid-hosted Cumaru gold deposit (e.g. Cumaru Granodiorite; ca. $2.82 \mathrm{Ga}$; Santos et al., 1998) may reflect that both magma and fluids represent inherent products of the thermal evolution of orogens (Groves et al., 1998; Goldfarb et al., 2001). Geochronological data regarding the orogenic gold deposits in the Rio Maria Domain are scarce, but possibly these deposits were formed during the last tectonothermal event preceding the cratonization of the Rio Maria Domain at ca. $2.86-2.80 \mathrm{Ga}$. This coincides with a metallogenetic epoch (ca. 2.8 to $2.55 \mathrm{Ga}$; Goldfarb et al., 2001) favorable for the formation of orogenic gold deposits, as recognized in greenstone sequences in other Archean cratons (e.g. Yilgarn, Australia, Dharwar, India, Slave, Canada, San Francisco, Brazil, and Tanzania).

The Neoarchean magmatism, crustal reworking and development of major shear zones, only recognized in the Carajás Domain, allowed the circulation of hydrothermal fluids on a large scale in Carajás. However, it is still controversial whether the two domains shared a common evolution before the Neoarchean (Dall'Agnol et al., 2006) or were amalgamated during the Neoarchean (ca. 2.74 Ga; J.B.G. Teixeira et al., 2010; W. Teixeira et al., 2010) or Mesoarchean (ca. 2.86 Ga; Tavares, 2015).
The geodynamic setting of the province may represent a first order control on the IOCG formation, because large $\mathrm{E}-\mathrm{W}$-trending translithospheric shear zones may represent ancient suture zones. In those zones, early subduction may cause volatile-rich and possibly metal-enriched metasomatism of the subcontinental lithospheric mantle and underplate with important consequences to the magmatism, up to 100 Ma younger. This could be important to explain the features of the (ca. $2.74 \mathrm{Ga}$ ?) A-type magmatism and magmatic fluids associated with IOCG deposits (Hayward and Skirrow, 2010; Groves et al., 2010). On the other hand, Teixeira et al. (2015) propose that enrichment in compatible (Fe, Ni, Mg, $\mathrm{Cu}, \mathrm{Cr}, \mathrm{Co}$ ) and incompatible elements (Na, K, F, Cl and LREE) present in all IOCG deposits can be also a result of plume interaction in cratonic lithosphere rather than enrichment by slab components during previous subduction.

Precise geochronological data permit the identification of multiple hydrothermal IOCG events in the Carajás Domain (ca. 2.70-2.68 Ga; ca. 2.57-2.42 Ga, and ca. 1.88 Ga; Réquia et al., 2003; Tallarico, 2003; Tallarico et al., 2005; Melo, 2014; Moreto et al., 2015a, 2015b).

The Archean IOCG hydrothermal systems are hybrid and distinct deposits reveal a variable proportion of magmatic (mantelic?) and externally-derived fluids, as recorded by stable isotope $(\mathrm{O}, \mathrm{H}, \mathrm{S}, \mathrm{Cl}$, and $\mathrm{B}$ ) and $\mathrm{Cl} / \mathrm{Br}$ ratios (Chiaradia et al., 2006; Monteiro et al., 2008a; Xavier et al., 2008, 2012). However, the ca. 2.70-2.68 Ga IOCG mineralizing system $(2712 \pm 4.7 \mathrm{Ma}$; U-Pb LA-MC-ICPMS in monazite; $2710 \pm 11 \mathrm{Ma}$ and $2685 \pm 11 \mathrm{Ma}$; Re-Os in molybdenite; Moreto et al., 2015a, 2015b) does not overlap in time with the emplacement of ca. $2.74 \mathrm{Ga}$, post-orogenic $\mathrm{A}_{2}$-type granites, or coeval gabbros. A significant interval of up to $40 \mathrm{Ma}$ outweighs the duration of a magmatic-hydrothermal system related to the emplacement of granitic bodies.

Thus, the ca. 2.70-2.68 Ga IOCG events record possible inheritance of magmatic signatures through mechanisms of fluid-rock interaction involving reactive gabbro and/or feldspar-bearing felsic rocks, with special importance of the ca. 2.74 Ga bimodal magmatism, during the Carajás Basin inversion. However, coeval magmatism, not yet identified in the province, or a protracted magmatic history during the Neoarchean, cannot be ruled out.

The 2.57 Ga IOCG event $(2576 \pm 8 \mathrm{Ma}$; Re-Os molybdenite; Réquia et al., 2003; $2575 \pm 12 \mathrm{Ma}$; U-Pb SHRIMP monazite age; Tallarico et al., 2005) is only recorded in the northern portion of the Carajás Domain (e.g. Salobo and Igarapé Bahia). It is related to hightemperature hydrothermal alteration (magnetite-almandinegrunerite-biotite) strongly controlled by shear zone reactivation (e.g. Cinzento Shear Zone). This age coincides with that of ca. 2.57 Ga Old Salobo granite (Machado et al., 1991), pointing to the importance of granite genesis for the establishment of a magmatichydrothermal system. However, dating of sulfides (e.g., chalcopyrite and chalcocite) in these deposits by the $\mathrm{Pb}-\mathrm{Pb}$ method yielded older Neoarchean ages (2770 Ga to 2700 Ga; Tassinari et al., 2003; Galarza et al., 2008). Thus, overprinting processes at ca. $2.57 \mathrm{Ga}$, related to shear zone reactivation, may also be possible.

Paleoproterozoic IOCG deposits (e.g. Alvo 118; Sossego orebody at the Sossego $\mathrm{Cu}-\mathrm{Au}$ mine) have signatures typically associated with A-type granites (elevated $\mathrm{U}-\mathrm{Au}$ and $\mathrm{Nb}-\mathrm{Sn}-\mathrm{Y}-\mathrm{Bi}-\mathrm{Be}-\mathrm{HREE}-$ F contents), formed after the the ca. 2.4 Ga Great Oxidation Event as evidenced by the major contribution of surface-derived fluids with an oxidized sulfur (sulfate) source $\left(\delta^{34} \mathrm{~S}_{\mathrm{cpy}}>7.5 \%\right)$.

\subsection{Magmatic-hydrothermal gold and base metal systems in the Tapajós Mineral Province}

As epithermal mineralization and associated porphyry deposits are typically formed at very shallow crustal environments, their 
preservation in Precambrian terranes is hampered due to the weathering, erosion and subsequent metamorphic events. Epithermal deposits are typically preserved in Quaternary or Tertiary terranes, with few Cretaceous, Paleozoic and Neoproterozoic occurrences. However, many well-preserved and unmetamorphosed Paleoproterozoic occurrences of epithermal mineralization have been described in the last years in the Tapajós Mineral Province (Juliani et al., 2005) and Iriri and Xingu regions. These high-, intermediate- and low-sulfidation mineralizations are associated with 2.0 to $1.95 \mathrm{Ga}$ calc-alkaline volcanic rocks and $1.88-1.86 \mathrm{Ga}$ post-collisional high-K to A-type volcanic sequences and dikes, mainly towards the back-arc zone.

The expressive number of secondary gold mineralizations in alluvium and colluvium deposits largely spread in volcanic units, the absence of shear zones, low to medium-grade metamorphic terranes and of the orogenic (metamorphic-hydrothermal) fluids in the gold ores, indicate a significant geologic potential for the occurrence of gold and silver epithermal mineralization in the southern part of the Amazonian Craton, associated with both calcalkaline and alkaline volcanism. Seemingly, high-K post-collisional and A-type volcanic rocks affected by epithermal hydrothermal systems point to a potential for precious metal low-sulfidation mineralization (Juliani et al., 2005; Fernandes et al., 2011; Juliani et al., 2014; Echeverri-Misas, 2015; Tokashiki et al., 2015).

High-sulfidation precious metal mineralization (plus intermediate- and low-sulfidation produced by primary reduction of magmatic-derived fluids and by mixing with meteoric waters) is always associated with calc-alkaline magmatism. The well-known genetic relationship between epithermal high-sulfidation mineralization with $\mathrm{Cu}, \mathrm{Cu}-\mathrm{Au}$ and $\mathrm{Cu}-\mathrm{Mo} \pm \mathrm{Au}$ porphyry opens an interesting perspective for the occurrence of low-grade/large-ton deposits in the Amazonian Craton, especially in the Tapajós Mineral Province, associated with shallow emplaced granites and porphyries of the Parauari magmatic event (ca $1.89 \mathrm{Ga}$ ), as well as older unnamed rhyolite units, with ages ranging from 2.0 to $1.96 \mathrm{Ga}$. One example of this type of mineralization is represented by the $\mathrm{Au}-\mathrm{Cu}$ Palito porphyry-type and the $\mathrm{Cu}-\mathrm{Mo} \pm$ Au porphyry style in the Chapéu do Sol occurrence. In addition, the high-K late to postcollisional I-type subvolcanic granites, as well as the A-type porphyry stocks show potential for the generation of $\mathrm{Cu}-\mathrm{Au}$ and goldonly porphyries in the intra-arc and back-arc environment, where volcanic rocks host epithermal $\mathrm{Au}-\mathrm{Ag}$ mineralization.

The preliminary geological and geophysical data suggest at least two magmatic and metallogenetic events, resulting in a magmatic zoning associated with a continuous $\mathrm{W}-\mathrm{E}$ oriented subduction northward (today), generated in continental magmatic arcs, with less evolved rocks with Cu-porphyry potential in the southern part of the belt.

The ca. $1.88 \mathrm{Ga}$ andesites of the Sobreiro Formation (Iriri Group) in the Xingu area are considered to be products of a flat subduction event (Fernandes et al., 2011). NW-SE and NE-SW fault zones in TGP and Xingu areas, respectively, control the emplacement of Atype granite and of rhyolite dikes. These structures were also tectonically reactivated at ca. $1.8 \mathrm{Ga}$.

\subsection{Gold-Copper and base metal deposits of the Alta Floresta Gold Province}

The close spatial relationship with relatively oxidized (magnetite-bearing) A- and I-type granitic plutons emplaced into a volcanic arc setting (and subordinate within a post-collisional onset), the types and distribution of hydrothermal alteration, the ore mineral association, the fluid inclusions assemblages, and the isotopic signature suggest that gold deposits from AFGP were formed in magmatic-hydrothermal systems that developed at different crustal levels, including system portions distal from the magmatic source.

These disseminated and vein-type $\mathrm{Au} \pm \mathrm{Cu}$ deposits tend to form at deeper crustal levels, at pressures of $1 \mathrm{kbar}-3.6 \mathrm{kbar}$, whereas the $\mathrm{Au}+$ base metal deposits may have been emplaced at epizonal levels ( $\sim 0.7 \mathrm{kbar})$. The data also suggest a strong magmatic signature for the Au systems, whereas external fluids, essentially of meteoric origin, may have interacted with magmatic fluids in the vein-type $\mathrm{Au}+$ base metal ore systems. Therefore, the geological characteristics of the $\mathrm{Au} \pm \mathrm{Cu}$ systems are similar to those related to porphyry-style mineralization, but emplaced at deeper crustal levels, whereas the Au + base metal deposits show many similarities to low and intermediate-sulfidation epithermal systems.

The pyrite and molybdenite $\mathrm{Re}-\mathrm{Os}$ ages for the disseminated gold deposits and the sericite ${ }^{40} \mathrm{Ar}-{ }^{39} \mathrm{Ar}$ ages for the vein-type $\mathrm{Au}+$ base metals deposits are the first geochronological constraints on the timing of gold metallogeny in the province. These data overlap, within their respective uncertainties, the crystallization ages of the Juruena microgranite $(1792 \pm 5.8 \mathrm{Ma}), \mathrm{X} 1$ quartzfeldspar porphyry $(1773 \pm 5.7 \mathrm{Ma})$, and the União do Norte Porphyry (1775 $\pm 7.5 \mathrm{Ma}$; Francisco deposit). This reinforces the importance of porphyry-related magmatic-hydrothermal activity within the province (Fig. 8). This relationship could be also extended to the Pé Quente deposit, where subvolcanic syenite/ quartz syenite dikes with disseminated ore are often observed.

This proposition differs from that of previous works (Paes de Barros, 2007; Silva and Abram, 2008; Miguel-Jr., 2011) in the following aspects: (1) the $\mathrm{Re}-\mathrm{Os}$ and ${ }^{40} \mathrm{Ar}-{ }^{39} \mathrm{Ar}$ ages in the investigated deposits are substantially different from the ages of their felsic intrusive host rocks, except in the case of the crosscutting porphyry units; (2) gold metallogeny in the province may be actually restricted to a major single event and is not related to multiple events (e.g. $1.98-1.95 \mathrm{Ga}, 1.89-1.87 \mathrm{Ga}$, and ca. $1.77 \mathrm{Ga}$ ), as suggested by the crystallization ages of the plutonic host rocks; (3) I- and A-type subvolcanic and related volcanic rocks are probably the closest representatives of the causative magmatism that may have triggered, with the aid of regional structures, large-scale magmatic-hydrothermal systems and promoted gold mineralization; and (4) the emplacement of the quartz-feldspar porphyries would be better correlated to the Colíder (1.78-1.77 Ga) and Teles Pires suites $(1.78-1.75 \mathrm{Ga})$.

Collectively, these subvolcanic rocks are strongly oxidized (magnetite-bearing) and evolved, but those related to disseminated gold deposits are calc-akaline plutons emplaced into a volcanic arc setting (I-type), whereas those associated with $\mathrm{Au}+$ base metal deposits are a product of within-plate alkaline magmas (A-type; Assis et al., 2014; Assis, 2015).

\subsection{Metallogenesis in the Transamazonas Province}

Despite the importance of the Transamazonas Province for the evolution of the Amazonian Craton, few studies deal with mineral deposits related to magmatism. No clear genetic relationships have linked gold deposits to granitic magmatism in this province to date, yet some issues deserve further investigation: (1) the role of the Amapari Granite on gold mineralization (fluids, remobilization, heat source?) at the Amapari/Tucano deposit; (2) although available data indicate that the gold deposits of the Carecuru Domain are fairly typical orogenic gold deposits, a significant part of the oxygen, hydrogen and lead isotope compositions are consistent with felsic magmatism (Klein et al., 2009), and, very importantly, (3) the role of the widespread charnockite magmatism on orogenic gold mineralization. On the other hand, $\mathrm{Sn}-\mathrm{Nb}-\mathrm{Ta}$ mineralization in greisen and pegmatite, which are relatively common in the SEGuiana Shield (State of Amapá), are probably related to post- 
orogenic to anorogenic felsic magmatism of 1.84 to 1.75 Ma.

\subsection{Geological evolution of the Pitinga region: implications on the metallogenetic system}

The gap between the cauldron complex (Iricoumé Group with associated granitic bodies of the Mapuera Suite) and the Madeira Suite is approximately of $35 \mathrm{Ma}$, based on the ages of the Simão $(1875 \pm 4 \mathrm{Ma})$ and the Europa $(1839 \pm 10 \mathrm{Ma})$ granites. The granite bodies of the Madeira Suite occur in the area occupied by the volcanic sequences, with shapes similar to those of the Mapuera granitic bodies. Emplacement of Madeira plutons was controlled by reactivation of cauldron complex structures and pre-existing structures, such as the NE-SW corridor. Therefore, Bastos Neto et al. (2014) reanalyzed the geological evolution of the Pitinga region from an extensional environmental perspective, in which three successive episodes of A-type magmatism and basin formation (Urupi Formation) occurred. The first episode of A-type magmatism (Iricoumé Group and Mapuera Suite) resulted from mantle sources previously modified by subduction (Ferron et al., 2006, 2010). In the second episode, numerous distinctive magmas (Europa granite, Água Boa granite, and the early facies of the Madeira granite) formed from different mixtures of crustal and mantle sources (Lenharo, 1998). In the third episode, represented by the AEG, the richness in Sn indicates a much more substantial participation of crustal components in the melt generation. This interpretation has implications for the proposed models for the AEG. (1) The structural data disfavor the model linking the AEG to earlier facies of the Madeira granite (Costi, 2000, second model). (2) The ages obtained for the Europa granite do not permit linking the AEG origin to the Europa granite by fractional crystallization or other differentiation processes (Lenharo, 1998 model). (3) The geological evolution, characterized by three successive stages of Atype magmatism with successively shallower sources, does not corroborate the model that links the AEG with a mantle source (Costi, 2000, first model).

The model created by Martin (2006), which relates the A-type granites of crustal origin to the open-system fenitization-type reactions controlled by alkali- and silica-bearing mantle-derived fluid in an extensional environment, accommodates all of the features described above as long as a gradual rise of isotherms along the successive tectonic reactivations is taken into account (Bastos Neto et al., 2009). The generation of the AEG melt is related to the third step of the isotherm rise, when mantle fluid ascended further into the crust, promoted fenitization-type reactions in rocks previously enriched in Sn, and introduced elements, such as F, Nb, Y, REE, and Th in anomalous concentrations. It is also conceivable that these rocks were already fenitized in the previous stage and that the $\mathrm{F}$ intake, which made them fusible, occurred in the third stage.

The high F content in the melt played a key role in transport and distribution of $\mathrm{Sn}$ and $\mathrm{Nb}$ in the rock during the magmatic stage. $\mathrm{F}$ complexes transported these elements throughout the AEG, being responsible for the dispersed character of the cassiterite and pyrochlore mineralization. Zircon and xenotime crystallization was inhibited until the late magmatic stages of the AEG, resulting in a more heterogeneous distribution of these mineralizations, with enriched zones where pegmatitic AEG and/or miarolitic cavities are more abundant. The high $\mathrm{F}$ content in the magma was also responsible for xenotime crystallization with a very particular composition. Fluorine (up to 5.10\%) occurs in all xenotime crystals from core AEG. This halogen controls the ratio of REE/Y by controlling the lattice parameters $\underline{a}$ and $\underline{c}$ which are significantly shortened in F-rich xenotime. The richer the xenotime is in $\mathrm{F}$, the richer it is in HREE, notably by Er and $\mathrm{Yb}$. It is here interpreted that fluorine substitutes for $\mathrm{O}$ to form $\mathrm{PO}_{3} \mathrm{~F}$ tetrahedral (Bastos Neto et al., 2012).

The crystallization of magmatic cryolite since the earlier stages buffered the content of F in the melt (Bastos Neto et al., 2009; Dolejs and Baker, 2007). The extreme F-enrichment in residual melt supposed by Lenharo (1998) and Costi (2000), the first step of the MCD formation according to their models, is unlikely to have been attained. There is no evidence of silicate-fluoride liquid-liquid immiscibility (which formed the MCD, according to Lenharo's model). There is no evidence that the melt split into a high-water, relatively F-poor portion and a low-water, $\mathrm{Na}-\mathrm{Al}-\mathrm{F}$-rich residual portion (to form the MCD; Costi's model). Moreover, fluid inclusion data shows that the MCD formed from an aqueous fluid (salinity ranges from 1.7 to $22.4 \mathrm{wt} \%$ eq. $\mathrm{NaCl}$ ). The highest homogenization temperature $\left(400{ }^{\circ} \mathrm{C}\right)$ measured in massive cryolite determines the minimum starting temperature for the hydrothermal process; the $\mathrm{MCD}$ formation continued until $\sim 100{ }^{\circ} \mathrm{C}$. There is no evidence of a continuous transition from volatile-rich silicate melts to solute-rich fluids. The abrupt magmatic-hydrothermal transition triggered three processes: (1) a discrete albitization and crystallization of hydrothermal cryolite disseminated in the core AEG; (2) the pyrochlore columbitization; and (3) the MCD formation (Bastos Neto et al., 2009; Ronchi et al., 2011).

The new understanding of the geological evolution and of the AEG formation expands the prospecting potential of the Pitinga Province. Geothermal anomalies related to the magmatism of the Iricoumé Group and Mapuera granites have affected the Pitinga area for long time. The hydrothermal processes associated with these rocks may have been much more important than previously supposed. In this extensional environment, the crustal thinning was accompanied by an increasing participation of heat and fluids from the mantle. Then, two successive stages of granitic magmatism with distinguishing petrographic features and associated mineralization occurred: (1) the evolved leucogranites associated with the early facies of the Madeira granite and the Agua Boa granite (with Sn-greisens associated); (2) the AEG (i.e. the Madeira polymetallic deposit) became associated with the Madeira granite, which represents a particular case in the craton. For the latter, the main criteria for prospecting are the associations with NE-SW lineaments and the local control by brittle $\mathrm{N}-\mathrm{S}$ structures or by preexisting caldera structures, which are supposed to create evidence even for blind and relatively deep deposits. The F-rich hydrothermal process associated (MCD formation) is supposed to generate geochemical and mineralogical indices even of relatively deep deposits.

\subsection{The Rondônia Tin Province}

The rare-metal granites (tin dominant) of the RTP (Fig. 12) are interpreted as A-type granites related to late to post-collisional stages $(1.34-1.30 \mathrm{Ga})$, which succeeded the assembly of the Rondonian-San Ignacio crust $(1.50-1.30 \mathrm{Ga})$ and to the evolution of the Sunsás-Aguapeí tectonic provinces (1.20-0.95 Ga; Bettencourt et al., 1999; Bettencourt et al., 2010). The tin-granites are highly evolved A-type, P-poor reduced fluorine-rich peraluminous alkalifeldspar granite and contain topaz and/or muscovite or zinnwaldite. The porphyritic facies shows a "snowball texture", indicative of magmatic origin (Pollard, 1989b; Sun and Yu, 1992; Bettencourt et al., 2005). Their geochemical characteristics are comparable to the low $\mathrm{P}_{2} \mathrm{O}_{5}$ ( $0.10 \mathrm{wt} \%$ ) sub-type of topaz-bearing granites (Taylor, 1992; Taylor and Fallick, 1997).

Stockworks and veins occur in the Oriente Novo deposit and in contrast, the Santa Bárbara deposit is dominantly a preserved mineralized cupola with associated bed-like greisen bodies. These deposits contain a similar rare-metal suite that includes $\mathrm{Sn}( \pm \mathrm{W}, \mathrm{Ta}$, $\mathrm{Nb})$. 
Primary silicate-melt inclusions with a Na-rich aqueous-phase, with or without $\mathrm{CO}_{2}$ and salinity from 0.5 to $15 \mathrm{wt}$.\% $\mathrm{NaCl}$ eq. were identified only in the Santa Barbara deposit, and indicate a minimum crystallization temperature for the albite granite at $\mathrm{Tt} \geq 600^{\circ} \mathrm{C}$.

The early primary fluids related to mineralization in the Oriente Novo deposit show low to moderate salinity (0.4-13.8 wt. \% $\mathrm{NaCl}$ eq.), which homogenize at temperatures between 190 and $440{ }^{\circ} \mathrm{C}$. In the Santa Bárbara deposit, this early fluid is represented by low salinity (5-12 wt. \% $\mathrm{NaCl}$ eq.) and a low $\mathrm{CO}_{2}$-bearing aqueous fluid, which homogenize at a more restricted temperature range $\left(340-390^{\circ} \mathrm{C}\right)$. In the Santa Bárbara and Oriente Novo deposits, this type of fluid may account for the deposition of early-disseminated cassiterite and columbite-tantalite, either directly from a melt or from a coexisting vapor, as well as from a late-magmatic fluid (see: Haapala, 1997; Linnen, 1998). The compositional range and homogenization behavior are consistent with immiscibility around $350-370{ }^{\circ} \mathrm{C}$ and $350-450{ }^{\circ} \mathrm{C}$, respectively. This process is responsible for the successive precipitation of cassiterite, wolframite and minor columbite-tantalite, down to the temperature of $\sim 250{ }^{\circ} \mathrm{C}$. These oxides continued to grow up to the post-magmatic stage in the presence of a magmatic-derived fluid mixed with external fluids.

The second type of fluid inclusions, also related to deposition of cassiterite, wolframite and minor columbite-tantalite in the Oriente Novo deposit (Th $>240{ }^{\circ} \mathrm{C}$ ), is represented by aqueous solutions with minor $\mathrm{CO}_{2}$ and low to moderate salinities (2.4-14.1 wt. \% $\mathrm{NaCl}$ eq.), which homogenize between 100 and $340{ }^{\circ} \mathrm{C}$. In the Santa Bárbara deposit, these fluids are represented by aqueous fluid inclusions in quartz-cassiterite veins, which have low salinities (0.3-3.0 wt. \% $\mathrm{NaCl}$ eq.) and homogenize at $320-380{ }^{\circ} \mathrm{C}$.

The trapping $\mathrm{P}-\mathrm{T}$ conditions $\left(\mathrm{P}_{\mathrm{t}}, \mathrm{T}_{\mathrm{t}}\right)$ of the observed early fluids in Oriente Novo deposits, suggest hydrothermal activity at 240-440 ${ }^{\circ} \mathrm{C}$ and $1.0-2.6 \mathrm{kbar}$, close to lithostatic. The observed progressive decrease in $T_{t}$ and $P_{t}$ indicate either erosion of overlying rock or an open hydrostatic system and hydraulic fracturing of the host-rocks. The contrasting fact is that in the Santa Bárbara deposit, the early magmatic and late-magmatic fluids indicate $T_{t}$ from 350 to $400{ }^{\circ} \mathrm{C}$ and a $P_{t}$ from 300 to 200 bar, near hydrostatic. The depth of emplacement at the Oriente Novo deposit is roughly $9.8 \mathrm{~km}$ and is compatible with a transitional hypabyssal to plutonic environment. The Santa Bárbara deposit is shallower (maximum $=1.8 \mathrm{~km}$ ), characteristic of subvolcanic environment. These fluids affected the magmatic-stage rocks and modified the primary fluid inclusions of quartz from granites, attesting some hydro-fracturing and mineral equilibrium at the post-magmatic stage.

Later-stage post-magmatic aqueous fluids, in the Santa Bárbara deposit, show a much larger range of homogenization temperatures $\left(94-380^{\circ} \mathrm{C}\right)$, than in the other study deposits, lower salinity ( $0-3$ wt. \% $\mathrm{NaCl}$ eq.) and include late-barren-quartz, muscovite, and kaolinite veins. The low temperature $\left(120-90^{\circ} \mathrm{C}\right)$ late-fluid type is also high-saline and Ca-rich and was associated with meteoric hydrothermal water that percolated along fissures (open system) at shallow depths. At Santa Bárbara, three processes are responsible for cassiterite genesis: 1) immiscibility in conditions of high ratio of rock/fluid interaction in lens-shaped greisen bodies and greisen stockwork, 2) boiling of sodic aqueous fluids in cassiterite-quartz veins, and 3) mixing of saline magmatic fluids with high proportions of cold low-salinity meteoric fluids, in muscovite veins.

In all cases, the post-magmatic late-fluids resulted from decreasing temperature as mixing and dilution proceeded below $290{ }^{\circ} \mathrm{C}$. The switch over of the process would lead to the predominance of an essentially aqueous solution $\left(\mathrm{H}_{2} \mathrm{O}-\mathrm{NaCl} \pm \mathrm{KCl}\right.$ system $)$. These fluids may represent a mixture of magmatic derived fluids and hydrothermal meteoric water (dominant) components, or different overprints on granites of diverse chemical composition.

The oxygen and hydrogen stable isotope data indicate that the fluids contained a magmatic component mixed with meteoric water. Hydrofracturing, immiscibility, greisenization and loss of $\mathrm{CO}_{2}\left( \pm \mathrm{CH}_{4}\right)$ with falling temperature, are the principal processes responsible for $\mathrm{Sn}-\mathrm{W}$ and associated rare-metal deposition. In the Santa Bárbara deposit, oxygen-isotope geothermometry indicates temperatures of $500{ }^{\circ} \mathrm{C}$ for the bed-like greisen bodies and $400^{\circ} \mathrm{C}$ for the cassiteritequartz veins. The calculated isotopic composition of water in equilibrium with host metasomatites $\left(\delta^{18} \mathrm{O}_{\mathrm{H}_{2} \mathrm{O}}=1.1-9.8 \%\right.$ ) is consistent with a magmatic origin but with a variable hydrothermal-meteoric component for the fluids, except for muscovite $\left(\delta^{18} \mathrm{O}_{\mathrm{H}_{2} \mathrm{O}}=-6.4 \%\right.$ ) and late-quartz $\left(\delta^{18} \mathrm{O}_{\mathrm{H}_{2} \mathrm{O}}=-3.8 \%\right.$ ) veins, which show a dominant meteoric water component.

A contrasting $\delta^{18} \mathrm{O} / \delta \mathrm{D}$ behavior is also observed in the Santa Bárbara deposit: the $\delta \mathrm{D}$ values for micas from coarse-greisen indicate a narrow range of variations for a wide range of $\delta^{18} \mathrm{O}$ values, as well as deuterium enrichment in the fluids. This may reflect re-equilibration of aqueous fluid with granite at low waterrock ratios and progressively lower temperatures, as proposed by Smith et al. (1996) for similar vein fluids from the Cligga Head Sn-W deposit (SW England).

The Bom Futuro deposit differs from the above mentioned two deposits by presenting two phases of tin mineralization related to: 1 - older zoned pegmatite and quartz veins containing cassiterite, stannite and base metal sulfides; and 2 - pipe- like greisen bodies with F-cassiterite, wolframite, pyrite and base metal sulfides. Fluid inclusions and oxygen isotope studies in cassiterite and quartz from older pegmatites and veins (Souza, 2003) indicate a minimum temperature of $400{ }^{\circ} \mathrm{C}$ for the mineralization and cassiterite and quartz from zoned greisen bodies show a similar minimum temperature of $400^{\circ} \mathrm{C}$.

Historic exploration has been directed to placer and soft shallow primary deposits, and drilling for primary ore was performed during the 1980's and over the last ten years, at the São Lourenço and Bom Futuro tin fields. Avenue Resources Limited, Australia, commenced at São Lourenço, a 2000 drill program during 2012 and results have confirmed high-grade tin mineralization in one drill hole. Metalmig and White Solder have launched modest exploration projects. White Solder is conducting exploration programs in several prospects. The Rondônia Tin Province is underexplored, but there are still areas of favorable ground and potential for further reserves (primary and alluvial) to be established, associated with the SLCIS, SCIS and YGRIS. However, present and future exploration should be directed towards the discovery of paleovalleys and deeper primary mineralization.

\section{Conclusions}

The Amazonian Craton hosts world-class metallogenic provinces with a wide range of styles of primary precious, rare, base metal deposits, which are spatially and/or temporally related to granitoids. However, the mineral potential in vast areas of the AC is still to be unraveled.

In the Carajás Mineral Province, multiple hydrothermal IOCG events in the Carajás Domain were identified. Coupled lithochemical and isotopic data of the IOCG, $\mathrm{Au}-\mathrm{Cu}$, and polymetallic deposits (Cu-Au-W-Bi-Mo-Sn and $\mathrm{Cu}-\mathrm{Au}-\mathrm{Li}-\mathrm{Be}-\mathrm{Sn}-\mathrm{W})$ allow identification of: (i) great diversity of hybrid Archean IOCG deposits as a function of fluid-rock interaction involving maficultramafic units and granitoids, along important structural corridors; (ii) overlapping of Archean (ca. $2.74 \mathrm{Ga}$ and ca. $2.57 \mathrm{Ga}$ ) and Paleoproterozoic (ca. $1.88 \mathrm{Ga}$ ) processes possibly due to tectonic 
reactivations; and (iii) installation of new hydrothermal systems controlled by Paleoproterozoic A-type magmatism and extensional tectonic evolution.

In addition, the metallogenetic diversity of the Paleoproterozoic mineral deposits at Carajás, including W, Sn, Au-EGP, Fe-Cu-Au(ETR), $\mathrm{Cu}-\mathrm{Au}-(\mathrm{Mo}-\mathrm{W}-\mathrm{Bi}-\mathrm{Sn})$ and $\mathrm{Cu}-\mathrm{Au}-(\mathrm{Li}-\mathrm{Be}-\mathrm{Sn}-\mathrm{W})$ reflect: (a) the geochemical affinity and magma oxidation state related to ca. $1.88 \mathrm{Ga} \mathrm{A}_{2}$-type granites and quartz porphyries; (b) large-scale circulation of externally-derived fluids promoted by widespread granite emplacement and (c) inheritance of Archean signatures and components, notably $\mathrm{Cu}, \mathrm{Ni}, \mathrm{Co}$, and $\mathrm{Pd}$.

The Transamazonas Province (2.26-1.95 Ga) hosts pre-, syn-, and post-orogenic to anorogenic granitic magmatism related to a protracted tectonic evolution. However, mineralization associated with magmatic events is still unclear, except greisen and pegmatite $\mathrm{Sn}-\mathrm{Nb}-\mathrm{Ta}$ deposits, which are related to 1.84 to $1.75 \mathrm{Ga}$ lateorogenic to anorogenic A-type granites. The role of granite/charnockite emplacement and related magmatic fluids in the orogenic gold mineral systems remains uncertain.

In the Tapajós and Alta Floresta gold provinces, the recognition of magmatic-hydrothermal systems and associated $\mathrm{Cu}-\mathrm{Au}$ and $\mathrm{Cu}-\mathrm{Mo} \pm \mathrm{Au}$ porphyry-type and high-, intermediate- and low sulfidation Au-(base metal) mineralization, has expanded the metallogenetic potential of these increasingly important provinces. In the Tapajós Gold Province, high-, intermediate- and lowsulfidation mineralization is associated with 2.0 to 1.95 Ga calcalkaline volcanic rocks and $1.88-1.86$ Ga post-collisional high-K to A-type volcanic sequences and dikes, mainly towards the backarc zone. These deposits might be related to at least two magmatic and metallogenetic events associated with a continuous W-E oriented northward subduction, generating continental magmatic arcs, with less evolved rocks with $\mathrm{Cu}$-porphyry potential in the southern part of the belt.

In the Alta Floresta Gold Province, disseminated and vein-type $\mathrm{Au} \pm \mathrm{Cu}$ deposits, similar to porphyry-type mineralization, and the $\mathrm{Au}+$ base metal deposits, with intermediate- and low sulfidation epithermal characteristics, are genetically related to relatively oxidized (magnetite-bearing) A- and I-type porphyries. The latter were emplaced within a post-collisional onset, crosscutting the ca. $1.98 \mathrm{Ga}$ to $1.87 \mathrm{Ga}$ host granites. The age of the porphyries overlap the $\mathrm{Re}-\mathrm{Os}$ and ${ }^{40} \mathrm{Ar}-{ }^{39} \mathrm{Ar}$ ages obtained for the mineralized stages. These suggest a single and major gold event in the Alta Floresta Gold Province from 1.78 Ga to 1.77 Ga.

Brazil has been one of the most important world producers of tin, with an approximate total output of $\sim 600,000 \mathrm{t} / \mathrm{Sn}$ for both Rondônia and Pitinga provinces. The Pitinga Tin Province includes the Madeira $\mathrm{Sn}-\mathrm{Nb}-\mathrm{Ta}-\mathrm{F}$ deposit, Sn-greisens, and Snepisyenites. These are associated with A-type granites of the Madeira Suite (1.84-1.82 Ga), which evolved from a postcollisional extensional, towards a within-plate setting. The Rondônia Tin Province hosts rare-metal (Ta, Nb, Be, Zr, REE + Y) and $\mathrm{Sn}-(\mathrm{W})$ mineralization, which is associated with the São Lourenço-Caripunas (1.31-1.30 Ga), related to the post-collisional stage of the Rondônia San Ignácio Province (1.56-1.30 Ga) and to the Santa Clara (1.08-1.07 Ga) and Younger Granites of Rondônia (0.99-0.97 Ga) A-type granites. The latter are linked to the evolution of the Sunsás-Aguapeí Province (1.20-0.95 Ga). One of the most important contrasting feature of both tin provinces is: in Rondônia the tin mineralization is associated with tinbearing rapakivi peraluminous granites with high Sn and W, and subordinate concentrations of $\mathrm{Nb}$, Ta and $\mathrm{Y}$, whereas at Pitinga the main tin mineralization is related to an albite granite (Madeira world-class deposit), a peralkaline cassiterite-cryolite-riebeckite-bearing subsolvus granite suite. This explains the contrasting mineral assemblages.

\section{Acknowledgments}

We would like to thank VALE S.A. for providing logistical support. This research has been supported by the Fundação de Amparo à Pesquisa do Estado de São Paulo - FAPESP (Proc. N ${ }^{0}$. 2009/183710; 2013/25659-5), CNPq (308365/2014-3, 481969/2013-6, 472549/ 2009-0, 405839/2013-8), CNPq-CT-Mineral 550342/2011-7, Instituto Nacional de Ciência e Tecnologia Geociências da Amazônia INCT GEOCIAM (Grant MCT/CNPq/FAPESPA/PETROBRAS 573733/ 2008-2), Convênio VALE/Fapespa ICAAF 053/2011 (Prof. Dr. Davis Carvalho). We are also grateful to Roberto Dall'Agnol and Reimar Seltmann for their constructive reviews and to Valdecir de Assis Janasi's editorial comments that have greatly improved the manuscript.

\section{References}

Almeida, F.F.M., Hasui, Y., Brito Neves, B.B., Fuck, R.A., 1981. Brazilian structural provinces: an introduction. Earth-Sci. Rev. 17, 1-29.

Almeida, M.E., Fraga, L.M.B., Macambira, M.J.B., 1997. New geochronological data of calc-alkaline granitoids of Roraima State, Brazil. In: South-American Symposium on Isotope Geology, Campos do Jordão, São Paulo (CD-ROM).

Almeida, J.A.C., Dall'Agnol, R., Oliveira, M.A., Macambira, M.J.B., Pimentel, M.M., Rämö, O.T., Guimarães, F.V., Leite, A.A.S., 2011. Zircon geochronology and geochemistry of the TTG suites of the Rio Maria granite-greenstone terrane: implications for the growth of the Archean crust of Carajás Province, Brazil. Precamb Res. 120, 235-257.

Almeida, J.A.C., Dall'agnol, R., Leite, A.A.S, 2013, Geochemistry and zircon geochronology of the Archean granite suites of the Rio Maria granitegreenstone terrane, Carajás Province, Brazil. J. South Am. Earth Sci. 42, 103-126.

Amaral, G., 1974. Geologia Pré-Cambriana da Região Amazônica. Tese de Livre Docência, Instituto Geociências, Universidade de São Paulo, 212 p.

Aquino, L.B.M., Santos, M.D., Lafon, J.M., 2012. Geologia e Geocronologia do Granito Palito, Rocha Hospedeira do Depósito Aurífero do Palito. In: SBG, Congresso Brasileiro de Geologia, 46. Santos - SP, Anais.

Araujo Neto, H., Moreira, H.L., 1976. Projeto Estanho de Abonari. Relatório Final, DNPM/CPRM, Manaus, 2 v.

Assis, R.R., 2008. Contexto geológico e associação paragenética das mineralizações auríferas de União do Norte, região de Peixoto de Azevedo, Província de Alta Floresta (MT). Instituto de Geociências, Universidade Estadual de Campinas, Trabalho de Conclusão de Curso, 81 p.

Assis, R.R., 2011. Depósitos auríferos associados ao magmatismo granítico do setor leste da Província de Alta Floresta (MT), Craton Amazônico: tipologia das mineralizações, modelos genéticos e implicações prospectivas (Master thesis). Universidade Estadual de Campinas, Campinas, Brasil, 428 p.

Assis, R.R., 2015. Depósitos auríferos associados ao magmatismo félsico da Província de Alta Floresta (MT), Cráton Amazônico: litogeoquímica, idade das mineralizações e fonte dos fluidos (Doctorate thesis). Instituto de Geociências, Universidade Estadual de Campinas, Campinas, 363 p.

Assis, R.R., Xavier, R.P., Paes de Barros, A.J., Barbuena, D., Trevisan, V.G., Ramos, G.S., Teixeira, R.V., Miguel-Jr, E., Rodrigues, R.M., Stabile-JR, A., Santos, T.J.S. Miranda, G.M.T., Barros, M.A.S.A., Pinho, F., 2014. Depósitos de Au e Au + metais de base associados a sistemas graníticos paleoproterozóicos do setor leste da Província de Alta Floresta (MT), Cráton Amazônico. In: Silva, M.G., Neto, M.B.R., Jost, H., Kuyumjian, R.M. (Eds.), Metalogenia das Províncias Tectônicas Brasileiras. CPRM, Belo Horizonte, pp. 305-340.

Barbosa, J.P.O., Chaves, C.L., Costa Neto, M.C., Anjos, G.C., Rosa-Costa, L.T., 2013. Programa Geologia do Brasil-PGB. Macapá. Folha NA.22-Y-D. In: Estado do Amapá. Carta Geológica. Belém: CPRM, Escala 1:250.000

Barros, C.E.M., Sardinha, A.S., Barbosa, J.P.O., Macambira, M.J.B., 2009. Structure, petrology, geochemistry and zircon $\mathrm{U} / \mathrm{Pb}$ and $\mathrm{Pb} / \mathrm{Pb}$ geochronology of the synkinematic Archean (2.7 Ga) A-type granites from the Carajás Metallogenic Province, northern Brazil. Can. Mineral. 47 (6), 1423-1440.

Barros, M.A.S., Pimentel, M.M., Rocha, M.L.B.P., Silva, F.R., Padilha, R.A., Dantas, E.L., Moura, E., 2011. A Suíte Intrusiva Rio Dourado - um granito Tipo A de 1,88 Ga sudeste do Craton Amazônico - Mato Grosso - Brasil. Geol. USP Série Científica 11 (1), 75-93.

Bastos Neto, A.C., Pereira, V.P., Lima, E.F., Ferron, J.M.T.M., Minuzzi, O.R.R., Prado, M., Ronchi, L.H., Frantz, J.C., Botelho, N.F., 2005. O depósito de criolita da mina Pitinga (Amazonas). In: Marini, J.O., Queiroz, E., Ramos, B.W. (Eds.), Caracterização de Depósitos Minerais em Distritos Mineiros da Amazônia. DNPM/CTMINERAL/ADIMB, Brasília, pp. 477-552.

Bastos Neto, A.C., Pereira, V., Ronchi, L.H., Lima, E.F., Frantz, J.C., 2009. The Sn, Nb, Ta, F (Y, REE, Li) world-class deposit and the massive cryolite deposit associated with the albite-enriched facies of the Madeira A-type granite, Pitinga mining district, Amazonas State, Brazil. Can. Mineral. 47, 1328-1358.

Bastos Neto, A.C., Pereira, V., Pires, A.C., Barbanson, L., Chauvet, A., 2012. F-rich xenotime from the Nb-Ta-Sn Madeira world-class deposit associated with the albite-enriched granite at Pitinga (Amazonian, Brazil). Can. Mineral. 50, 1453-1466. 
Bastos Neto, A.C., Ferron, J.T.M.M., Chauvet, A., Chemale, F., Lima, E.F., Barbanson, L., Costa, C.F.M., 2014. U-Pb dating of the Madeira Suite and structural control of the albite-enriched granite at Pitinga (Amazonia, Brazil): evolution of the Atype magmatism and implications for the genesis of the Madeira Sn-Ta-Nb (REE, cryolite) world-class deposit. Precambrian Res. 243, 181-196.

Bettencourt, J.S., Nogueira, S., 2008. The Salamangone Au deposit. In: International Geological Congress, vol. 33. Oslo. https://abstracts.congrex.com (accessed 20.11.09.).

Bettencourt, J.S., Tosdal, R.M., Leite Júnior, W.B., Payolla, B.L., 1999. Mesoproterozoic rapakivi granites of the Rondônia Tin Province, southwestern border of the Amazonian craton, Brazil -I. Reconnaissance U-Pb geochronology and regional implications. Precambrian Res. 95, 41-67.

Bettencourt, J.S., Leite Júnior, W.B., Goraieb, C.L., Sparrenberger, I., Bello, R.M.S., Payolla, B.L., 2005. Sn-polymetallic greisen-type deposits associated with latestage rapakivi granites, Brazil: fluid inclusion and stable isotope characteristics. Lithos 80, 363-386.

Bettencourt, J.S., Leite Júnior, W.B., Ruiz, A.S., Matos, R., Payolla, B.L., Tosdal, R.M., 2010. The Rondonian-San Ignacio Provincein the SW Amazonian craton: an overview. J. South Am. Earth Sci. 2, 28-46.

Borges, R.M.K., Dall'Agnol, R., Costi, H.T., 2003. Geologia, petrografia e química mineral das micas dos greisens estaníferos associados ao pluton Água Boa, Pitinga (AM). Rev. Bras. Geociências 33, 51-62.

Borges, R.M.K., Villas, R.N.N., Fuzikawa, K., Dall'Agnol, R., Pimenta, M.A., 2009. Phase separation, fluid mixing, and origin of the greisens and potassicepisyenite associated with the Água Boa pluton, Pitinga tin province, Amazonian Craton, Brazil. J. South Am. Earth Sci. 27, 161-183.

Borges, R.M.K., Dreher, A.M., Almeida, M.A., Costi, H.T., Reis, N.J., Andrade, J.B.F., 2014. Metalogênese da Província Tapajós-Parima: Domínios Parima, Uaimiri e K'Mudku. In: Silva, M.G., Rocha Neto, M.B., Jost, H., Kuyumjian, R.M. (Eds.), Metalogênese das Províncias Tectônicas Brasileiras. CPRM, Belo Horizonte, pp. 215-228.

Botelho, N.F., Moura, M.A., Teixeira, L.M., Olivo, G.R., Cunha, L.M., Santana, M.U., 2005. Caracterização Geológica e Metalogenética do Depósito de Cu (Au, W, Mo, e Sn) Breves, Carajás. In: Marini, O.J., Queiroz, E.T., Ramos, B.W. (Eds.), Caracterização de Depósitos Minerais em Distritos Mineiros da Amazônia, pp. 339-389. DNPM-CT-Mineral-FINEP-ADIMB.

Chiaradia, M., Banks, D., Cliff, R., Marschik, R., de Haller, A., 2006. Origin of fluids in iron oxide-copper-gold deposits: constraints from $\delta^{37} \mathrm{Cl},{ }^{87} \mathrm{Sr} /{ }^{86} \mathrm{Sr}$ and $\mathrm{Cl} / \mathrm{Br}$. Miner. Deposita 41, 565-573.

Corbett, G.J., 2008. Influence of magmatic arc geothermal systems on porphyryepithermal Au-Cu-Ag exploration models. In: XLVIII Terry Leach Symposium, Australian Institute of Geoscientists, Bulletin, pp. 25-43.

Cordani, U.G., Assinari, C.C.G., Teixeira, W., Basei, M.A.S., Kawashita, K., 1979. Evolução Tectônica da Amazônia com base nos dados geocronológicos: Actas, II Congresso Geológico Chileno, pp. 137-148.

Cordani, U.G., Teixeira, W., 2007. Proterozoic accretionary belts in the Amazonian Craton. In: Hatcher Jr., R.D., Carlson, M.P., McBride, J.H., Martinez Catalan, J.R. (Eds.), 4-D Framework of Continental Crust, Geological Society of America Memoir, vol. 200, pp. 297-320. http://dx.doi.org/10.1130/2007.1200(14).

Cordeiro, A.A.C., Alves, C.A., Biagini, D.O., Fonseca, L.R., de Nascimento, J.A.S., Azevedo, L.L., Santos, F.F., 1988. Depósito de wolframita de Pedra Preta, sul do Pará. In: Cong. Bras. Geol., 35, Belém, 1988. Província Mineral de Carajás: Litoestratigrafia e principais depósitos minerais. Anexo aos anais, CVRD/SBG, pp. 161-165.

Corrêa, L.W.C., Macambria, M.J.B., 2014. Evolução da região de Santana do Araguaia (PA) com base na geologia e geocronologia Pb-Pb em zircão de granitoides. Rev. Inst. Geociências - USP 14, 45-66.

Costi, H.T., 2000. Petrology of Rare-metals-, High-F-alkaline Granites: the Example of the Albite Granite from the Pitinga Mine, Amazonas State, Brazil (Doctoral thesis). Federal University of Pará, Belém, Brazil, 345 pp.

Costi, H.T., Dall'Agnol, R., Moura, C.A.V., 2000. Geology and Pb-Pb geochronology of Paleoproterozoic volcanic and granitic rocks of Pitinga Province, Amazonian Craton, Northern Brazil. Int. Geol. Rev. 42, 832-849.

Costi, H.T., Dall'Agnol, R., Pichavant, M., Rämo, O.T., 2009. The peralkaline tinmineralized Madeira cryolite albite-rich granite of Pitinga, Amazonian Craton, Brazil: petrography, mineralogy and crystallization processes. Can. Mineral. 47, 1301-1327.

CPRM, 2006. Programa Integração, Atualização e Difusão de Dados da Geologia do Brasil: Subprograma Mapas Geológicos Estaduais. In: Reis, N.J., Almeida, M.E. Ferreira, A.L., Riker, S.L. (Eds.), Geologia e Recursos Minerais do Estado do Amazonas. CPRM/CIAMA, Manaus. Esc. 1:1.000.000. Texto Explicativo, 144 p.

Dall'Agnol, R., Oliveira, M.A., Almeida, J.A.C., Althoff, F.J., Leite, A.A.S., Oliveira, D.C. Barros, C.E.M., 2006. Archean and paleoproterozoic granitoids of the Carajás Metallogenic Province, eastern Amazonian craton. In: Symposium on Magmatism, Crustal Evolution and Metallogenesis of the Amazoniam Craton, Belém, Excursion Guide, pp. 99-150.

Dall'Agnol, R., Oliveira, D.C., 2007. Oxidized, magnetite-series, rapakivi-type granites of Carajás, Brazil: implications for classification and petrogenesis of A-type granites. Lithos 93, 215-233.

Dall'Agnol, R., Ramo, O.T., Magalhães, M.S., Macambira, M.J.B., 1999. Petrology of the anorogenic, oxidised Jamon and Musa granites, Amazonian craton: implications for the genesis of Proterozoic A-type granites. Lithos 46, 431-462.

Dall'Agnol, R., Teixeira, N.P., Ramo, O.T., Moura, C.A.V., Macambira, M.J.B., Oliveira, D.C., 2005. Petrogenesis of the Paleoproterozoic rapakivi A-type granites of the Archean Caraja's metallogenic province, Brazil. Lithos 80,
$101-129$.

Daoud, W.E.K., Antonietto Jr., A., 1985. Geologia do granito Água Boa, Pitinga, Amazonas. In: Simpósio de Geologia da Amazônia, 2, Belém, 1985, Anais, 3 pp. 17-33.

Dardenne, M.A., Schobbenhaus, C., 2001. O escudo do Brasil Central. In: Metalogênese do Brasil. Univ. Brasília/CPRM, Brasília, pp. 46-105.

Delinardo da Silva, M.A., 2014. Metatexitos e diatexitos do Complexo Xingu na região de Canaã dos Carajás: implicações para a evolução mesoarqueana do Domínio Carajás (Master thesis). Geoscience Institute, University of Campinas UNICAMP.

Dias, C.A.T., Leite Junior, W.B., Muzzolon, R., Bettencourt, J.S., 2013. Geologia do Pegmatito Estanífero Cascavel, Mina Bom Futuro, Rondônia. Geociências 32 (4) $731-745$.

DOCEGEO, 1988. Revisão litoestratigráfica da Província Mineral de Carajás Litoestratigrafia e principais depósitos minerais. In: 35th Congresso Brasileiro de Geologia, Belém. (Proceedings).

Dolejs, D., Baker, D.R., 2007. Liquidus equilibria in the system $\mathrm{K}_{2} \mathrm{O}-\mathrm{Na}_{2} \mathrm{O}-\mathrm{Al}_{2} \mathrm{O}_{3}-\mathrm{SiO}_{2}-$ $\mathrm{F}_{2} \mathrm{O}_{-1}-\mathrm{H}_{2} \mathrm{O}$ to $100 \mathrm{MPa}$ : II. Differentiation paths of fluorosilicic magmas in hydrous systems. J. Petrol. 48, 807-828.

Echeverri-Misas, C.M., 2010. Evolução magmática, alteração hidrotermal e gênese da mineralização de ouro e cobre do Palito, Província Aurífera do Tapajós (PA) (Master thesis). Instituto de Geociências, USP.

Echeverri-Misas, C.M., 2015. Geologia e alteração hidrotermal nas rochas vulcânicas e plutônicas paleoproterozoicas na porção sul da Província Mineral do Tapajós (PA) (Doctorate thesis). Instituto de Geociências, USP, 190 p, anexos.

Faraco, M.L.T., Marinho, P.A.C., Maia, R.G.N., Costi, H.T., 2009. Caracterização petrográfica e isotópica ( $\mathrm{Pb}-\mathrm{Pb}$ e $\mathrm{Sm}-\mathrm{Nd})$ de granitoides do Domínio Norte do Amapá. Região SE do Escudo das Guianas. In: Rizzotto, G., Quadros, M.L.E.S. Vasquez, M.L. (Eds.), Contribuições à Geologia da Amazônia, vol. 6, pp. 53-66.

Feio, G.R.L., Dall'Agnol, R., Dantas, E.L., Macambira, M.J.B., Gomes, A.C.B. Sardinha, A.S., Oliveira, D.C., Santos, R.D., Santos, P.A., 2012. Geochemistry, geochronology, and origin of the Neoarchean Planalto Granite suite, Carajás Amazonian craton: a-type or hydrated charnockitic granites? Lithos 151, 57-73.

Feio, G.R.L. Dall'Agnol, R. Dantas, E.L., Macambira, M.J.B., Santos, J.O.S., Althoff, FJ. Soares, J.E.B., 2013. Archean granitoid magmatism in the Canaã dos Carajás area: implications for crustal evolution of the Carajás province, Amazonian craton, Brazil. Precambrian Res. 227, 157-185.

Fernandes, C.M.D., Juliani, C., Monteiro, L.V.S., Lagler, B., Echeverri-Misas, C.M., 2011 High-K calc-alkaline to A-type fissure-controlled volcano-plutonism of the São Félix do Xingu region, Amazonian craton, Brazil: exclusively crustal sources or only mixed Nd model ages? J. South Am. Earth Sci. 32, 351-368.

Ferron, J.M.T.M., Bastos Neto, A.C., Rolim, S.B.A., Hoff, R., Umann, L.V., Minuzzi, O.R.R., 2002. Reconhecimento de uma mega-estrutura no distrito mineiro de Pitinga-AM: dados preliminares a partir da aplicação de técnicas de processamento digital de imagens ETM+ Landsat 7. II Simpósio de Vulcanismo, Belém-PA.

Ferron, J.M.T.M., Bastos Neto, A.C., Lima, E.F., Costi, H.T., Moura, C., Prado, M. Galarza, M. 2006. Geologia e geocronologia $\mathrm{Pb}-\mathrm{Pb}$ de rochas graníticas e vulcânicas ácidas a intermediárias Paleoproterozóicas da Província Pitinga, Craton Amazônico. Rev. Bras. Geociências 36 (3), 499-512.

Ferron, J.M.T.M., Bastos Neto, A.C., Lima, E.F., Nardi, L.V.S., Costi, H.T., Pierosan, R., Prado, M., 2010. Petrology, geochemistry, and geochronology of Paleoproterozoic volcanic and granitic rocks (1.89 to $1.88 \mathrm{Ga}$ ) of the Pitinga province, Amazonian Craton, Brazil. J. South Am. Earth Sci. 29, 483-497.

Galarza, M.A., Lafon, J.M., Macambira, M.J.B., 2006. Idades Pb-Pb das mineralizações auríferas dos depósitos Amapari (Amapá), Igarapé Bahia (Carajás) e Mamão (Rio Maria), Amazônia oriental. In: Simpósio de Geologia da Amazônia, 9, Resumos (CD-ROM)

Galarza, M.A., Macambira, M.J.B., Villas, R.N., 2008. Dating and isotopic characteristics $(\mathrm{Pb}$ and $\mathrm{S}$ ) of the $\mathrm{Fe}$ oxide-Cu-Au-U-REE Igarapé Bahia ore deposit, Carajás mineral province, Pará state, Brazil. J. South Am. Earth Sci. 25, 377-397.

Goldfarb, R., Groves, D.I., Gardoll, S., 2001. Orogenic gold and geologic time: a global synthesis. Ore Geol. Rev. 18, 1-75.

Grainger, C.J., Groves, D.I., Tallarico, F.H.B., Fletcher, I.R., 2008. Metallogenesis of the Carajás Mineral Province, Southern Amazon Craton, Brazil: varying styles of Archean through Paleoproterozoic to Neoproterozoic base- and precious-metal mineralisation. Ore Geol. Rev. 33, 451-489.

Groves, D.I., Goldfarb, R.J., Gebre-Mariam, M., Hagemann, S.G., Robert, F., 1998. Orogenic gold deposits: a proposed classification in the context of their crustal distribution and relationship to other gold deposit types. Ore Geol. Rev. 13, 7-27. http://dx.doi.org/10.1016/S0169-1368(97)00012-7.

Groves, D.I., Bierlein, F.P., Meinert, L.D., Hitzman, M.W., 2010. Iron oxide copper-gold (IOCG) deposits through Earth history: implications for origin, lithospheric setting, and distinction from other epigenetic iron oxide deposits. Econ. Geol. 105, 641-654.

Haapala, I., 1997. Magmatic and postmagmatic processes in tin-mineralized granites: topaz-bearing leucogranite in the Eurajöki rapakivi granite stock, Finland. J. Petrol. 38 (12), 1645-1659.

Hayward, N., Skirrow, R.G., 2010. Geodynamic setting and controls on iron oxide Cu$\mathrm{Au}( \pm \mathrm{U})$ ore in the Gawler Craton, South Australia. In: Porter, T.M. (Ed.), Hydrothermal Iron Oxide Copper-Gold \& Related Deposits: a Global Perspective, Australian Miner. Fund, Adelaide, vol. 3, pp. 119-146.

Hirata, W.K., Rigon, J.C., Kadekaru, K., Cordeiro, A.A.C., Meireles, E.A., 1982. Geologia Regional da Província Mineral de Carajás. In: 1st Simpósio de Geologia da Amazônia, Belém. (Proceedings). 
Huhn, S.R.B., 1992. Geologia, controle estrutural e gênese do depósito aurífero Babaçu, região de Rio Maria, sul do Pará (Master thesis). IG/UnB, 168 p.

Isotta, C.A.R., Carneiro, J.M., Kato, H.F., Barros, R.J.S., 1978. Projeto Província Estanífera de Rondônia, relatório final. In: MME, Convênio- DMPM-CPRM, vol. I, Il and III.

Issler, R.S., Andrade, A.R.F., Montalvão, R.M.G., Guimarães, G., Silva, G.G., Lima, M.I.C., 1974. Geologia da Folha SA.22 - Belém. Brasil, Departamento Nacional da Produção Mineral. Projeto RADAMBRASIL. Folha SA.22 - Belém. Rio de Janeiro. In: Levantamento de Recursos Naturais 5, pp. 7-182.

Juliani, C., Echeverri-Misas, C.M.E., Lagler, B., Usero, G., Fernandes, C.M.D., Monteiro, L.V.S., 2011. 1,87 Ga Au quartz-alunite and Cu-Mo-(Au) adularia sericite epithermal and $\mathrm{Au}-(\mathrm{Cu})$ porphyry mineralization in the Tapajós Gold Province, Amazonian craton. In: SGA Biennial Meeting Chile (CD-ROM).

Juliani, C., Fernandes, C.M.D., 2010. Well-preserved Late Paleoproterozoic volcanic centers in the São Félix do Xingu region, Amazonian Craton, Brazil. J. Volcanol. Geotherm. Res. 191, 167-179.

Juliani, C., Correa-Silva, R.H., Monteiro, L.V.S., Bettencourt, J.S., Nunes, C.M.D., 2002. The Batalha Au-Granite system-Tapajós Province, Amazonian Craton, Brazil: hydrothermal alteration and regional implication. Precambrian Res. 119, 225-256.

Juliani, C., Rye, R.O., Nunes, C.M.D., Snee, L.W., Corrêa-Silva, R.H., Monteiro, L.V.S., Bettencourt, J.S., Neumann, R., Alcover Neto, A., 2005. Paleoproterozoic volcanic-hosted quartz-alunite epithermal deposits in the Tapajós Gold Province, Amazonian Craton, Brazil. Chem. Geol. 215, 95-125.

Juliani, C., Carneiro, C.C., Carreiro-Araújo, S.A., Fernandes, C.M.D., Monteiro, L.V.S. Crósta, A.P., 2013. Estruturação dos arcos magmáticos paleoproterozóicos na porcão sul do Craton Amazônico: implicacõoes geotectônicas e metalogenéticas. In: Simpósio de Geologia da Amazônia, 13, Anais. SBG/Núcleo Norte, Belém, PA, Brasil (CD-ROM).

Juliani, C., Vasquez, M.L., Klein, E.L., Villas, R.N.N., Echeverri-Misas, C.M. Santiago, E.S.B., Monteiro, L.V.S., Carneiro, C. de C., Fernandes, C.M.D., User, G. 2014. Metalogênese da Província Tapajós. In: Silva, M.G., Rocha Neto, M.B. Jost, H., Kuyumjian, R.M. (Eds.), Metalogênese das Províncias Tectônicas Brasileiras, Programa Geologia do Brasil, Recursos Minerais, Serviço Geológico do Brasil, CPRM, pp. 229-263.

Klein, E.L., Fuzikawa, K., 2010. Origin of the $\mathrm{CO}_{2}$-only fluid inclusions in the Palaeoproterozoic Carará vein-quartz gold deposit, Ipitinga Auriferous District, SEGuiana Shield, Brazil: implications for orogenic gold mineralization. Ore Geol. Rev. 37, 31-40.

Klein, E.L., Rosa-Costa, L.T.R., 2003. Geology of quartz-vein gold deposits in the Ipitinga Auriferous District, northern Brazil, southeastern Guiana Shield. Géol. Fr. 2-3-4, 231-242.

Klein, E.L., Lafon, J.M., Harris, C., Brito, R.S.C., Vaconcelos, P., 2009. Fluid inclusion and isotopic constraints on the genesis of vein-quartz gold deposits of the Ipitinga Auriferous District, SE-Guiana Shield, Brazil. In: Rizzotto, G.J., Quadros, M.L.E.S. (Eds.), Contribuições à Geologia da Amazônia, vol. 6 pp. $15-42$.

Klein, E.L., Rosa-Costa, L.T., Vasquez, M.L., 2014. Metalogênese da borda oriental do Cráton Amazônico. In: Silva, M.G., Rocha Neto, M.B., Jost, H., Kuyumjian, R.M. (Eds.), Metalogênese das Províncias Tectônicas Brasileiras. CPRM, Belo Horizonte, pp. 171-194.

Lamarão, C.N., Dall'Agnol, R., Lafon, J.M., Lima, E.F., 2002. Geology, geochemistry, and $\mathrm{Pb}-\mathrm{Pb}$ zircon geochronology of the Paleoproterozoic magmatism of the Vila Riozinho, Tapajós Gold Province, Amazonian craton, Brazil. Prec. Res. 119, $189-223$.

Lamarão, C.N., Dall'Agnol, R., Pimentel, M., 2005. Nd isotopic composition of Paleoproterozoic volcanic and granitoid rocks of Vila Riozinho: implications for the crustal evolution of the Tapajos gold province, Amazon craton. J. South Am. Earth Sci. 18 (3-4), 277-292.

Leite Jr., W.B., 2002. A Suíte Intrusiva Santa Clara (RO) e a mineralização primária polimetálica ( $\mathrm{Sn}, \mathrm{W}, \mathrm{Nb}, \mathrm{Ta}, \mathrm{Zn}, \mathrm{Cu}$ e $\mathrm{Pb}$ ) associada (Ph.D. thesis). Instituto de Geociências, Universidade de São Paulo, São Paulo, SP, Brazil (in Portuguese).

Leite Jr., W.B., Payolla, b. L., Bettencourt, J.S., Dias, C.A.T., 2014. 138-1.39 A-type granites related to the evolution of the Rondonian-San Ignacio orogenic system, SW Amazonian Crato, Brazil: a geochemical overview. Comun. Geol. 101 (Especial I), 125-129.

Leite Jr., W.B., Oliveira, R.C.B., Tamborim, D.A.R., Payolla, B.L., Bettencourt, J.S., 2005. Geoquímica dos topázio granitos do stock Palanqueta, mina Bom Futuro, Rondônia: consideracões preliminares. In: Congresso Brasileiro de Geoquímica, 10, Porto de Galinhas, Pernambuco (CD-ROM).

Lenharo, S.L., 1998. Evolução magmática e modelo metalogenético dos granitos mineralizados da região de Pitinga, Amazonas, Brasil. São Paulo (Doctora thesis). Escola Politécnica, USP, 290 p.

Lima, M.V.G.R., 2010. Geologia e Geocronologia do Depósito Aurífero do Palito Província do Tapajós, Itaituba - Pa. Trabalho de conclusão de Curso (graduação em geologia), Instituto de Geociências UFPA, Faculdade de Geologia, Belém, 72 p. 180.

Lima, M.V.G.R., Santos, M.D., Lafon, J.M., 2010. Geologia e Geocronologia do Depósito Aurífero do Palito, Província do Tapajós, Itaituba - Pa. In: SBG, Congresso Brasileiro de Geologia, 45. Belém - PA.

Lindenmayer, Z.G., Fleck, A., Gomes, C.H., Santos, A.B.S., Caron, R., Paula, F. de C. Laux, J.H., Pimentel, M.M., Sardinha, A.S., 2005. Caracterização geológica do Alvo Estrela (Cu-Au), Serra dos Carajás, Pará. In: Marini, O.J. Ramos, B.W. Queiroz, E.T. (Eds.), Caracterização de Depósitos Minerais de Distritos Mineiros da Amazônia. DNPM-CT-Mineral-FINEP-ADIMB, Brasília, pp. 137-205.
Linnen, R.L., 1998. Depth of emplacement, fluid provenance and metallogeny in granitic terranes: a comparison of western Thailand with other tin belts. Miner. Deposita 33, 461-476.

Macambira, E.M.B., Ricci, P.S.F., Klein, E.L., 2006. Aspectos geológicos do garimpo de ouro do Mandi, Cumaru do Norte - sul do Pará. In: SBG, Simpósio de Geologia da Amazônia, 9, Resumos (CD-ROM).

Macambira, E.M.B., Vasquez, M.L., Ricci, P.S.F., 2007. Caracterização do domínio tectônico Santana do Araguaia - sudeste do Pará. In: SBG, Simp. Geol. Amaz., 10, Resumos Expandidos (CD-ROM).

Machado, N., Lindenmayer, D.H., Krough, T.E., Lindenmayer, Z.G., 1991. U-Pb geochronology of Archean magmatism and basement reactivation in the Carajás area, Amazon Shield, Brazil. Precambrian Res. 49, 329-354.

Mandetta, P., Veiga Jr., J.P., Oliveira, J.R., 1974. Reconhecimento geológico ao longo do rio Pitinga, afluente do rio Uatumã. Manaus. Companhia de Pesquisa de Recursos Minerais. Relatório interno, 31 p.

Martin, R.F., 2006. A-type granites of crustal origin ultimately result from opensystem fenitization-type reactions in an extensional environment. Lithos 91, $125-136$.

Melo, L.V., Villas, R.N., Faraco, M.T.L., Soares, J.W., 2003. Geological setting and mineralizing fluids of the Amapari gold deposit, Amapá state, Brazil. Géol. Fr. $2-3-4,243-255$.

Melo, G.H.C. de, 2014. Evolução temporal do depósito de oxido de ferro-cobre-ouro de Salobo, Província Mineral de Carajás (Master thesis). Geoscience Istitute, University of Campinas - UNICAMP.

Miguel-Jr, E., 2011. Controle Estrutural das mineralizações auríferas e idades U-Pb das rochas encaixantes ao longo do Lineamento Peru-Trairão: Província Aurífera de Alta Floresta, Mato Grosso (Master thesis). Geoscience Istitute, University of Campinas - UNICAMP.

Minuzzi, O.R.R., Bastos Neto, A.C., Pereira, V.P., Flores, J.A.A., 2006. O depósito criolítico maciço e o minério disseminado de criolita da mina Pitinga (Amazonas, Brasil). Rev. Bras. Geociências 36 (Suppl. vol.), 104-123.

Monteiro, L.V.S., Xavier, R.P., Carvalho, E.R., Hitzman, M.W., Johnson, C.A., Souza Filho, C.R., Torresi, I., 2008a. Spatial and temporal zoning of hydrothermal alteration and mineralization in the Sossego iron oxide-copper-gold deposit, Carajás Mineral Province, Brazil: paragenesis and stable isotope constraints. Miner. Deposita 43, 129-159.

Monteiro, L.V.S., Xavier, R.P., Hitzman, M.W., Juliani, C., Souza Filho, C.R., Carvalho, E.R., 2008b. Mineral chemistry of ore and hydrothermal alteration at the Sossego iron oxide-copper-gold deposit, Carajás Mineral Province, Brazil. Ore Geol. Rev. 34, 317-336.

Moreto, C.P.N., Monteiro, L.V.S., Xavier, R.P., Amaral, W.S., Santos, T.J.S., Juliani, C. Souza Filho, C.R., 2011. Mesoarchean (3.0 and $2.86 \mathrm{Ga}$ ) host rocks of the iron oxide-Cu-Au Bacaba deposit, Carajás Mineral Province: U-Pb geochronology and metallogenetic implications. Miner. Deposita 46, 789-811. http:// dx.doi.org/10.1007/s00126-011-0352-9.

Moreto, C.P.N., Monteiro, L.V.S., Xavier, R.P., Creaser, R.A., Dufrane, A., Tassinari, C.G., Sato, K., Kemp, A., Amaral, W.S., 2015a. Neoarchean and paleoproterozoic iron oxide-copper-gold events at the Sossego Deposit, Carajas Province, Brazil: ReOs and U-Pb geochronological evidence. Econ. Geol. 110, 809-835.

Moreto, C.P.N., Monteiro, L.V.S., Xavier, R.P., Creaser, R.A., DuFrane, A., Melo, G.H.C., Silva, M.A.D., Tassinari, C.C.G., Sato, K., 2015b. Timing of multiple hydrothermal events in the iron oxide-copper-gold deposits of the Southern Copper Belt, Carajás Province, Brazil. Miner. Deposita 50, 517-546.

Moura, M.A., 1998. O Maciço Granítico Matupá e o Depósito de Ouro Serrinha (MT): Petrologia, Alteração Hidrotermal e Metalogenia (Doctorate thesis). Instituto de Geociências, Universidade de Brasília, Brasília, 238 p.

Nogueira, A.C.R., Truckenbrodt, W., Pinheiro, R.V.L., 1995. Formação Águas Claras, Pré-Cambriano da Serra dos Carajás: redescrição e redefinição litoestratigráfica. In: Bol Mus Paraense Emílio Goeldi, Ciências Terra 7, pp. 177-277.

Nogueira, S.A.A., Bettencourt, J.S., Tassinari, C.G., 2000. Geochronology of the granitoid hosted Salamangone gold deposit, Lourenco district Amapá, Brazil. Rev. Bras. Geociências 30, 261-264.

Nunes, A.R., Costa, A.F.U., Silva, L.G., Quirino, L.F.B., 2007. Aplicação do método da polarização induzida nos arranjos gradient e dipolo-dipolo como ferramenta de suporte à identificação de extensões da mineraização aurífera no depósito Amapari. In: SBGf, Internacional Congress of the Brazilian Geophysical Society, 10. Abstracts.

Oliveira, C.G., 1993. Interação entre os processos de deformação, metamorfismo e mineralização aurífera durante a evolução da zona de cisalhamento de Diadema, sul do Pará (Doctorate thesis). UnB, p. 187.

Oliveira, C.G., Leonardos, O.H., 1990. Gold mineralization in the Diadema shear belt, northern Brazil. Econ. Geol. 85, 1034-1043.

Oliveira, C.G., Santos, R.V., 2003. Isotopic domains controlled by transtentional and transpressional sectors in the auriferous Diadema shear belt, northern Brazil. J. South Am. Earth Sci. 16, 513-522.

Oliveira, M.A., Dall'agnol, R., Althoff, F.J., Leite, A.A.S., 2009. Mesoarchean sanukitoid rocks of the Rio Maria Granite-Greenstone Terrane, Amazonian craton, Brazil. J. South Am. Earth Sci. 27 (2-3), 146-160.

Oliveira, M.A., Dall'agnol, R., Almeida, J.A.C., 2011. Petrology of the Mesoarchean Rio Maria suite and the discrimination of sanukitoid series. Lithos 127 (1-2), 192-209.

Paes de Barros, A.J., 1994. Contribuição a geologia e controle das mineralizações auríferas de Peixoto de Azevedo - MT (Master thesis). Instituto de Geociências, Universidade de São Paulo, São Paulo, 145 p.

Paes de Barros, A.J., 2007. Granitos da região de Peixoto de Azevedo - Novo Mundo 
e mineralizações auríferas relacionadas - Província Aurífera Alta Floresta (MT) (Doctorate thesis). Instituto de Geociências, Universidade Estadual de Campinas, Campinas, 154 p.

Pidgeon, R.T., Macambira, M.J.B., Lafon, J.M., 2000. Th-U-Pb isotopic systems and internal structures of complex zircons from an enderbite from the Pium Complex, Carajás Province, Brazil: evidence for the ages of granulite facies metamorphism and the protolith of the enderbite. Chem. Geol. 166, 159-171.

Pierosan, R., Lima, E.F., Nardi, L.V.S., Campos, C.P., Bastos Neto, A.C., Ferron, J.M.T.M., Prado, M., 2011a. Paleoproterozoic $(\sim 1.88 \mathrm{Ga})$ felsic volcanism of the Iricoumé Group in the Pitinga Mining District area, Amazonian Craton, Brazil: insights in ancient volcanic processes from field and petrologic data. An. Acad. Brasileira Ciências 83, 921-937.

Pierosan, R., Lima, E.F., Nardi, L.V.S., Bastos Neto, A.C., Campos, C.P., Ferron, J.M.T.M., Prado, M., 2011b. Geochemistry of Palaeoproterozoic volcanic rocks of the Iricoume Group, Pitinga Mining District, Amazonian craton, Brazil. Int. Geol. Rev. 53, 946-976.

Pimentel, M.M., 2001. Resultados geocronológicos do Projeto Promin Alta Floresta. UnB. Relatório Interno (Inédito), Brasília.

Pinheiro, R.V.L., Kadekaru, K., Soares, A.V., Freitas, C., Ferreira, S.N., Matos, F.M.V., 2013. Carajás, Brazil - a short tectonic review. In: 13th Simposio de geologia da Amazônia. Belém. (Proceedings).

Pollard, P.J., 1989a. Geochemistry of granites associated with tantalum and niobium mineralization. In: Möller, P., Cerný, P., Saupé, F. (Eds.), Lanthanides, Tantalum and Niobium. Springer-Verlag, Berlin, pp. 145-158.

Pollard, P., 1989b. Geologic characteristics and genetic problems associated with the development of granite-hosted deposits of tantalum and niobium. In: Möller, P., Cerný, P., Saupé, F. (Eds.), Lanthanides, Tantalum and Niobium. Springer-Verlag, Berlin, pp. 240-256.

Quadros, M.L.E.S., Rizzotto, G.J., 2007. Geologia e Recursos Minerais do Estado de Rondônia: Sistema de Informações Geográficas (SIG). Programa Geologia do Brasil (PGB), Integração, Atualização e Difusão de Dados da Geologia dos Brasil, Subprograma Mapas Geológicos Estaduais. CPRM - Serviço Geológico do Brasil, Porto Velho (CD-ROM).

Réquia, K., Stein, H., Fontboté, L., Chiaradia, M., 2003. Re-Os and Pb-Pb geochronology of the Archean Salobo iron oxide copper-gold deposit, Carajás Mineral Province, northern Brazil. Miner. Dep. 38, 727-738.

Rios, F.J., 1995. A jazida de wolframita de Pedra Preta, granito Musa (PA): estudo dos fluidos mineralizantes e isótopos estáveis de oxigênio em veios hidrotermais. Tese de doutorado, UFPA, Belém, 214 p.

Rios, F.J., Villas, R.N., Fuzikawa, K., Sial, A.N., Mariano, G., 1998. Isótopos de oxigênio e temperatura de formação dos veios mineralizados com wolframita da jazida Pedra Preta, sul do Pará. Rev. Bras. Geociências 28, 253-256.

Rios, F.J., Villas, R.N., Fuzikawa, K., 2003. Fluid evolution in the Pedra Preta wolframite ore deposit, Paleoproterozoic Musa Granite, eastern Amazon craton, Brazil. J. South Am. Earth Sci. 15, 787-802.

Rodrigues, R.M., 2012. Caracterização geológica e metalogenética do Depósito X1 Província Aurífera de Alta Floresta, Região de Matupá (MT) (Master thesis). Universidade Estadual de Campinas, Campinas, Brasil, 70 p.

Ronchi, L.H., Bastos Neto, A.C., Gedoz, S.C., Weber, M.L., Pereira, V.P., Andrek, M.A., 2011. A transição magmático-hidrotermal registrada por inclusões fluidas no albita granito de núcleo (Pitinga, Amazonas). In: Frantz, J.C., Marques, J.C., Jost, H. (Eds.), Contribuições à Metalogenia do Brasil. Instituto de Geociências, Porto Alegre, pp. 71-88.

Rosa, J.W.C., Rosa, J.W.C., Fuck, R.A., 2014. Geophysical structures and tectonic evolution of the southern Guyana shield, Brazil. J. South Am. Earth Sci. 52, 57-71.

Rosa-Costa, L.T., Lafon, J.M., Delor, C., 2006. Zircon geochronology and Sm-Nd isotopic study: further constraints for the Archean and Paleoproterozoic geodynamic evolution of the southeastern Guiana Shield, north of Brazil. Gondwana Res. 10, 277-300.

Rosa-Costa, L.T., Chaves, C.L., Klein, E.L., 2014. Geologia e recursos minerais da Folha Rio Araguari - NA. 22-Y-B. CPRM/Serviço Geol. Bras.

Santos, J.O.S., 2003. Geotectônica do Escudo das Guianas e Brasil-Central. In: Bizzi, L.A., Schobbenhaus, C., Vidotti, R.M., Gonçalves, J.H. (Eds.), Geologia, Tectônica e Recursos Minerais do Brasil. CPRM, Brasília, pp. 169-226.

Santos, M.D., Leonardos, O.H., Foster, R.P., Fallick, A.E., 1998. The lode-porphyry model as deduced from the Cumaru mesothermal granitoid-hosted gold deposit, Southern Para, Brazil. Rev. Bras. Geociências 28, 327-338.

Santos, J.O.S., Silva, L.C., Faria, M.S.G., Macambira, M., 1997. Pb-Pb single crystal evaporation isotopic study of the post-tectonic, sub-alkaline, A-type moderna granite (Mapuera Intrusive Granite), State of Roraima, northern Brazil. In: International Symposium on Granites and Associated Mineralizations (ISGAM), 2, Salvador, Bahia, Extended Abstracts and Program, pp. 273-275.

Santos, J.O.S., Hartmann, L.A., Gaudette, H.E., Groves, D.I., McNaugthon, N.J., Fletcher, L.R.A., 2000. New understanting of the Provinces of Amazon Craton based on Integration of Field Mapping and $\mathrm{U}-\mathrm{Pb}$ and $\mathrm{Sm}-\mathrm{Nd}$ geochronology. Gondwana Res. 3 (4), 453-488.

Santos, J.O.S., Hartmann, L.A., McNaugthon, N.J., Fletcher, I.R., 2002. Timing of mafic magmatism in the Tapajós Province (Brazil) and implications for the evolution of the Amazon Craton: evidence from baddeleyite and zircon U-Pb SHRIMP geochronology. J. South Am. Earth Sci. 15, 409-429.

Santos, R.D., Galarza, M.A., Oliveira, D.C., 2013. Geologia, geoquímica e geocronologia do Diopsídio-Norito Pium, Província Carajás. Bol. Mus. Para. Emílio Goeldi Ciências Nat. 8 (3), 355-382.

Sardinha, A.S., Barros, C.E. de M., Krymsky, M., 2006. Geology, geochemistry and
U-Pb geochronology of the Archean (2.74 Ga) Serra do Rabo granite stocks, Carajás Metallogenetic Province, northern Brazil. J. South Am. Earth Sci. 20, 327-339.

Serrato, A.A.A., 2014. Geocronologia e evolução do sistema hidrotermal do depósito aurífero de Juruena, Província Aurífera de Alta Floresta (MT), Brasil (Master thesis). Universidade Estadual de Campinas, Campimas, Brasil, 83 p.

Sillitoe, R.H., Hedenquist, J.W., 2003. Linkages between Volcanotectonic settings, ore-fluid compositions, and epithermal precious metal deposits. Soc. Econ. Geol. Special Publ. 10, 315-343.

Silva, M.G., Abram, M.B., 2008. Projeto metalogenia da Província Aurífera JuruenaTeles Pires, Mato Grosso. Serviço Geológico Brasileiro, CPRM, Goiânia, 212 p.

Simões, M.S., Almeida, M.E., Souza, S.G.H., Silva, D.P.B., Rocha, P.G., 2014. Characterization of the volcanic and hypabissal rocks of the Paleoproterozoic Iricoumé Group in the Pitinga region and Balbina Lake area, Amazonian Craton, Brazil: petrographic distinguishing features and emplacement conditions. J. Volcanol. Geotherm. Res. 286, 138-147.

Smith, M., Banks, D.A., Yardley, B.W.D., Boyce, A., 1996. Fluid inclusion and stable isotope constraints on the genesis of the Cligga Head Sn-W deposit, S.W. Eur. J. Mineral. 8, 961-974.

Sousa, C.S., Costa Neto, M.C., 2014. Programa Geologia do Brasil-PGB. Lourenço. Folha NA.22-V-D. Estado do Amapá. Carta Geológica. CPRM, Belém. Escala 1: 250.000 .

Souza, V.S., 2003. Evolução magmática e modelo metalogenético do sistema vulcanoplutônico estanífero Bom Futuro (RO) (Doctorate thesis). Instituto de Geociências, Universidade de Brasília, Brasília, DF, Brazil (in Portuguese).

Souza, V.S., Kotschoubey, B., 2005. Geologia e mineralizações auríferas do garimpo do Manelão, região do médio rio Bacajá (PA). In: Horbe, A.M.C., Souza, V.S. (Eds.), Contribuiçõoes à Geologia da Amazônia, vol. 4, pp. 151-163.

Souza, S.Z., Potrel, H., Lafon, J.M., Althoff, F.J., Pimentel, M.M., Dall'agnol, R., Oliveira, C.G., 2001. Nd, Pb and Sr isotopes of the Identidade Belt, an Archaean greenstone belt of the Rio Maria region (Carajas Province, Brazil): implications for the Archaean geodynamic evolution of the Amazonian Craton. Precambrian Res. 109 (3-4), 293-315.

Souza, V.S., Macambira, M.J.B., Kotschoubey, B., 2003. Idade de zircão do granito Felício Turvo, garimpo de ouro do Manelão, região do Bacajá (PA): implicações tectônicas. In: SBG, Simpósio de Geologia da Amazônia, 8. Resumos (CD-ROM).

Souza, J.P., Frasca, A.A.S., Oliveira, C.C., 2005. Geologia e Recursos Minerais da Província Mineral de Alta Floresta. Relatório Integrado. Serviço Geológico Brasileiro, CPRM, Brasília, 164 p.

Souza, V.S., Teixeira, L.M., Botelho, N.F., 2005. Datação U-Th-Pb de monazita hidrotermal e sua aplicação na geocronologia da mineralização de estanho em Zonas de Greisen do sistema granítico Palanqueta, Depósito do Bom Futuro (RO). Rev. Bras. Geociências 35 (1), 43-48.

Sparrenberger, I., 2003. Evolução da mineralização primária estanífera associada ao maciço granítico Santa Bárbara, Rondônia (Ph.D. thesis). Instituto de Geociências, Universidade de São Paulo, São Paulo, SP, Brazil (in Portuguese).

Stropper, J.L., Eberhardt, D.B., Alves, C.L., Sabóia, A.M., Martins, E.G., 2011. Geoquímica prospectiva da porção nordeste do Mato Grosso - sudeste do Cráton Amazonas. In: SBGq, Congresso Brasileiro de Geoquímica, vol. 13, pp. 1781-1784. Gramado, Abstracts.

Sun, S., Yu, J., 1992. Euhedral crystals of quartz in Ta-granite: eocrystal, not porphyroblastic. In: International Geological Congress, 29th, vol. 2. IUGS, Kyoto, Japan, p. 539. Abstracts.

Tallarico, F.H.B., 2003. O cinturão cupro-aurífero de Carajás, Brasil (Doctorate thesis). UNICAMP, 229 p.

Tallarico, F.H.B., McNaughton, N.J., Groves, D.I., Fletcher, I.R., Figueiredo, B.R., Carvalho, J.B., Rego, J.L., Nunes, A.R., 2004. Geological and SHRIMP II U-Pb constraints on the age and origin of the Breves $\mathrm{Cu}-\mathrm{Au}-(\mathrm{W}-\mathrm{Bi}-\mathrm{Sn})$ deposit, Carajás, Brazil. Miner. Deposita 39, 68-86.

Tallarico, F.H.B., Figueiredo, B.R., Groves, D.I., Kositcin, N., McNaughton, N.J., Fletcher, I.R., Rego, J.L., 2005. Geology and SHRIMP U-Pb geochronology of the Igarapé Bahia deposit, Carajás copper-gold belt, Brazil: an Archean (2.57 Ga) example of iron-oxide $\mathrm{Cu}-\mathrm{Au}-(\mathrm{U}-\mathrm{REE})$ mineralization. Econ. Geol. 100, 7-28.

Tassinari, C.C.G., Macambira, M.J.B., 1999. Geochronological provinces of the Amazonian Craton. Episodes 22, 174-182.

Tassinari, C.C.G., Macambira, M.J.B., 2004. A evolução tectônica do craton Amazônico. In: Matesso-Neto, V., Bartorelli, A., Carneiro, C.D.R., BrittoNeves, B.B. (Eds.), Geologia do Continente Sul-Americano. São Paulo, SP, Brazil, pp. $471-485$.

Tassinari, C.C.G., Mellito, M.K., Babinski, M., 2003. Age and origin of the Cu (Au-Mo$\mathrm{Ag}$ ) Salobo $3 \mathrm{~A}$ ore deposit, Carajás Mineral Province, Amazonian Craton, northern Brazil. Episodes 26, 2-9.

Tavares, F., 2015. Evolução Geotectônica do Nordeste da Província Carajás (PhD thesis). Universidade Federal do Rio de Janeiro.

Taylor, R.P., 1992. Petrological and geochemical characteristics of the Pleasant Ridge zinnwaldite-topaz granite, southern New Brunswick, and comparisons with other topaz-bearing felsic rocks. Can. Mineral. 30, 895-921.

Taylor Jr., H.P., 1997. Oxygen and hydrogen isotope relationships in hydrothermal mineral deposits. In: Barnes, H.L. (Ed.), Geochemistry of Hydrothermal Ore Deposits, third ed. Wiley, New York, pp. 229-302.

Taylor, R.P., Fallick, A.E., 1997. The evolution of fluorine-rich felsic magmas: source dichotomy, magmatic convergence and the origins of topaz granite. Terra Nova 9, 105-108.

Teixeira, R.V., 2015. Rochas hospedeiras e controle estrutural da mineralização aurífera do depósito Peteca, região de Flor da Serra - MT, na Província Aurífera 
de Alta Floresta. Trabalho de Conclusão de Curso, Universidade Estadual de Campinas.

Teixeira, W., Tassinari, C.C.G., Cordani, U.G., Kawashita, K., 1989. A review of the geochronology of the Amazonian Craton: tectonic implication. Precambian Res. 42, 213-227.

Teixeira, N.P., Bello, R.M. da S., Bettencourt, J.S., 2002a. Inclusões fluidas do maciç granítico Antônio Vicente, Suite Intrusiva Velho Guilherme, Província Estanífera do Sul do Pará. Rev. Bras. Geociências 32 (1), 135-146.

Teixeira, N.P., Bettencourt, J.S., Moura, C.A.V., Dall'Agnol, R., Macambira, E.M.B. 2002b. Archean crustal sources for Paleoproterozoic tin-mineralized granites in the Carajás Province, SSE Pará, Brazil: Pb-Pb geochronology and Nd isotope geochemistry. Precambrian Res. 119, 257-275.

Teixeira, J.B.G., Lindenmayer, Z.G., Silva, M.G., 2010. Depósitos de Óxido de Fe, Cu-Au de Carajás. In: Brito, R.S.C., Silva, M.G., Kuyumjian, R.M. (Eds.), Modelos de depósitos de cobre do Brasil e sua resposta ao intemperismo, first ed. CPRM Brasilia, pp. 15-48.

Teixeira, W., Geraldes, M.C., Matos, R., Ruiz, A.S., Saes, G., Vargas-Matos, G., 2010 A review of the tectonic evolution of the Sunsás belt, SW Amazonian Craton. J. South Am. Earth Sci. 29, 47-60.

Teixeira, N.A., Ganade, C.E., Matos, F.M.V., Campos, L.D., Carvalho, M.T.N., 2015. Alkaline porphyry copper deposits and Iocg - what is the link?. In: Simpósio de Geologia da Amazônia, 14, SBG/NO (CD-ROM).

Thomas, R., Webster, J.D., Rhede, D., Seifert, W., öster, H.-J., Heinrich, W., Davidson, P. 2006. The transition from peraluminous to peralkaline granite melts: evidence from melt inclusions and accessory minerals. Lithos 91, 137-149.

Tokashiki, C. do C., Juliani, C., Monteiro, L.V.S., Echeverri-Misas, C.M., Aguja, M.A. Arrais, L.B., 2015. Eventos vulcânicos de 1,97 Ga com mineralizações de ouro epitermais low- e intermediate sulfidation na porção sul da Província Mineral Do Tapajós (PA). In: Gorayeb, P.S. de S., Lima, A.M.M. de (Eds.), Contribuições à Geologia da Amazônia, SBG-NN, vol. 9, pp. 119-138.

Torresi, I., Bortholoto, D.F.A. Xavier, R.P. Monteiro, L.V.S., 2012. Hydrothermal alteration, fluid inclusions and stable isotope systematics of the Alvo 118 iron oxide-copper-gold deposit, Carajás Mineral Province (Brazil): implications for ore genesis. Miner. Deposita 47, 299-323.

Trevisan, V.G., 2015. Estudo comparativo entre mineralizações filonares de $\mathrm{Au} \pm \mathrm{Cu}$ e Au + metais de base do setor leste da Província de Alta Floresta (MT), Cráton Amazônico (Master thesis). Universidade Estadual de Campinas, 129 p.
Usero, G., Juliani, C., Bello, R.M.S., Echeverri-Misas, C.M., Tommasini, D., Monteiro, L.V.S., 2011. Estudo das Inclusões Fluidas da Mineralização Paleoproterozóica de $\mathrm{Au}-(\mathrm{Cu})$ do Tipo Pórfiro do Palito, Província Aurífera do Tapajós (PA). In: Frantz, J.C., Marques, J.C., Jost, H. (Eds.), Contribuições à Metalogenia do Brasil. Porto Alegre, vol. 1. UFRGS/IG, pp. 111-128.

Vasquez, M.L., Macambira, M.J.B., Armstrong, R.A., 2008a. Zircon geochronology of granitoids from the western Bacajá domain, southeastern Amazonian craton, Brazil: Neoarchean to Orosirian evolution. Precambrian Res. 161, 279-302.

Vasquez, M.L., Rosa-Costa, L.R. Silva, C.G., Ricci, P.F., Barbosa, J.O., Klein, E.L., Lopes, E.S., Macambira, E.B., Chaves, C.L., Carvalho, J.M., Oliveira, J.G., Anjos, G.C. Silva, H.R., 2008b. Geologia e Recursos Minerais do Estado do Pará: Sistema de Informações Geográficas - SIG: Texto Explicativo dos Mapas Geológico e Tectônico e de Recursos Minerais do Estado do Pará. In: Vasquez, M.L., RosaCosta, L.T. (Eds.), Escala 1:1.000.000. CPRM, Belém, 329 p.

Veiga Jr., J.P., Nunes, A.C.B., Fernandes, A.S., Amaral, J.E., Pessoa, M.R., Cruz, S.A.S., 1979. Projeto Sulfetos de Uatumã. Relatório Final. Companhia de Pesquisa de Recursos Minerais $7 \mathrm{v}$, Manaus.

Villas, R.N., Santos, M.D., 2001. Gold deposits of the Carajás Mineral Province: deposit types and metallogenesis. Miner. Deposita 36, 300-331.

Wirth, K.R., Gibbs, A.K., Olszewski Jr., W.J., 1986. U-Pb ages of zircons from the Grão Pará Group and Serra dos Carajás granite, Pará, Brasil. Rev. Bras. Geociências 16, 195-200.

Xavier, R.P., Araújo, C.E.G. de, Dreher, A.M., Nunes, A.R., Rego, J.L. 2005. Fluid evolution in the Paleoproterozoic intrusion-related Breves $\mathrm{Cu}-\mathrm{Au}-(\mathrm{Mo}-\mathrm{W}-\mathrm{Bi}-\mathrm{Sn})$ deposit, Carajás Mineral Province, northern Brazil. In: Horbe, A.M.C., Souza, W.S. (Eds.), Contribuição à Geologia da Amazônia, SBG-NN, vol. 4, pp. 129-137.

Xavier, R.P., Wiedenbeck, M., Trumbull, R.B., Dreher, A.M., Monteiro, L.V.S., Rhede, D., Araújo, C.E.G., Torresi, I., 2008. Tourmaline B-isotopes fingerprint marine evaporites as the source of high-salinity ore fluids in iron oxide-coppergold deposits, Carajás Mineral Province (Brazil). Geology 36, 743-746.

Xavier, R.P., Monteiro, L.V.S., Moreto, C.P.N., Pestilho, A.L.S., Melo, G.H.C., Silva, M.A.D. da, Aires, B., Ribeiro, C., Freitas e Silva, F.H., 2012. The iron oxide copper-gold systems of the Carajás Mineral Province. In: Hedenquist, J. Harris, M., Camus, F. (Eds.), SEG Special Publication 16, Geology and Genesis of Major Copper Deposits and Districts of the World: a Tribute to Richard H. Sillitoe, first ed., vol. 1. Society of Economic Geologists, Inc., Littleton, pp. 433-454. 